This renort was crepared as an accossn tof work soonsored by an azgency of the United Slates Governnient, watranty, exprisss of imolied

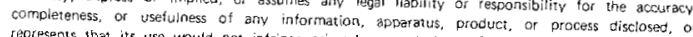

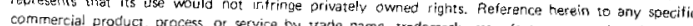

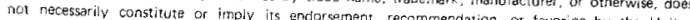

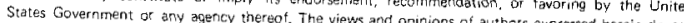

\title{
RAFT RIVER MONITOR WELL POTENTIOMETRIC HEAD RESPONSES AND WATER QUALITY AS RELATED TO THE CONCEPTUAL GROUND-WATER FLOW SYSTEM
}

\author{
David W. Allman \\ Julie A. Tullis \\ Max R. Dolenc \\ Thomas L. Thurow \\ Piotr A. Skiba
}

Published September 1982

EG\&G Idaho, Inc. Idaho Falls, Idaho 83415

Prepared for the

U.S. Department of Energy Idaho Operations Office Under DOE Contract No. DE-AC07-76ID01570 


\section{DISCLAIMER}

This report was prepared as an account of work sponsored by an agency of the United States Government. Neither the United States Government nor any agency Thereof, nor any of their employees, makes any warranty, express or implied, or assumes any legal liability or responsibility for the accuracy, completeness, or usefulness of any information, apparatus, product, or process disclosed, or represents that its use would not infringe privately owned rights. Reference herein to any specific commercial product, process, or service by trade name, trademark, manufacturer, or otherwise does not necessarily constitute or imply its endorsement, recommendation, or favoring by the United States Government or any agency thereof. The views and opinions of authors expressed herein do not necessarily state or reflect those of the United States Government or any agency thereof. 


\section{DISCLAIMER}

Portions of this document may be illegible in electronic image products. Images are produced from the best available original document. 


\section{ACKNOWLEDGMENTS}

The authors are indebted to several EG\&G personnel for their assistance in producing this report. Without the assistance of Lee Large in managing the Raft River hydrologic data, this report would not have been possible. Assistance and comments are also appreciated from Dennis Goldman Tony Allen, Brent Russell, Bruce Wiersma, and Lorie Cahn. 


\section{WELL DESIGNATIONS}

Well names are used profusely throughout this report, often in an abbreviated form. For purposes of clarification, the abbreviation, well name, use, and special designations are listed below.

$\begin{array}{lll}\text { RRGE-1 } & \text { Raft River Geothermal Exploratory-1 } & \text { Production } \\ \text { RRGE-2 } & \text { Raft River Geothermal Exploratory-2 } & \text { Production } \\ \text { RRGE-3 } & \text { Raft River Geothermal Exploratory-3 } & \text { Production } \\ \text { RRGI-4a } & \text { Raft River Geothermal Injection-4 } & \text { Injection } \\ \text { RRGP-4a } & \text { Raft River Geothermal Production-4 } & \text { Production } \\ \text { RRGP-5 } & \text { Raft River Geothermal Production-5 } & \text { Production } \\ \text { RRGP-5A } & \text { Raft River Geothermal Production-5 } & \text { Casing to 456 m } \\ \text { RRGP-5B } & \text { Raft River Geothermal Production-5 } & \text { Cased to 1034 m } \\ \text { RRGP-5C } & \text { Raft River Geothermal Production-5 } & \text { Cased to 1371 m } \\ \text { RRGI-6 } & \text { Raft River Geothermal Injection-6 } & \text { Injection } \\ \text { RRGI-7 } & \text { Raft River Geothermal Injection-7 } & \text { Injection } \\ & & \\ \text { MW-1 } & \text { Monitor Well-1 } & \text { Monitor } \\ \text { MW-2 } & \text { Monitor Well-2 } & \text { Monitor } \\ \text { MW-3 } & \text { Monitor Well-3 } & \text { Monitor } \\ \text { MW-4 } & \text { Monitor Well-4 } & \text { Monitor } \\ \text { MW-5 } & \text { Monitor Well-5 } & \text { Monitor } \\ \text { MW-6 } & \text { Monitor Well-6 } & \text { Monitor } \\ \text { MW-7 } & \text { Monitor Well-7 } & \text { Monitor } \\ & & \\ \text { USGS-2 } & \text { U.S. Geological Survey-2 } & \text { Monitor } \\ \text { USGS-3 } & \text { U.S. Geological Survey-3 } & \text { Monitor } \\ \text { BLMc } & & \\ \text { BLM offset } & \text { Bureau of Land Management } & \text { Monitor } \\ \text { Crook } & \text { U.S. Geological Survey well } & \text { Monitor } \\ \text { Crook domestic } & \text { Private hot well } & \text { Greenhouse } \\ \text { PW-3 } & \text { Private domestic well } & \text { Domestic } \\ \text { PW-5 } & \text { Pit Well-3 } & \text { Monitor } \\ & \text { Pit Well-5 } & \text { Monitor }\end{array}$

\footnotetext{
a. RRGI-4 was originally drilled to $2840 \mathrm{ft}$ to test as an injection well. The well was later deepened to use as a production well, and was designated RRGP-4.

b. Well RRGP-5 is designated according to the depth of casing or liner. Prior to the initial production casing, the well was referred to as RRGP-5A. After drilling adjacent to the original Leg A and setting casing, the well is referred to as RRGP-5B. After setting a 7-in. liner and hydraulically fracturing the well, it is referred to as RRGP-5C. Where no letter is used, an areal designation is inferred.

c. Old well on the site of a spring; monitored by a weir.

d. Well $5 \mathrm{~A}$ of 3 pit monitoring wells.
} 


\section{CONTENTS}

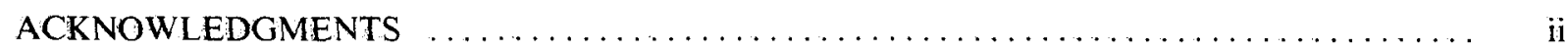

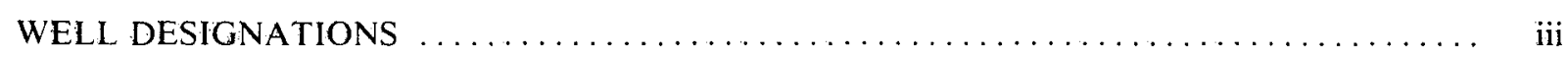

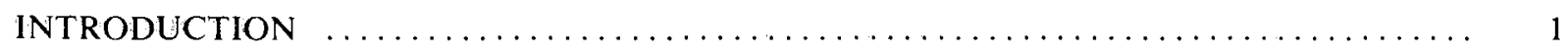

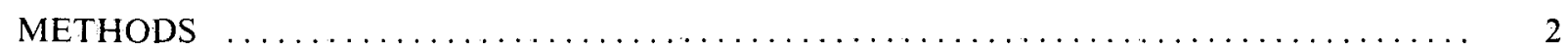

PRODUCTION-INJECTION TESTING $\ldots \ldots \ldots \ldots \ldots \ldots \ldots \ldots \ldots \ldots \ldots \ldots \ldots \ldots \ldots \ldots \ldots$

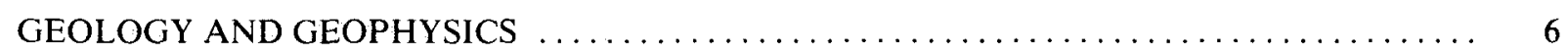

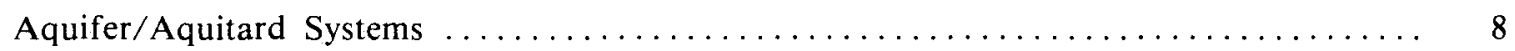

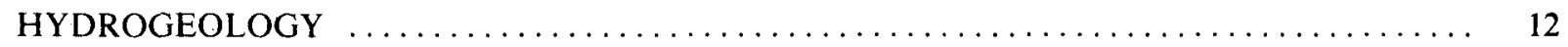

SHALLOW AQUIFER HYDROLOGY $\ldots \ldots \ldots \ldots \ldots \ldots \ldots \ldots \ldots \ldots \ldots \ldots \ldots \ldots \ldots \ldots \ldots \ldots \ldots \ldots$

Monitor Well Potentiometric Head Responses $\ldots \ldots \ldots \ldots \ldots \ldots \ldots \ldots \ldots \ldots \ldots \ldots \ldots \ldots$

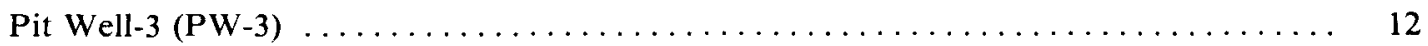

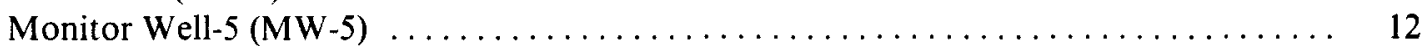

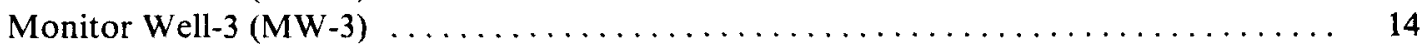

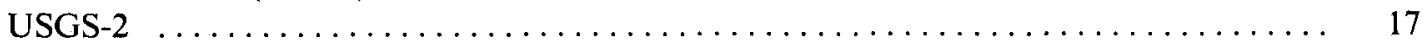

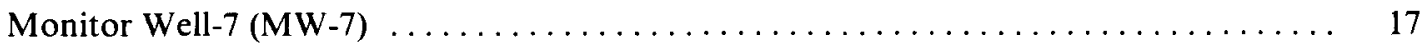

Pit Well-5 (PW-5) ................................. 20

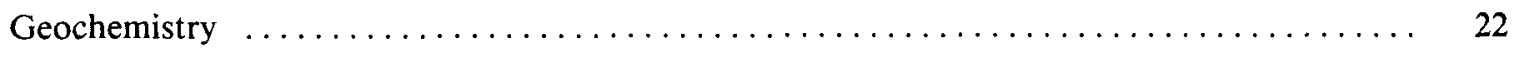

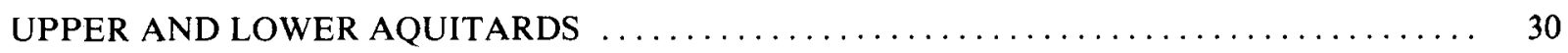

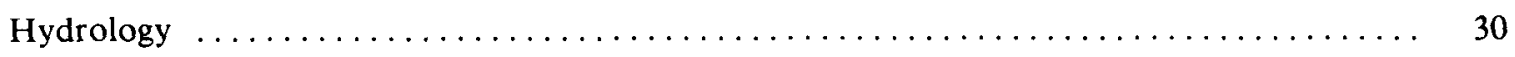

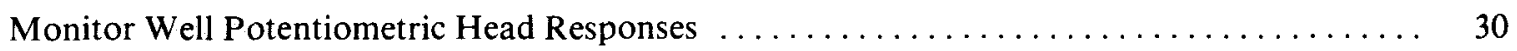

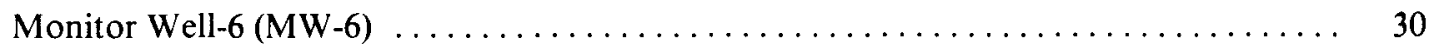

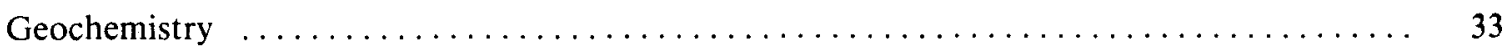

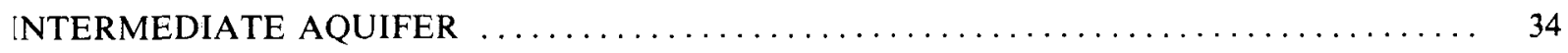

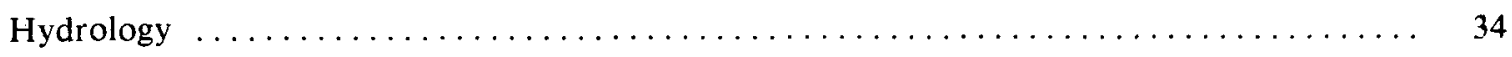

Monitor Well Potentiometric Head Responses $\ldots \ldots \ldots \ldots \ldots \ldots \ldots \ldots \ldots \ldots \ldots \ldots \ldots$

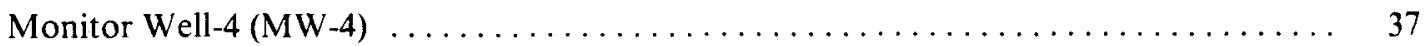

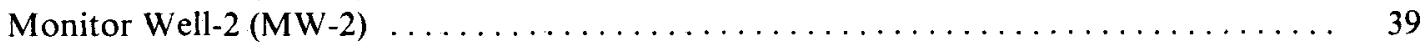

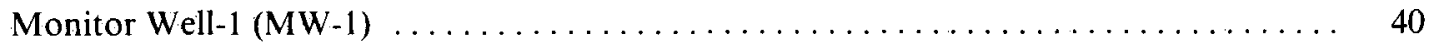

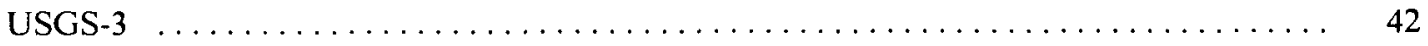

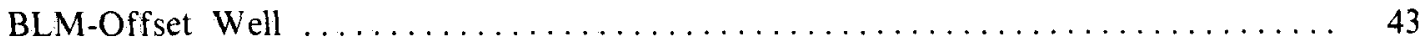

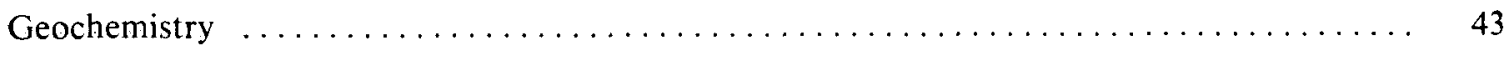


GEOTHERMAL AQUITARD/AQUIFER $\ldots \ldots \ldots \ldots \ldots \ldots \ldots \ldots \ldots \ldots \ldots \ldots \ldots \ldots \ldots \ldots \ldots \ldots \ldots$

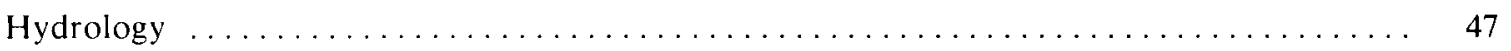

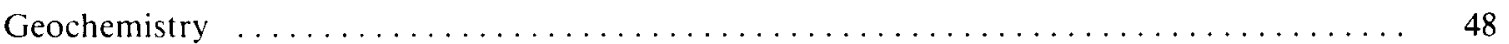

METAMORPHIC AND BASEMENT GEOTHERMAL AQUIFER $\ldots \ldots \ldots \ldots \ldots \ldots \ldots \ldots$

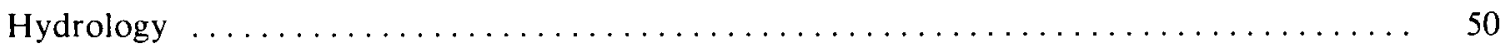

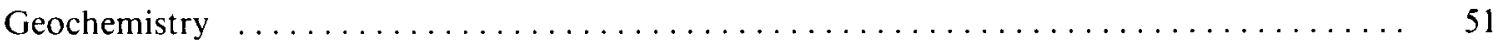

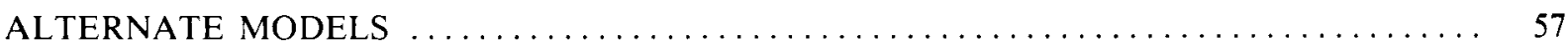

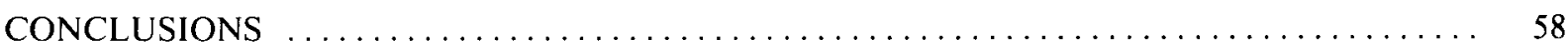

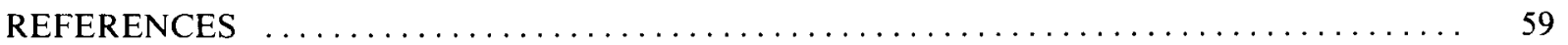

\section{FIGURES}

1. Location and depth of Raft River geothermal and monitor wells in addition to the

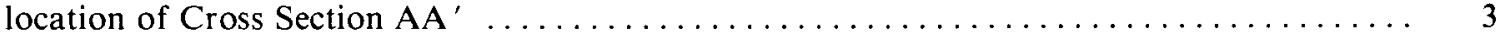

2. Raft River Valley and major structural features adjoining the valley $\ldots \ldots \ldots \ldots \ldots \ldots \ldots$

3. A recent interpretation of the geologic structure $\ldots \ldots \ldots \ldots \ldots \ldots \ldots \ldots \ldots \ldots \ldots$

4. Geologic and gravity map of the southern Raft River Valley $\ldots \ldots \ldots \ldots \ldots \ldots \ldots \ldots \ldots$

5. Cross Section $\mathrm{AA}^{\prime}$ of conceptual ground-water flow system $\ldots \ldots \ldots \ldots \ldots \ldots \ldots \ldots \ldots$

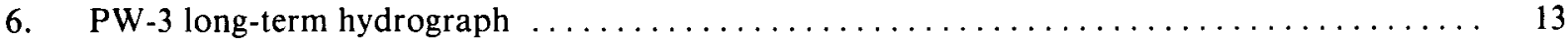

7. Hydrographs for PW-3, MW-3, -5, USGS-2, and injection rates for RRGI-6 and -7

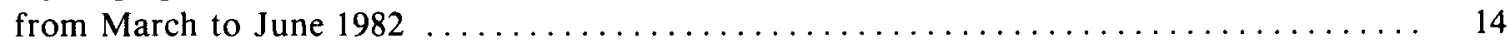

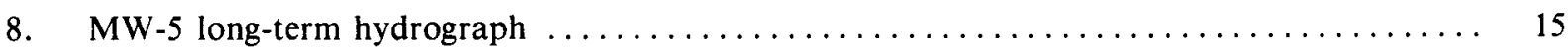

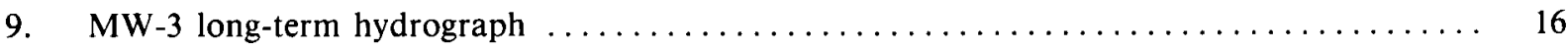

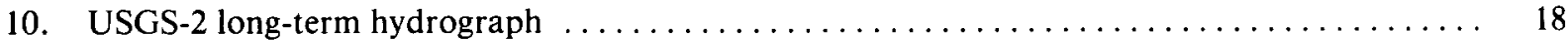

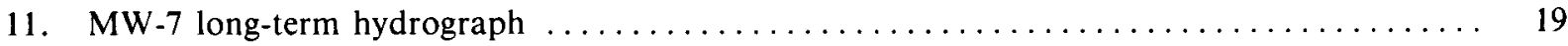

12. Hydrographs for MW-7, $-6, \mathrm{PW}-5$, and injection rates for RRGI-6 and -7 from

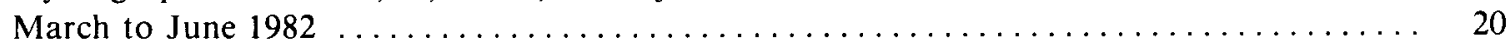

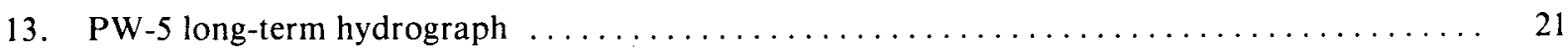

14. Specific conductance of water samples collected from selected wells at the

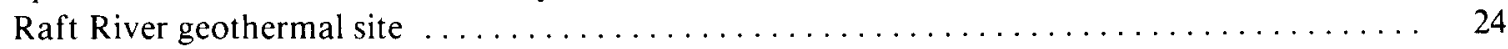

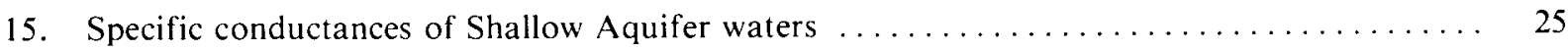




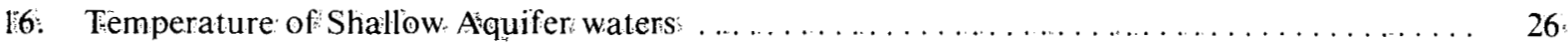

17. Cross Section AA: depicting the conceptualized temperature $\left({ }^{\circ} \mathrm{C}\right)$ distribution $\ldots \ldots \ldots \ldots .27$

18: Shut-in temperature profiles for Raft River mønitor wells $\ldots \ldots \ldots \ldots \ldots \ldots \ldots \ldots \ldots 28$

19. Cross Section $\mathrm{AA}$ ! depicting the conceptualized specific conductance $(\mu \mathrm{S})$ distribution $\ldots \ldots .29$

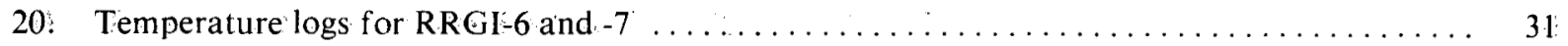

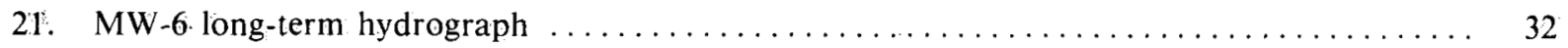

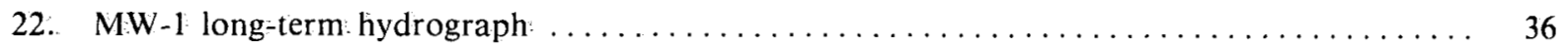

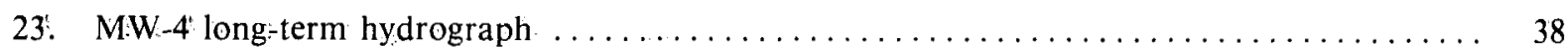

24. Hydrographs for MW-2, -4, and injection rates for RRGI-6 and -7 from March to June $1982 \ldots 39$

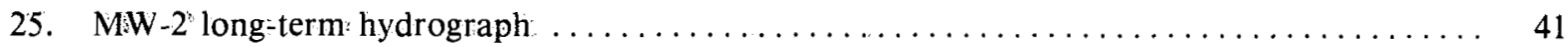

26. Hydrographs for MW-1, USGS-3, BLM offset and injection rates for

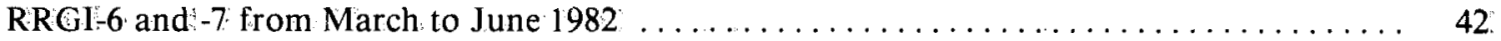

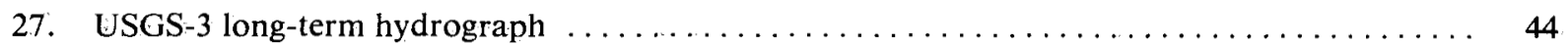

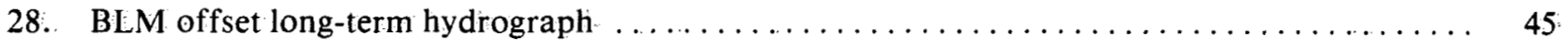

29. Isotherms for wellhead temperatures $\ldots \ldots \ldots \ldots \ldots \ldots \ldots \ldots \ldots \ldots \ldots \ldots \ldots \ldots \ldots$

30. Potentiometric surface for production wells $\ldots \ldots \ldots \ldots \ldots \ldots \ldots \ldots \ldots \ldots \ldots \ldots \ldots \ldots \ldots$

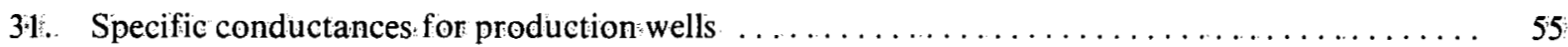

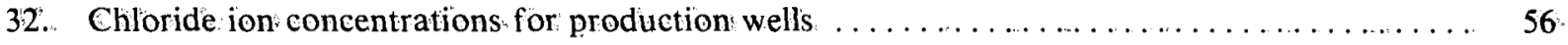

\section{TABLES}

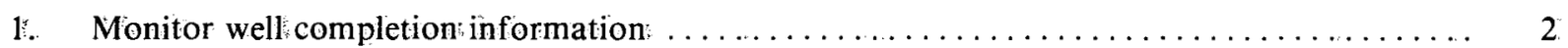

2. Major production and injection tests from 1978 through $1982(>80 \mathrm{~h}) \ldots \ldots \ldots \ldots \ldots \ldots . \quad 4$

3. Selected physical and chemical eharacteristics of well waters $\ldots \ldots \ldots \ldots \ldots \ldots \ldots \ldots \ldots \ldots$ 


\section{RAFT RIVER MONITOR WELL POTENTIOMETRIC HEAD RESPONSES AND WATER QUALITY AS RELATED TO THE CONCEPTUAL GROUND-WATER FLOW SYSTEM}

\section{INTRODUCTION}

In 1963, the Idaho Department of Water Resources (IDWR) declared the Raft River Basin a critical ground-water area and restrained further ground-water development. Therefore, with the inception of the Raft River geothermal program, concerns were identified pertaining to protection of the quality and quantity of the limited water supply in this region. Modeling of the Shallow Aquifers by the United States Geological Survey (USGS) indicated that it would take 100 years before projected rates of geothermal production would affect the irrigation and culinary water supply in the valley. 1 However, little is known of interactions between the Shallow and Intermediate depth Aquifers. Concern exists that high pressure injection at a depth of $517 \mathrm{~m}$, into the Intermediate Aquifer, could adversely affect nearby irrigation wells in the Shallow Aquifer. A groundwater monitoring program was established by the Department of Energy (DOE) to assess this concern.
Ground-water monitoring near the Raft River site was initiated in 1974 by the IDWR. This effort consisted of semiannual chemical sampling of 22 irrigation wells near the Raft River geothermal development area. This program yielded useful baseline chemical data; however, several problems were inherent. For example, access to water pumped from the wells is limited to the irrigation season (April through September). All the wells are not continuously pumped; thus, some wells that are sampled one season cannot be sampled the next. In addition, information on well construction, completion, and production is often unreliable or not available. Due to these problems, a joint decision between the IDWR and DOE was reached in 1976 to supplement these data by establishing a series of monitor wells in the proposed geothermal withdrawal and injection area. These wells were to be located and designed to provide data necessary for evaluating and predicting the impact of geothermal development on the Shallow Aquifer system. 


\section{METHODS}

The monitor wells were completed during 1978 : They were constructed such that the Shallow. Aquifer, used as a: source for irrigation water and the Epper Aquitard could be monitored. The location of the wells emphasized monitoring in areas of the well field where impacts associated with the geothermal development were most likely: (e.g., near the injection: wells). Seven monitor wells were established (MW-1 to -7). These, in addition to other existing wells in the area [including two USGS exploratory wells (USGS-2 and -3), a USGS BLM of set well near the BLM well and two additional wells Pit Well-3 (PW-3) and (PW-5)] form the nucleus of the injection monitoring program. The locations of the production and injection wells and each well in the monitor network are in Figure 1. Information on the completion characteristics of the monitor wells ${ }^{2}$ is presented in Table 1.

Each of the monitor wells, with the exceptions of PW-3 and -5 , is equipped with either a digiquartz pressure transducer or a Steven's water level recorder. These: instruments provide discrete and continuous records; respectively; of fluctuations in the potentiometric head in each well. To verify that the Steven's: water level recorders are functioning properly, wells equipped with these instruments are usually checked every 2 days by measuring depth to water via the wetted tape method: Data for PW-3 and -5 are also collected using the wetted tape method. During productioninjection tests the depth to water is measured. daily.

Water samples for chemical analyses are periodically collected from the monitor wells, the sample schedule being determined by the timing and extent of production-injection testing and the budgetary constraints for the particular fiscal year. The MW-1, -2, USGS-3, and Crook thermal wells have potentiometric surfaces above the land surface: Samples from these wells are collected using artesian flow. The remaining monitor wells are sampled using submersible pumps. Wells are generally purged of one wellbore volume before samples are collected:

Table 1. Monitor well completion information

\begin{tabular}{|c|c|c|c|c|c|c|c|}
\hline \multirow{3}{*}{$\begin{array}{l}\begin{array}{c}\text { Well: } \\
\text { Number }\end{array} \\
\text { MW-1: }\end{array}$} & \multirow{3}{*}{$\begin{array}{c}\begin{array}{c}\text { Elevation } \\
(\mathrm{m})^{:}\end{array} \\
1475^{\prime}\end{array}$} & \multirow{3}{*}{$\begin{array}{c}\begin{array}{c}\text { Well } \\
\text { Depth } \\
(\mathrm{m})\end{array} \\
399:\end{array}$} & \multirow{2}{*}{\multicolumn{2}{|c|}{ Casing }} & \multirow{3}{*}{ Perforations: } & \multicolumn{2}{|c|}{$\begin{array}{c}\text { Temperature } \\
\left({ }^{\circ} \mathrm{C}\right)\end{array}$} \\
\hline & & & & & & Surface & Bottom Hole \\
\hline & & & $\begin{array}{l}25 \mathrm{~cm} \text { diameter: } \\
15 \mathrm{~cm} \text { diameter: }\end{array}$ & $\begin{array}{c}0 \mathrm{~m} \text { to } 37 \mathrm{~m} \\
37 \mathrm{~m} \text { to } 369 \mathrm{~m}\end{array}$ & & 80 & - \\
\hline$M W=2$ & 1474 & 1.74: & $20 \mathrm{~cm}$ diameter: & $0 \mathrm{~m}$ to $166 \mathrm{~m}$ & $154 \mathrm{~m}$ to $166 \mathrm{~m}$ & 58 & 106 \\
\hline MW-3 & 1472 & 153 & $\begin{array}{l}30 \mathrm{~cm} \text { diameter: } \\
20 \mathrm{~cm} \text { diameter: }\end{array}$ & $\begin{array}{l}0 \mathrm{~m} \text { to } 61 \mathrm{~m} \\
61 \mathrm{~m} \text { to. } 153^{\circ} \mathrm{m}\end{array}$ & 50 slots between $140 \mathrm{~m}$ and $153^{\circ} \mathrm{m}$ & 24 & $71:$ \\
\hline MW-4: & 1468 : & 305 & $\begin{array}{l}25 \mathrm{~cm} \text { diameter: } \\
20 \mathrm{~cm} \text { diameter: }\end{array}$ & $\begin{array}{r}0 \mathrm{~m} \text { to } 171 \mathrm{~m} \\
171 \mathrm{~m} \text { to } 254 \mathrm{~m}\end{array}$ & 105 slots between $225 \mathrm{~m}$ and $254 \mathrm{~m}$ & 20 & 97 \\
\hline$M W-5$ & 1466 & 152 & $\begin{array}{l}30 \mathrm{~cm} \text { diameter: } \\
20 \mathrm{~cm} \text { diameter: }\end{array}$ & $\begin{array}{c}0 \mathrm{~m} \text { to } 61 \mathrm{~m} \\
61 \mathrm{~m} \text { to } 136 \mathrm{~m}\end{array}$ & 54 slots between $124 \cdot \mathrm{m}$ and 136 & 13 & 28 \\
\hline$M W-6$ & 1469 & 311 & $\begin{array}{l}25 \mathrm{~cm} \text { diameter: } \\
15 \mathrm{~cm} \text { diameter: }\end{array}$ & $\begin{array}{c}0 \mathrm{~m} \text { to } 46 \mathrm{~m} \\
46 \mathrm{~m} \text { to } 274 \mathrm{~m}\end{array}$ & None. & 11 & 44 \\
\hline MW-7 & 1474 & $152 \%$ & $\begin{array}{l}30 \mathrm{~cm} \text { diameter: } \\
30 \mathrm{~cm} \text { diameter: }\end{array}$ & $\begin{array}{l}0 \mathrm{~m} \text { to } 61 \mathrm{~m} \\
61 \mathrm{~m} \text { to } 152 \mathrm{~m}\end{array}$ & 50 slots between $140 \mathrm{~m}$ and $152 \mathrm{~m}$ & 20 & 35 \\
\hline USGS:2: & 1473 & 244 & $10 \mathrm{~cm}$ diameter: & $0 \mathrm{~m}$ to $64 \mathrm{~m}$ & None. & 28 & 59 \\
\hline USGS:3: & 1486 & 434 & $10 \mathrm{~cm}$ diameter: & $0 \mathrm{mto} 60 \mathrm{~m}$ & None & 77 & $89 ?$ \\
\hline PW-3 & $1470^{\circ}$ & 26 & $10 \mathrm{~cm}$ diameter: & $0 \mathrm{~m} / 017^{t} \mathrm{~m}$ & None & - & 一 \\
\hline PW-5 & $1490^{z}$ & 28 & $\begin{array}{l}15 \mathrm{~cm} \text { diameter: } \\
10 \mathrm{~cm} \text { diameter: }\end{array}$ & $\begin{array}{l}0 \mathrm{~m} \text { to } 17 \mathrm{~m} \\
17 \mathrm{mto} 26 \mathrm{~m}\end{array}$ & $17 \mathrm{mt} 1026 \mathrm{~m}$ & - & - \\
\hline BLM Offset: & 1500 & 123 & Not available: & 一. & - & - & - \\
\hline
\end{tabular}




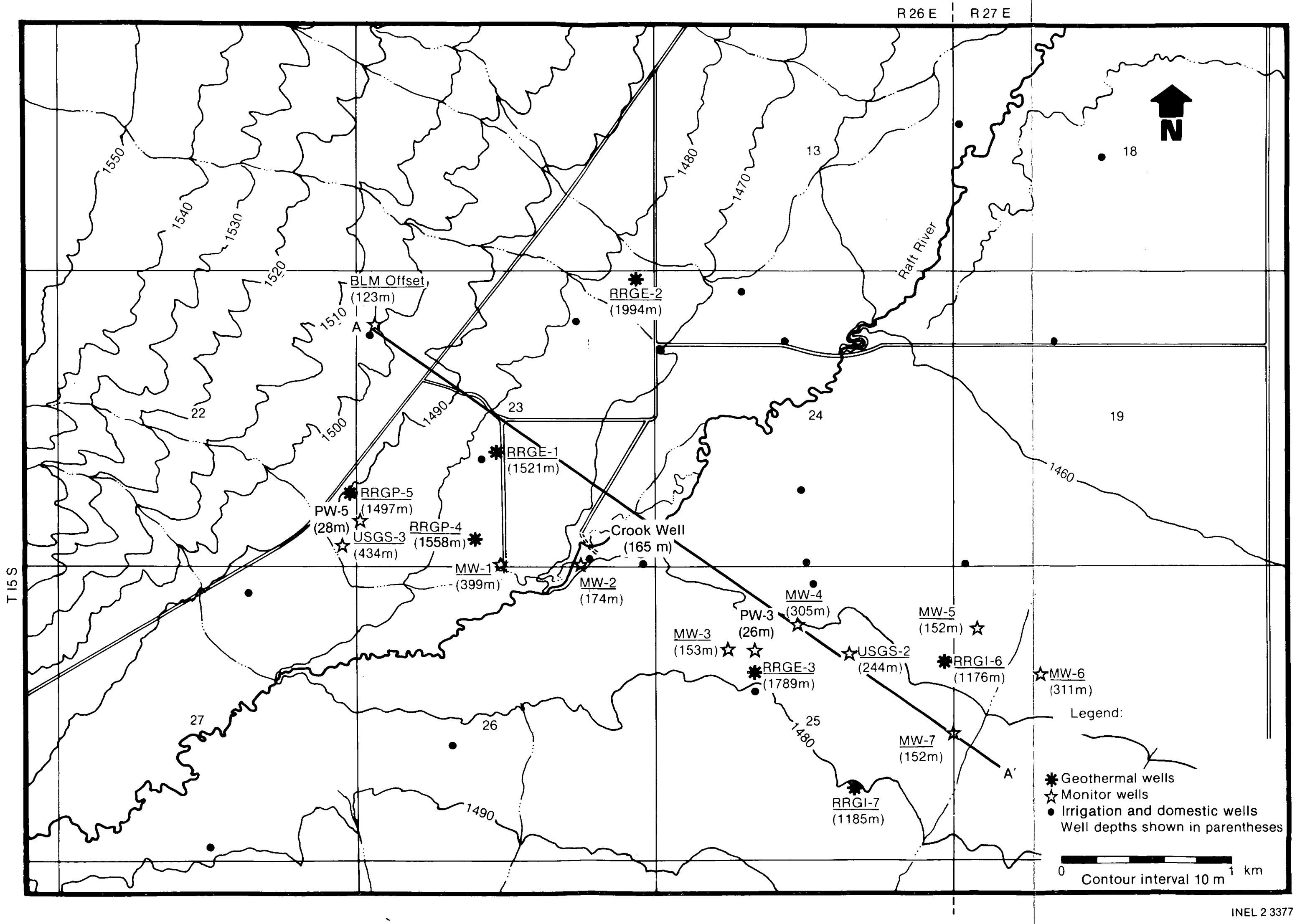

Figure 1. Location and depth of Raft River geothermal and monitor wells in addition to the location of Cross 


\section{PRODUCTION-INJECTION TESTING}

The injection system was originally designed to dispose of spent geothermal fluid from power generation by directly pumping it via a pressurized pipeline into the injection wells. The rationale for this closed system design was to:

1. Minimize cooling of the geothermal fluid prior to injection

2. Reduce the possibility of chemical precipitation

3. Prevent consumptive water loss via evaporation.

Several operational difficulties were associated with the closed system. The major source of problems was the need to precisely integrate the flow between production and injection wells. A malfunction within the network often necessitated a shutdown of the entire operation. These time consuming shutdowns were compounded by the occasional failures of the submersible production pumps. The operational life of these pumps was often limited to days or sometimes only minutes.

In 1981, the closed injection system was modified so that the disposed fluid flowed directly into an open pond. This allowed independent operation of the production and injection systems. The cooled water $\left(30^{\circ} \mathrm{C}\right)$ did not cause a decrease in fluid injectivity. Suspended particulates have not increased to a level detectably decreasing injectivity. Also, the submersible geothermal pumps were replaced by line-shaft geothermal pumps. These pumps have performed satisfactorily since their installation in July 1981. Table 2 summarizes the water volume and duration of the major $(80 \mathrm{~h}$ or greater) production and injection tests. For greater detail on production and injection testing see Reference 3.

Table 2. Major production and injection test from 1978 through 1982 (>80 h)

\begin{tabular}{|c|c|c|c|c|c|c|}
\hline Date & $\begin{array}{c}\text { Well } \\
\text { Number } \\
\end{array}$ & $\begin{array}{c}\text { Injection } \\
\text { Duration } \\
\text { (h) } \\
\end{array}$ & $\begin{array}{r}\text { Rate } \\
(\mathrm{L} / \mathrm{s})\end{array}$ & $\begin{array}{c}\text { Well } \\
\text { Number } \\
\end{array}$ & $\begin{array}{c}\text { Production } \\
\text { Duration } \\
\text { (h) } \\
\end{array}$ & $\begin{array}{r}\text { Rate } \\
(\mathrm{L} / \mathrm{s})\end{array}$ \\
\hline \multicolumn{7}{|l|}{1978} \\
\hline $05 / 30$ to $06 / 09^{a}$ & RRGI-4 & 221 & 45 & RRGE-2 & 221 & 45 \\
\hline \multicolumn{7}{|l|}{1979} \\
\hline $03 / 20$ to $04 / 10^{\mathrm{a}}$ & RRGI-6 & 504 & 39 & RRGE-2 & 504 & 39 \\
\hline $05 / 16$ to $06 / 06^{\mathrm{a}}$ & RRGI-6 & 483 & 40 & RRGP-5 & 483 & 40 \\
\hline $08 / 11$ to $08 / 15^{a}$ & RRGI-7 & 96 & 39 & RRGE-2 & 96 & 39 \\
\hline $10 / 15$ to $10 / 18^{a}$ & RRGI-7 & 80 & 63 & RRGE-1 & 80. & 63 \\
\hline \multicolumn{7}{|l|}{1980} \\
\hline $05 / 1.4$ to $06 / 12^{\mathrm{a}}$ & RRGI-6 & 700 & 44 & RRGE-3 & 700 & 44 \\
\hline $06 / 12$ to $06 / 17^{a}$ & RRGI-7 & 122 & 44 & RRGE-3 & 122 & 44 \\
\hline
\end{tabular}


Table 2. (continued)

\begin{tabular}{|c|c|c|c|c|c|c|}
\hline Date & $\begin{array}{c}\text { Well } \\
\text { Number }\end{array}$ & $\begin{array}{l}\text { Injection } \\
\text { Duration } \\
\text { (h) } \\
\end{array}$ & $\begin{array}{r}\text { Rate } \\
(\mathrm{L} / \mathrm{s}) \\
\end{array}$ & $\begin{array}{c}\text { Well } \\
\text { Number } \\
\end{array}$ & $\begin{array}{c}\text { Production } \\
\text { Duration } \\
\text { (h) }\end{array}$ & $\begin{array}{r}\text { Rate } \\
(\mathrm{L} / \mathrm{s}) \\
\end{array}$ \\
\hline \multicolumn{7}{|l|}{1980} \\
\hline $08 / 20$ to $08 / 28^{a}$ & RRGI-6 & 190 & 57 & RRGE-1 & 190 & 57 \\
\hline $08 / 28$ to $09 / 10^{a}$ & RRGI-7 & 285 & 57 & RRGE-1 & 285 & 57 \\
\hline \multicolumn{7}{|l|}{1981} \\
\hline $03 / 12$ to $03 / 16^{\mathrm{a}}$ & RRGI-7 & 92 & 42 & RRGP-5 & 92 & 42 \\
\hline $03 / 19$ to $03 / 30^{a}$ & RRGI-7 & 250 & 43 & RRGE-3 & 250 & 43 \\
\hline $10 / 19$ to $10 / 23^{b}$ & RRGI-7 & 63 & 72 to 75 & RRGE-1 & 66 & 66 to 68 \\
\hline $10 / 21$ to $10 / 23^{b}$ & RRGI-6 & 40 & 61 to 63 & RRGE-2 & 58 & 49 to 51 \\
\hline $10 / 27$ to $11 / 03^{b}$ & RRGI-7 & 73 & 60 to 62 & RRGE-1 & 120 & 63 to 65 \\
\hline \multirow[t]{2}{*}{$10 / 28$ to $11 / 03^{b}$} & RRGI-6 & 102 & 61 to 63 & RRGE-2 & 65 & 48 to 50 \\
\hline & & & & RRGE-3 & 65 & 35 to 37 \\
\hline \multicolumn{7}{|l|}{1982} \\
\hline $02 / 03$ to $02 / 08^{\mathrm{C}}$ & $-^{\mathrm{d}}$ & - & - & RRGE-1 & 118 & 17 to 19 \\
\hline $03 / 25$ to $06 / 15^{b}$ & RRGI-7 & 1416 & 60 to 63 & RRGE-1 & 1434 & 56 to 58 \\
\hline \multirow[t]{2}{*}{$03 / 25$ to $06 / 15^{b}$} & RRGI-6 & 1331 & 48 to5 1 & RRGE-2 & 1203 & 38 to 41 \\
\hline & & & & RRGE-3 & 1107 & 35 to 37 \\
\hline \multicolumn{7}{|c|}{ a. Direct hot water injection. } \\
\hline \multicolumn{7}{|c|}{$\begin{array}{l}\text { b. As of } 10 / 19 / 81 \text {, fluid disposal changed from direct hot injection, to disposal in open cooling } \\
\text { ponds at RRGI- } 6 \text { and }-7 \text { prior to injection. The time criteria of } 80 \mathrm{~h} \text { is total accumulated pumpage or } \\
\text { injection. }\end{array}$} \\
\hline \multicolumn{7}{|c|}{ c. Artesian flow test. } \\
\hline
\end{tabular}




\section{GEOLOGY AND GEOPHYSICS}

The geology and geophysics of the Raft River KGRA have been discussed in detail in numerous reports. ${ }^{3-8}$ These data, supplemented by regional geologic studies, $9-14$ provide a generalized concept of the geologic structure of the area.

The Raft River Basin is located in the hinterland of the Cordilleran fold and thrust belt of Idaho and Wyoming, and on the northern edge of the Basin-and-Range physiographic province. The hinterland is characterized by high-angle normal faulting, low-angle faulting emplacing younger over older rocks, moderate plutonism, and the presence of discontinuous metamorphic terranes. Low-angle faults active in the Mesozoic and Cenozoic, may have had additional movements related to changing tectonic settings. Movement on faults resulted from both large-scale regional crustal deformations and gravity glide off rising fault blocks or domes. 10

The mountain ranges surrounding the Raft River Basin display widely differing stratigraphy and structure. The Black Pine Mountains to the east (Figure 2) consist of late Paleozoic marine sediments and minor Tertiary volcanic sediments. Structurally the range exhibits high-angle normal faulting and low-angle thrusts emplacing younger over older sediments. The western flank of the range is downwarped into the Raft River Basin.

The Jim Sage Mountains to the west (Figure 2) are a late Tertiary anticlinal block with listric normal faults bounding the eastern margin. These faults are known as the Horse Well and Bridge Faults (Figure 2) and are thought to play a significant role in the geothermal system. This range is composed of the Tertiary Salt Lake Formation which also constitutes the major portion of the basin fill.

The Raft River Range to the south (Figure 2) exposes Precambrian, Paleozoic, and Triassic sedimentary rocks that were folded several times and displaced over great distances on low-angle faults. Transport was westward and northward during two episodes of metamorphism and eastward after the metamorphism. ${ }^{14}$ The range is an east-west oriented anticline uplifted in the Pliocene. It exposes two major allochthonous sheets overlying an autochthon consisting mainly of Precambrian rocks. The autochthon of the Raft
River Range forms part of the metamorphic sequence and basement rock found in the Raft River Valley at the KGRA. The units found in the basin consist of the Precambrian metamorphosed adamellite and the Precambrian (?) Older Schist, Elba Quartzite, Schist of the Upper Narrows, and the Quartzite of Yost. Both the Older Schist and the Quartzite of Yost are missing from Wells RRGE-1 and -2 . This could be a result of erosion or of low-angle faulting. Comption ${ }^{13}$ placed the low-angle fault at the base of the lowest allochthon at the contact between the Schist of the Upper Narrows and the overlying unit, the Schist of Stevens Springs. In an adjacent mapped area ${ }^{15}$ the low-angle fault at the base of the lowest allochthon was placed at the top of the Schist of Stevens Springs extending up through several overlying units. Although no low-angle faults have been mapped below this unit, there may be subsidiary faults or fracture planes present in the autochthonous units. Movement of the allochthons has been attributed to gravity glide on a broadly heated dome.

Figures 2, 3, and 4 depict the geologic model as it is conceptualized at present. The geologic cross section in Figure 4 has been superseded by that of Figure 3. However, with production zones $300 \mathrm{~m}$ below the top of the adamellite in RRGE-2, there is some evidence suggesting that the actual geologic model may be a combination of the cross sections in Figures 3 and 4. Because of the complex nature of the regional geologic setting, the structure in the Raft River Basin is poorly understood. The Horse Well and Bridge Faults are listric normal faults flattening to parallel the metasediments at depth. It is not certain whether these faults lie directly on top of the metasediments or whether they extend into the metamorphic and adamellite units. The Narrows structure has been poorly defined by anomalous data collected from geophysical surveys. It is thought to be a basement shear. Previously, this structure was assumed to have played a major role in the geothermal reservoir. ${ }^{7}$

The stratigraphy in the basin consists of the Quarternary Raft Formation (sand, silt, tuff, and minor rhyolite gravel), the Tertiary Salt Lake Formation (tuffaceous shale, siltstone, sandstone, and conglomerate), and the sequence of metamorphosed sediments and adamellite as named in the 


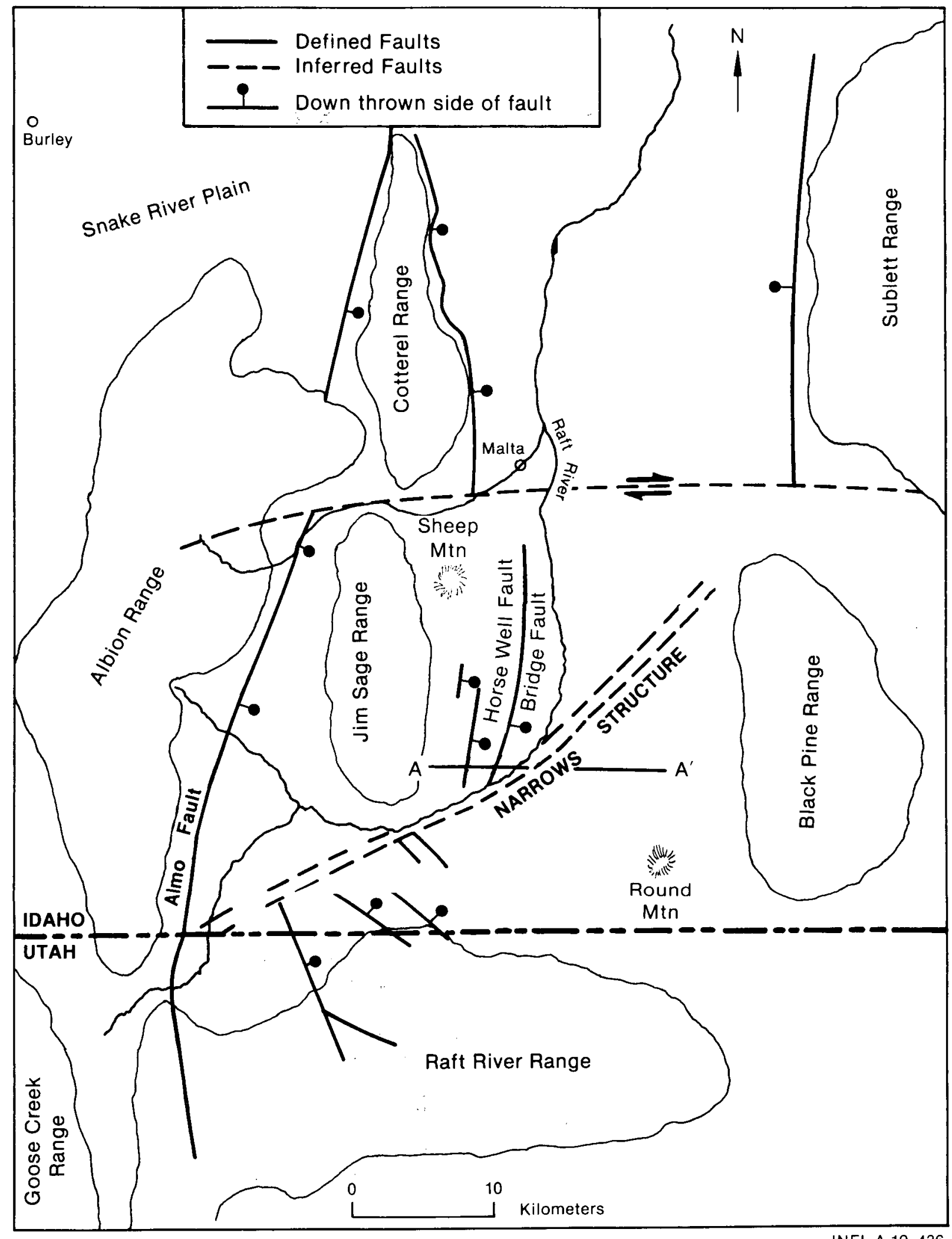

INEL-A.19 436

Figure 2. Raft River Valley and major structural features adjoining the valley. 


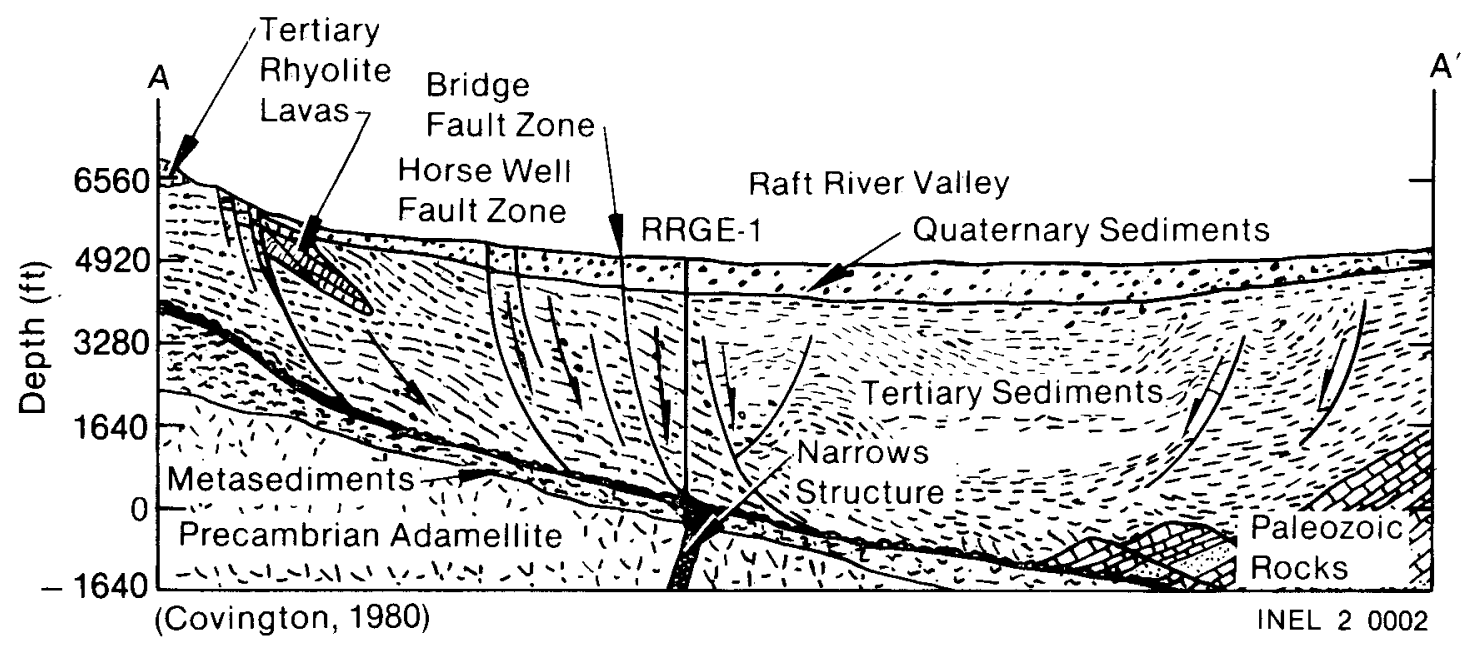

Figure 3. A recent interpretation of the geologic structure.

discussion on the Raft River Range. A basin-wide correlation of units within the sedimentary formations is difficult due to the nature of deposition. Hydrothermal alteration has resulted in the replacement of calcite by silica, fracture filling by secondary calcite and quartz, clay mineral alteration, and emplacement of secondary minerals, i.e., micas and sulfides.

\section{Aquifer/Aquitard Systems}

For purposes of understanding the subsurface strata and their complexities, as they relate to the local hydrology, the geologic units have been reorganized into six hydrologic aquifer/aquitard units. Figure 5 is a conceptual model of the flow system along Cross Section AA' in Figure 1. The conceptual model is based on minimal data and should be used with discretion. These systems include:

1. The Shallow Aquifer

2. The Upper Aquitard

3. The Lower Aquitard

4. The Intermediate Aquifer

5. The Geothermal Aquitard/Aquifer

6. The Metamorphic and Basement Aquifer.
The Shallow Aquifer is defined as the permeable unit present to a depth of $\sim 180 \mathrm{~m}$. The Upper Aquitard extends from $180 \mathrm{~m}$ to $\sim 335 \mathrm{~m}$. The Lower Aquitard (a tuff) extends from about $335 \mathrm{~m}$ to $\sim 450 \mathrm{~m}$, where the Intermediate Aquifer is encountered. This sand and gravel aquifer is highly transmissive and extends to a depth of $\sim 580 \mathrm{~m}$. The Geothermal Aquitard/ Aquifer is bounded by the rocks from about $580 \mathrm{~m}$ through the remainder of the Tertiary Salt Lake Formation. The unit behaves as an aquitard in preventing the upward movement of geothermal fluid, but is highly transmissive where the listric faults intersect each other and flatten to parallel or perhaps penetrate the metasediments and adamellite. The Geothermal Aquitard/ Aquifer contains several unfractured aquifers which are the injection zones in RRGI-7, (and to a lesser degree in RRGI-6) but also contains several fracture-controlled aquifers providing the majority of the geothermal fluid to the production wells. The local source of the geothermal fluid produced at Raft River is the Metamorphic and Basement Geothermal Aquifer, herein defined as the metasedimentary section and the adamellite basement. Major gravity-glide faulting occurs within this section. The faults serve as the principal source of geothermal heat and as the major hydraulic conduits for fluid movement from the recharge area (presumably in the Jim Sage Mountains) to the discharge area (Raft River flood plain). A more detailed discussion of each of the systems follows. 


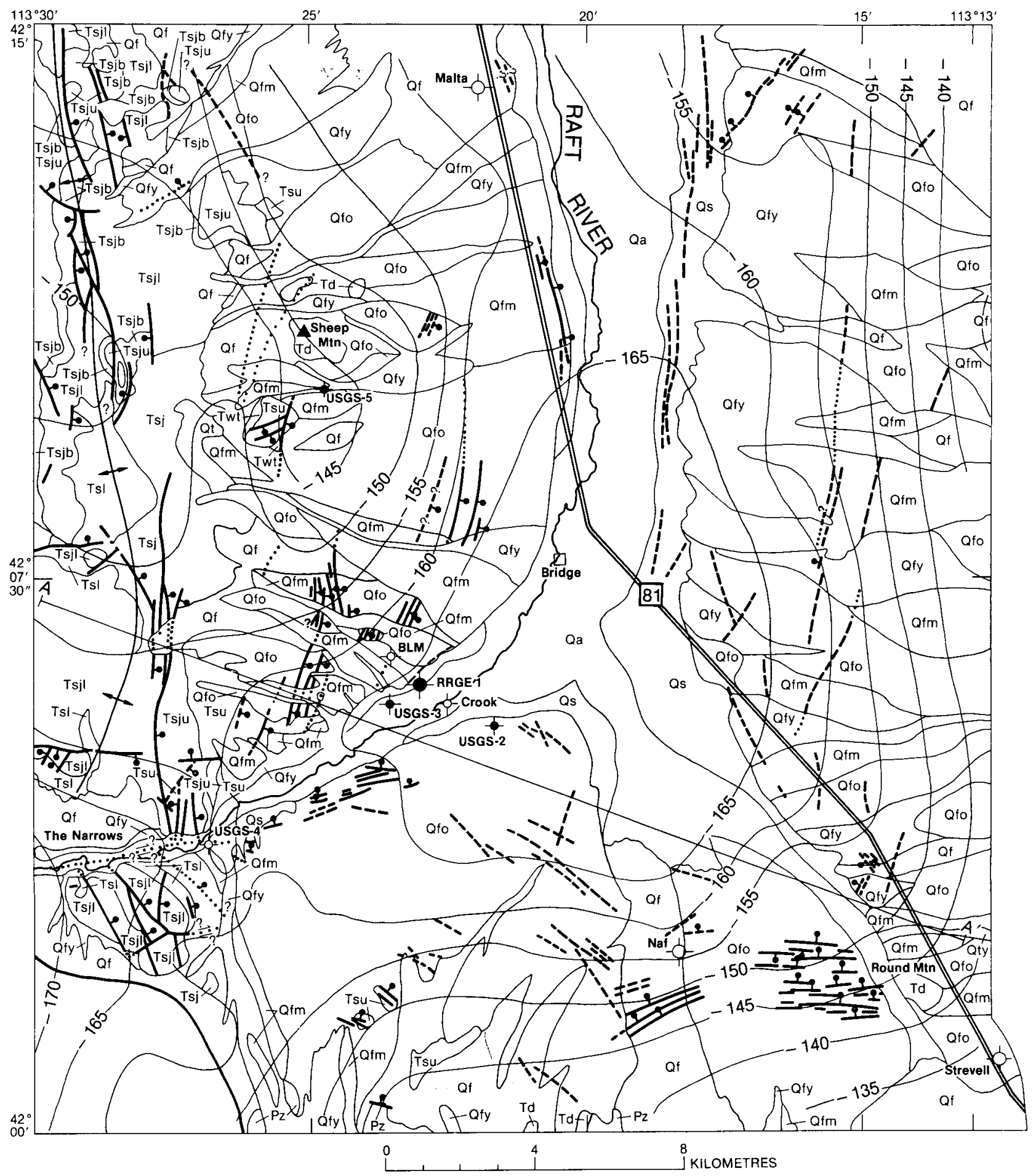

Figure 4. Geologic and gravity map of the southern Raft River Valley. 


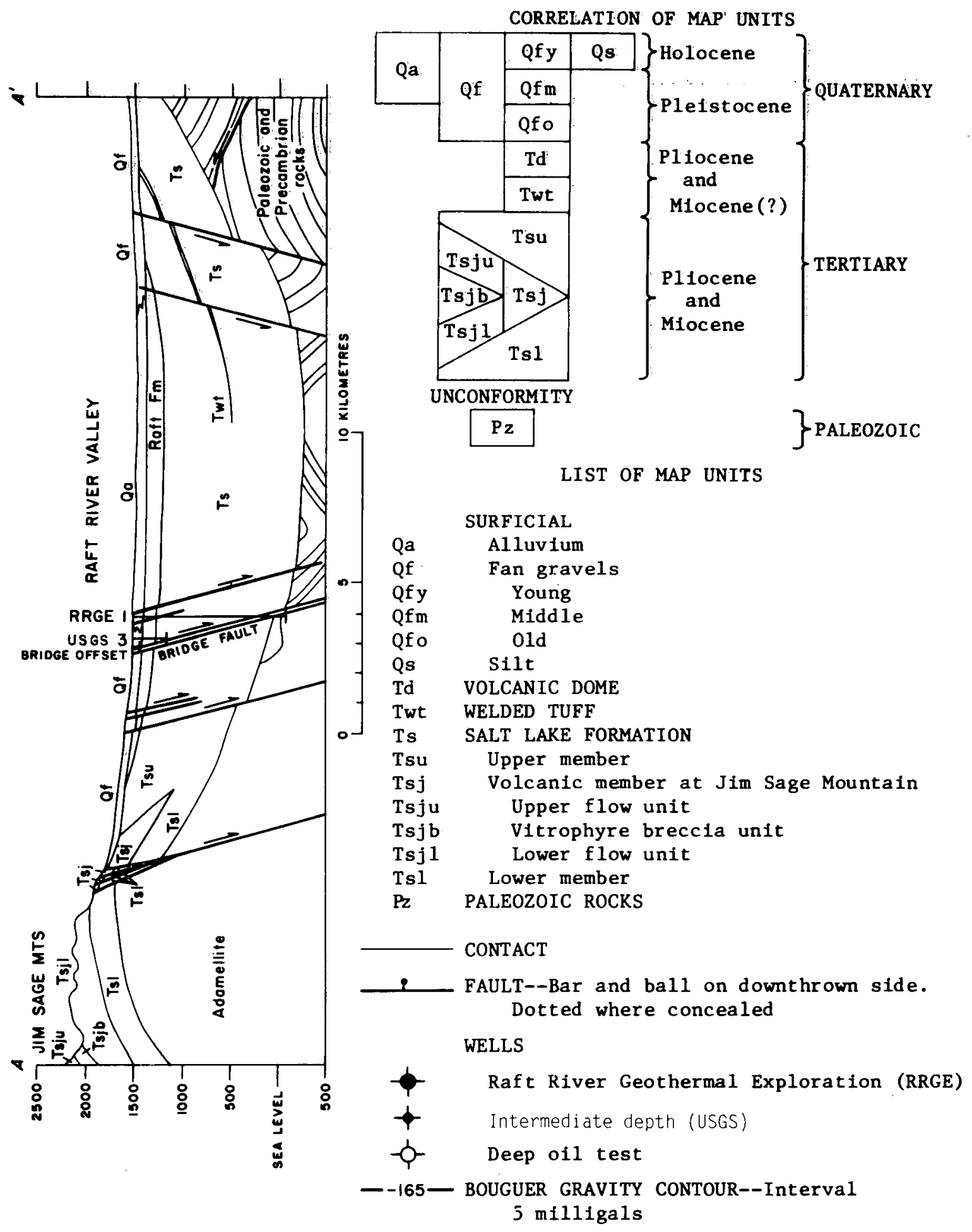

Geology based on References 4 and 12 .

Figure 4. (continued). 


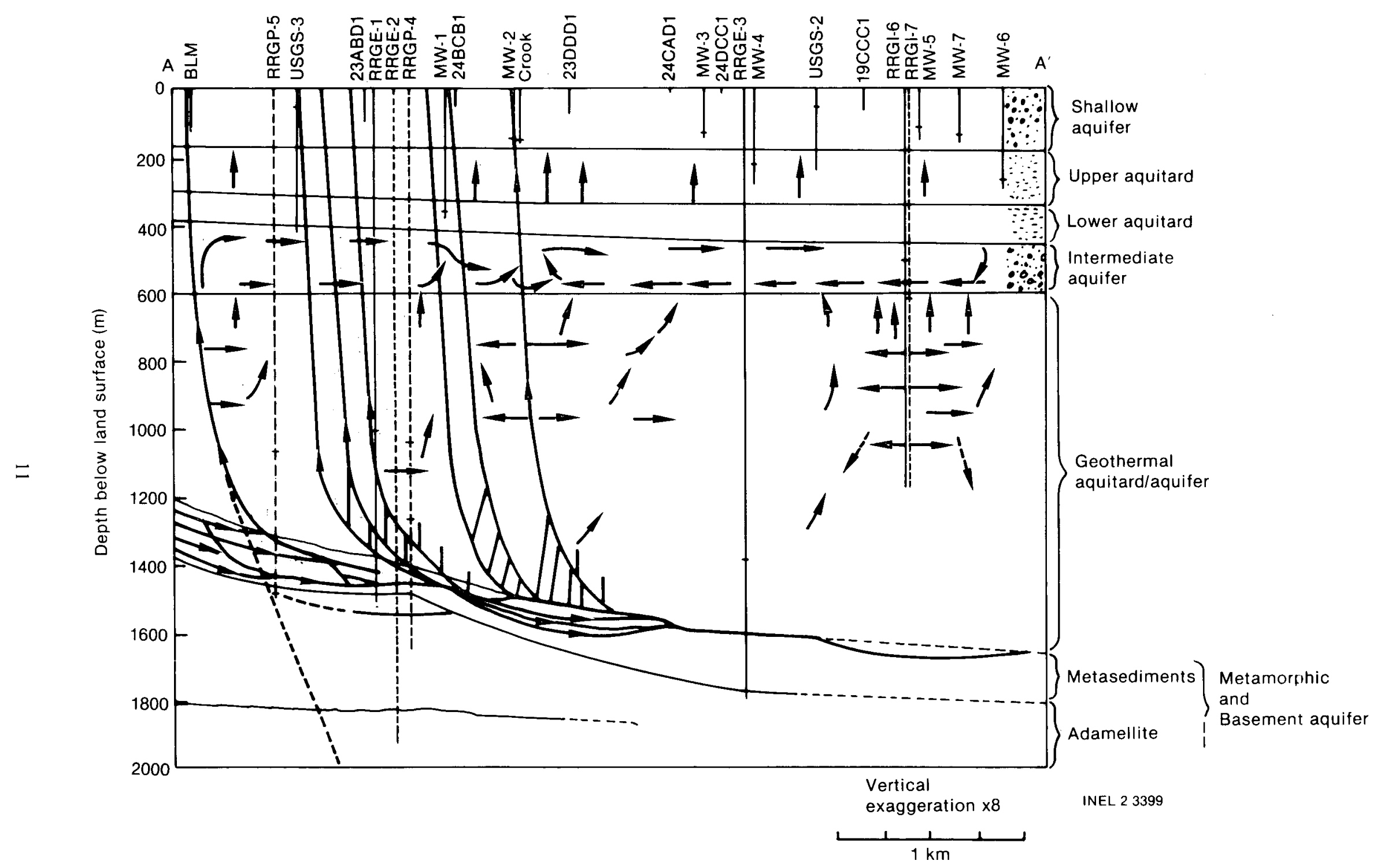

Figure 5. Cross Section $\mathbf{A A}^{\prime}$ of conceptual ground-water flow system. 


\section{HYDROGEOLOGY}

\section{Shallow Aquifer Hydrology}

The ground-water flow system, as perceived at the Raft River Known Geothermal Resource Area (KGRA), is complex and not completely understood. The uppermost unit consists of the Shallow Aquifer and extends to a somewhat arbitrarily defined depth of $180 \mathrm{~m}$, below which the permeability decreases. The deepest local irrigation well is $\sim 140 \mathrm{~m}$ deep with most wells being $\sim 80 \mathrm{~m}$ deep. Domestic water wells are normally completed as shallow as possible. The Shallow Aquifer is recharged by local precipitation, infiltration of surface waters, and upward porous media seepage and soft sediment fault/fracture flow from the underlying geothermal system. In the KGRA, the greatest geothermal discharge to the shallow flow system appears to be centered near the Crook well, Monitor Well (MW)-2 and -3. The dominant lateral flow component is directed towards the northeast, parallel to the Raft River. The Shallow Aquifer flow system has been significantly impacted locally by natural recharge from the underlying geothermal flow system.

\section{Monitor Well Potentiometric Head Response}

\section{Pit Well-3 (PW-3)}

- Wellhead elevation-1470 m

- Well depth-26 m

- Open borehole-1453 to $1444 \mathrm{~m}$.

This well is one of the six wells whose potentiometric heads are representative of those occurring in the Shallow Aquifer located to the north of RRGE-3 (Figure 1) in the expected flow path of spent geothermal fluid disposed in a pond that is no longer in use. The annual fluctuations in the potentiometric head in this well are the largest of all the monitor wells (Figure 6). For example, in 1981 , the potentiometric head declined $6.6 \mathrm{~m}$ followed by a rise of $6.3 \mathrm{~m}$. Over the period of record, only a slight net annual decline in potentiometric head has resulted in this well. The potentiometric head recovers during the nonirrigation season due to the decay of the "cone" of depres- sion caused by irrigation pumpage, due to natural and induced recharge and possibly due to the delayed drainage of irrigation water from the vadose zone. In 1982, there is no clearly defined response to injection or geothermal pumping (Figure 7) in the potentiometric head data that are obtained $\sim 3$ times weekly. The potentiometric head fluctuations in PW-3 are typical of those occurring in the Shallow Aquifer near the Raft River flood plain.

\section{Monitor Well-5 (MW-5)}

- Wellhead elevation-1475 m

- Well depth-152 m

- Slotted casing-1351 to $1334 \mathrm{~m}$

- Open borehole-1339 to $1323 \mathrm{~m}$.

This well is located on the Raft River flood plain (Figure 1) adjacent to an irrigated alfalfa field. The closest irrigation well is $-0.4 \mathrm{~km}$ to the north. This well is strongly affected by irrigation pumping (Figure 8) which results in potentiometric head declines ranging from $6.1 \mathrm{~m}$ in 1979 to $4.6 \mathrm{~m}$ in 1980 . Potentiometric heads recovered from $4.7 \mathrm{~m}$ in 1979 to $4.3 \mathrm{~m}$ in 1980 , which resulted in net annual potentiometric head declines ranging from 1.4 to $0.3 \mathrm{~m}$ in 1979 and 1980 , respectively. The potentiometric head recovers during the nonirrigation season due to the decay of the "cone" of depression caused by irrigation pumpage, due to both natural and induced recharge, and possibly due to the drainage of irrigation water from the vadose zone. Induced recharge would be obtained, in part, from the underlying geothermal system as a result of the increased hydraulic gradient directed toward the Shallow Aquifer. The annual fluctuations in the potentiometric head, although less than PW-3, are typical of the Shallow Aquifer underlying the Raft River flood plain.

In 1982, (Figures 7 and 8) the trend in the potentiometric head follows the usual seasonal trend. The potentiometric head in this well declines in response to injection, presumably due to slight dilation of the Shallow Aquifer (Figure 7). The potentiometric head increases when injection stops. Small declines and increases 


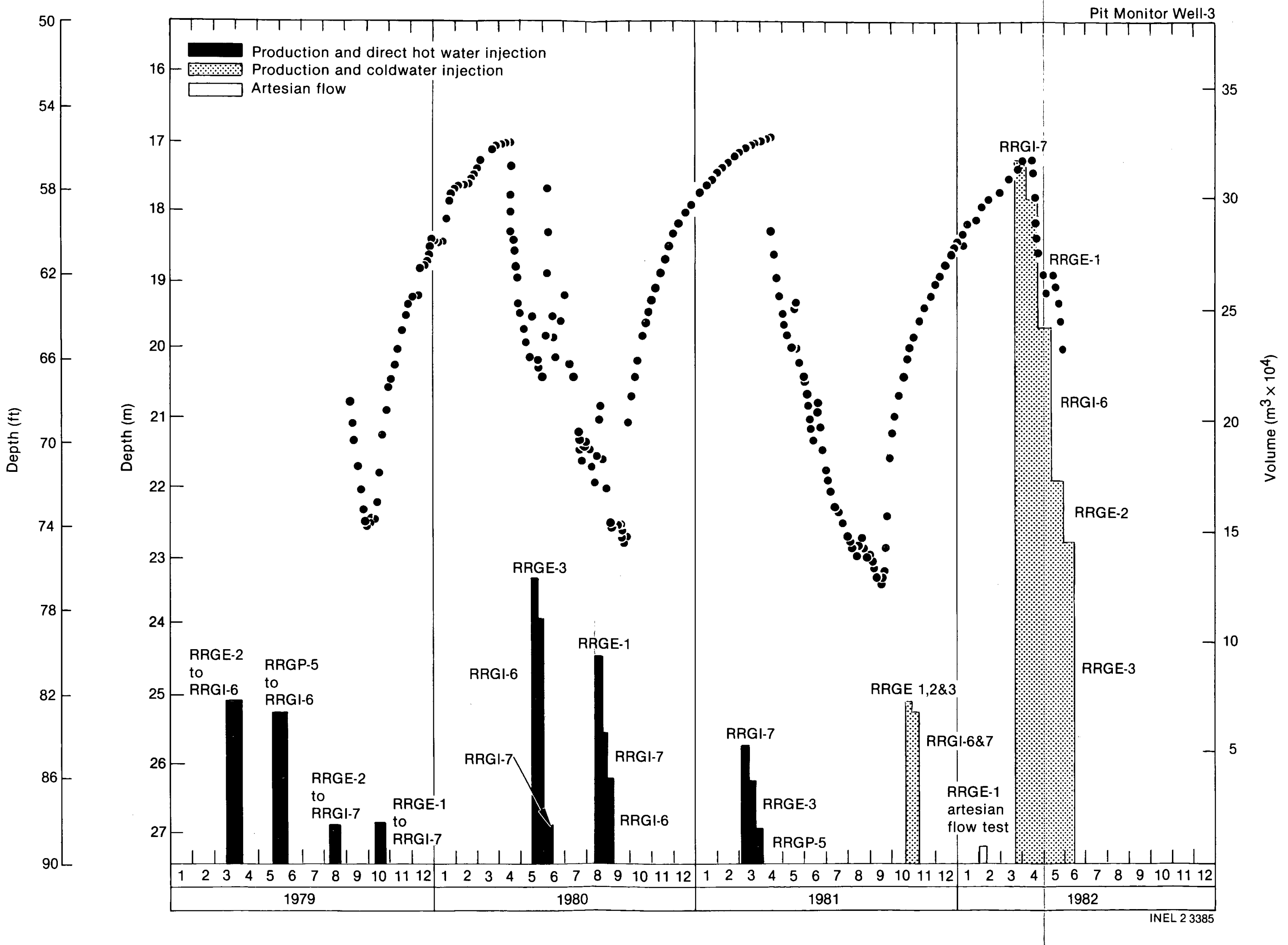

Figure 6. PW-3 long-term hydrograph. 

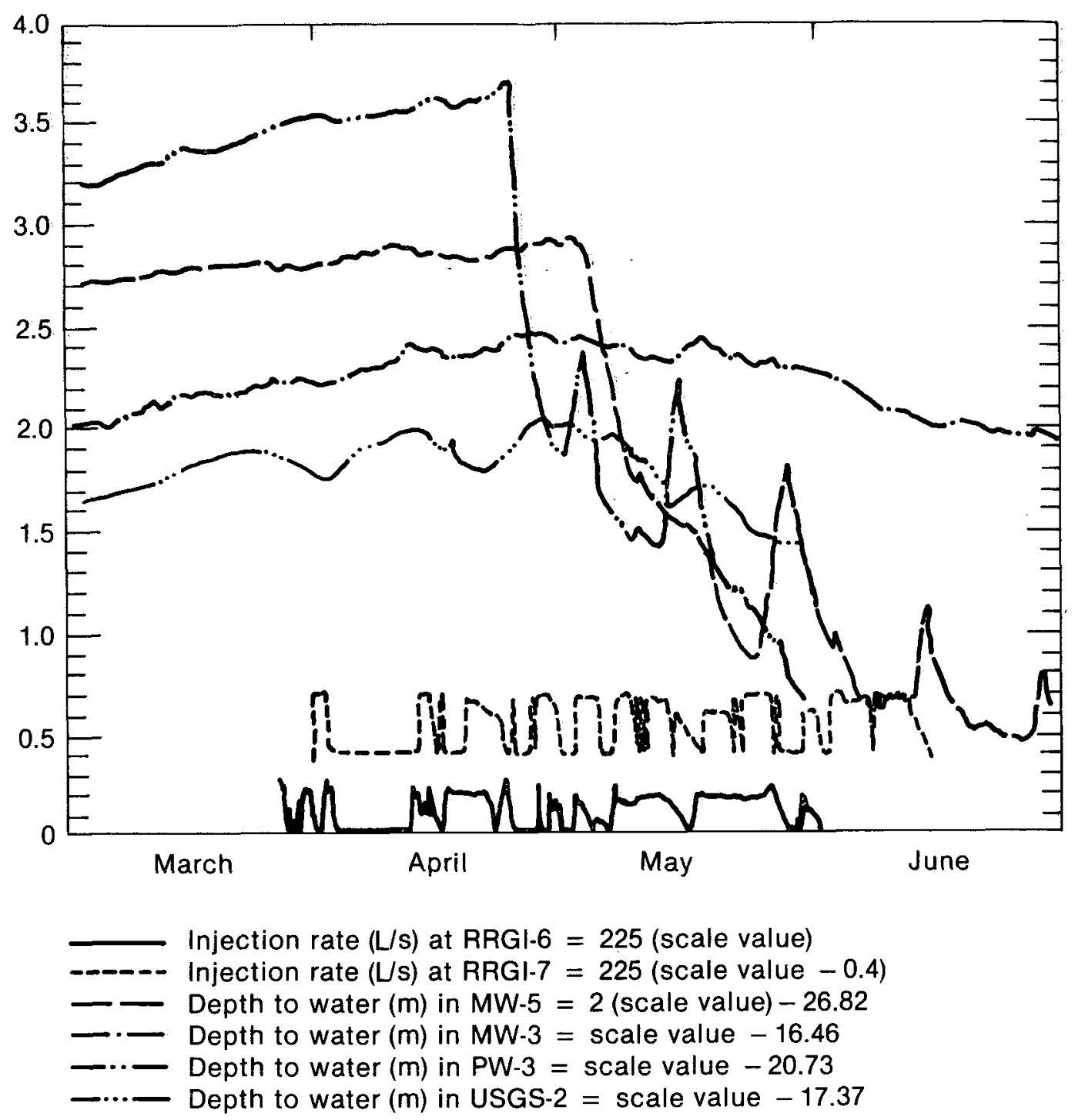

INEL 23445

Figure 7. Hydrographs for PW-3, MW-3, -5, USGS-2, and injection rates for RRGI-6 and -7 from March to June 1982.

in the potentiometric head of $\sim 0.12 \mathrm{~m}$ result from March 25 (when injection began) until May 2. Previous data also indicate that MW-5 responds negatively to injection into RRGI-6. After May 2, interference from irrigation pumping overwhelmed the effects due to injection. Thus, during power plant operations in 1982, the potentiometric head in MW-5 declined $\sim 0.12 \mathrm{~m}$ during periods of injection and it increased by $0.12 \mathrm{~m}$ following periods of injection.

\section{Monitor Well-3 (MW-3)}

- Wellhead elevation-1472 m
- Well depth-153 m

- Slotted casing-1332 to $1319 \mathrm{~m}$.

MW-3 is located on a sideslope above the Raft River flood plain (Figure 1). The potentiometric head fluctuations in this well are typical of those in the Shallow Aquifer where it is affected by irrigation (Figure 9). Potentiometric head declines, due to irrigation pumpage range from $2.01 \mathrm{~m}$ in 1980 to $2.93 \mathrm{~m}$ in 1981. During the period 1979 to 1982 , the average annual net decrease in the maximum yearly potentiometric heads was $0.22 \mathrm{~m}$. There is no obvious response in 


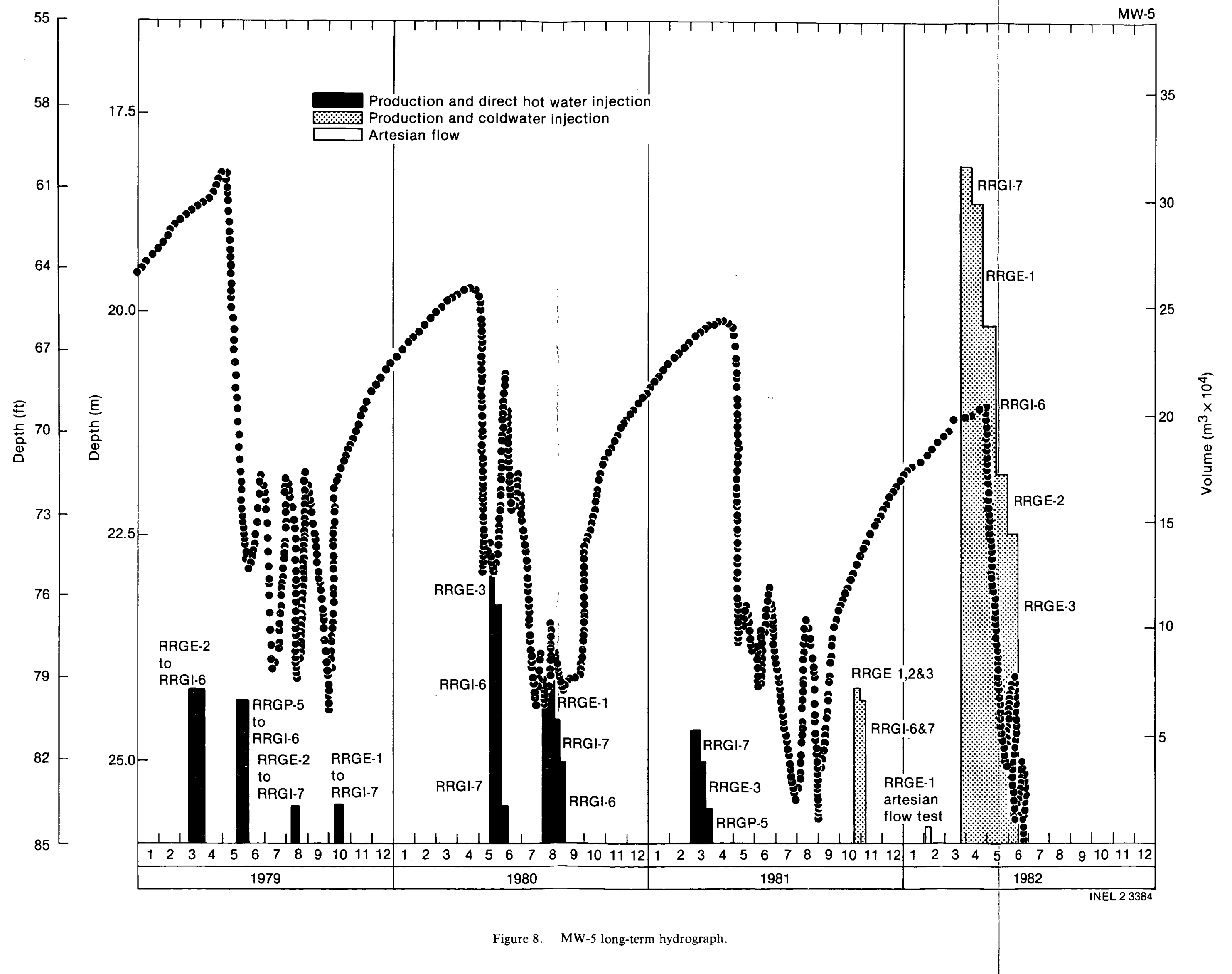




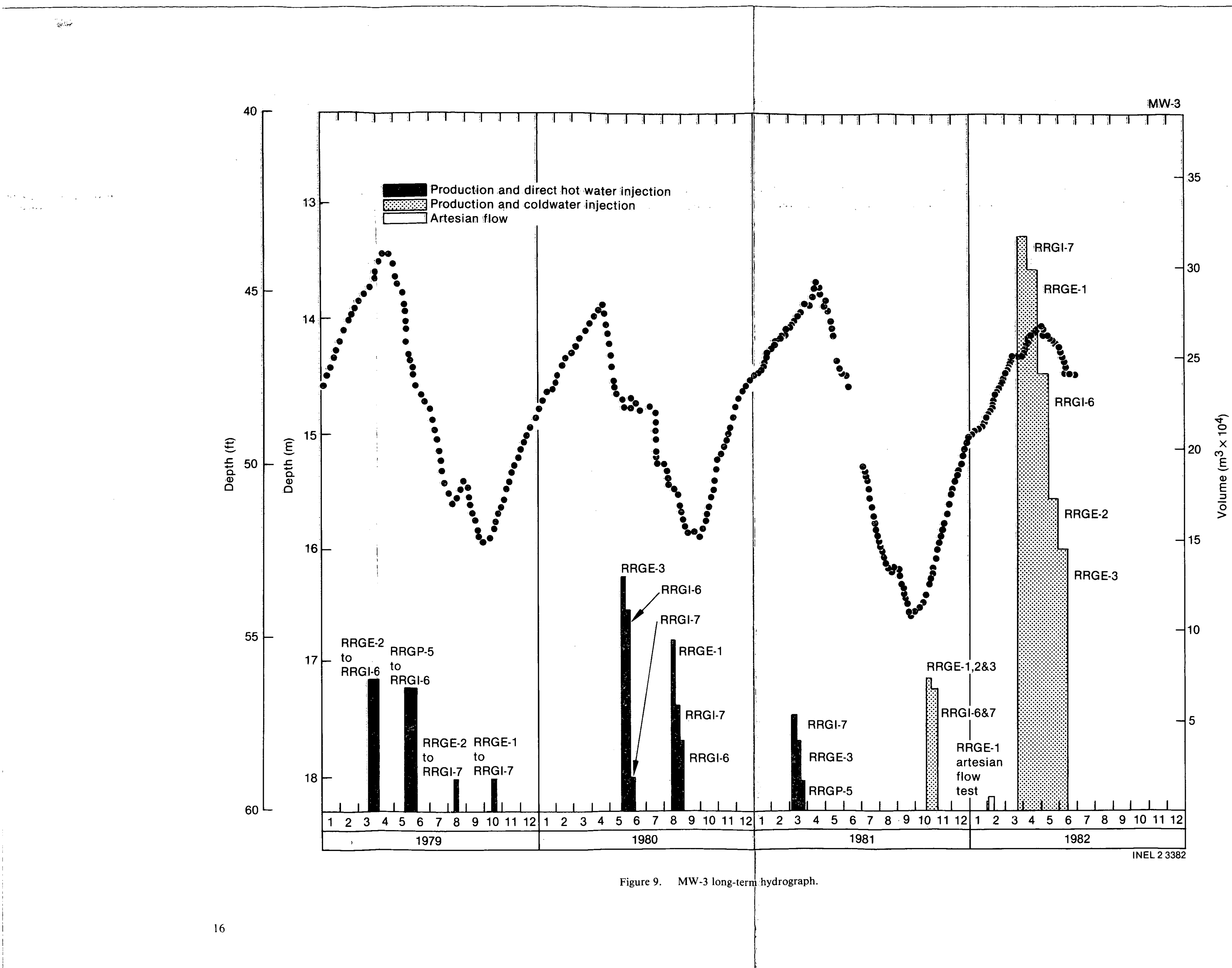


the potentiometric head due to injection or geothermal pumping. The overall annual hydrograph is typical of that in the Raft River flood plain Shallow Aquifer.

The potentiometric head in MW-3 follows a seasonal rising trend during the first 4 months of 1982 (Figure 9). The record for the previous 3 years indicates a similar head rise. The potentiometric head decline started on May 2 (Figures 7 and 9). This declining trend is not as well pronounced as in the previous years. During the month of May the head declined from a depth of 14.05 to $14.20 \mathrm{~m}$ and during the first 2 weeks of June from 14.20 to $14.45 \mathrm{~m}$. Some limited "negative" response to injection is possible, but is much less distinctive than in MW-5, -6 , and -7 .

\section{USGS-2}

- Wellhead elevation-1473 m

- Well depth-244 m

- Open borehole-1409 to $1229 \mathrm{~m}$.

This well has one of the longest periods of record, which is plotted beginning in 1976 (Figure 10). It is located on the valley sideslope above the Raft River flood plain (Figure 1). Although this well is $244 \mathrm{~m}$ deep, it only has $64 \mathrm{~m}$ of casing; this results in an uncased borehole extending from the Shallow Aquifer into the Upper Aquitard. Because of the higher transmissivity of the Shallow Aquifer, the potentiometric head in USGS-2 can be expected to closely resemble that in the Shallow Aquifer. This assumption is substantiated when, in 1980, the maximum annual potentiometric head decline was $2.90 \mathrm{~m}$ in USGS-2 and only $2.01 \mathrm{~m}$ in MW-3, a well $153 \mathrm{~m}$ deep. Thus, it appears that USGS- 2 is essentially a Shallow Aquifer monitor well. The decline in maximum annual potentiometric head averages $0.43 \mathrm{~m} / \mathrm{yr}$ from 1977 to 1981 , a total decline of $2.16 \mathrm{~m}$. The hydrograph for this well indicates a long-term decline in potentiometric heads in the Shallow Aquifer in the vicinity of the Raft River KGRA.

The potentiometric head fluctuation at USGS-2 follows the usual seasonal trend in 1982 (Figures 10 and 7). The poteritiometric head rise continues through the first 4 months of 1982 and ends on May 2. The slight decline at the end of
March and again on April 12 through 21 is similar to that at MW-5, -6 , and -7 . It probably represents a negative response to the injection. The seasonal potentiometric head decline, due to irrigation starts on May 2. A rise in the potentiometric head from June 15 until at least June 30 is presumed to be in response to injection which ended June 15. Thus, the USGS-2 potentiometric head declines, due to injection, followed by a rise, after injection ceases.

\section{Monitor Well-7 (MW-7)}

- Wellhead elevation-1474 m

- Well depth-152 m

- Slotted casing-1334 to $1322 \mathrm{~m}$.

MW-7 is located on the valley sideslope above the Raft River flood plain (Figure 7). The potentiometric head in this well exhibits a long-term decline (Figure 11). The annual declines due to pumpage range from $2.16 \mathrm{~m}$ in 1980 to $2.74 \mathrm{~m}$ in 1979. Net annual declines of yearly maximum potentiometric heads range from 0.29 to $0.91 \mathrm{~m}$. The smaller annual fluctuations at MW-7, as compared to PW-3 and MW-5, indicate that MW-7 is further removed hydrologically from the irrigation pumping. The potentiometric head in this well also exhibits a decline when injecting into RRGI-6, which is followed by a rise when injection ceases. Thus, the potentiometric head at MW-7 responds to irrigation pumping and injection by declining, as was observed in several other Shallow Aquifer monitor wells.

In 1982 , the potentiometric head response to injection is similar to the response in MW-5 and -6 (Figure 12). The "negative" response is clearly visible beginning March 25 when the injection started. The potentiometric head declines and rises are correlated with the beginning and ending of injection, respectively. The overall rising trend ended on March 25, when injection began, and began again on April 2 when the injection pumping ceased. From April 12 until May 2, potentiometric head fluctuations are dominated by responses to injection pumping. The single sudden decline in the potentiometric head caused by the beginning of injection is $-0.010 \mathrm{~m}$. The best illustration of the potentiometric head response to injection is observed between April 12 and 16. The series of potentiometric head declines and partial 


$$
\text { unduce }
$$




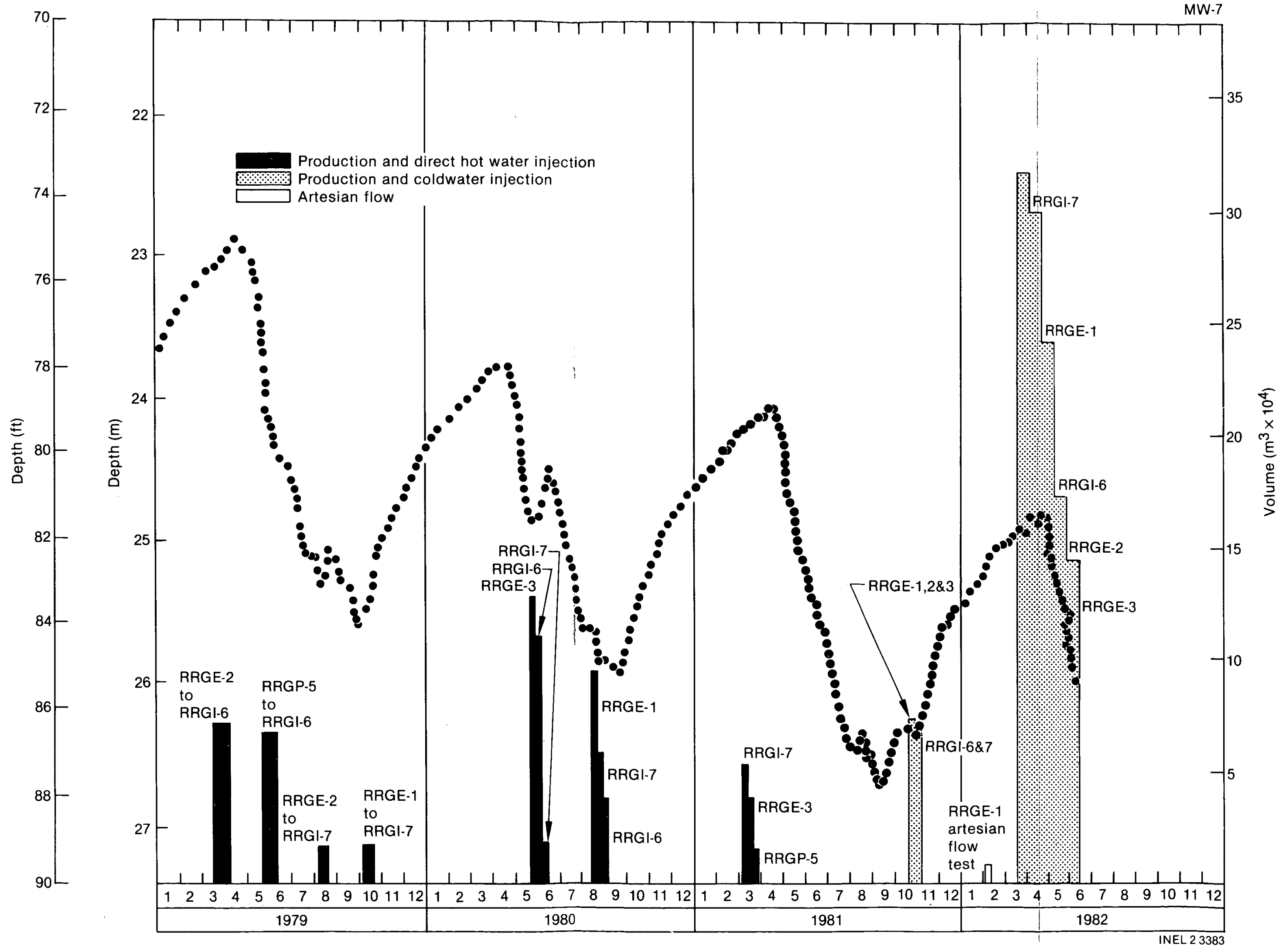

Figure 11. MW-7 long-term hydrograph. 


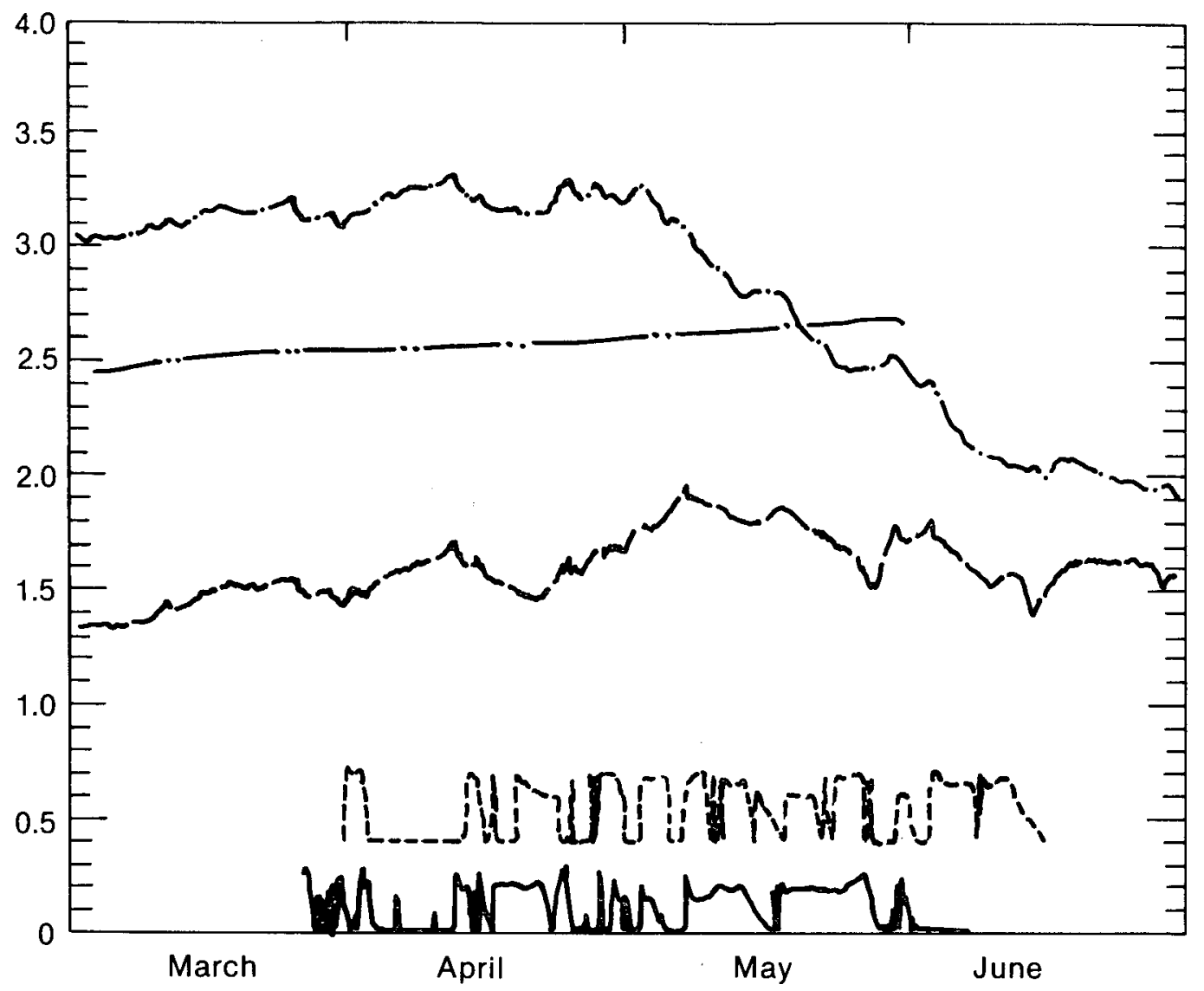

Injection rate $(\mathrm{L} / \mathrm{s})$ at RRGI-6 $=225$ (scale value)
-- Injection rate $(\mathrm{L} / \mathrm{s})$ at RRGI-7 $=225$ (scale value -0.4$)$
- Depth to water $(\mathrm{m})$ in MW-6 $=$ scale value -24.08
$-\cdots$ - Depth to water $(\mathrm{m})$ in $\mathrm{MW}-7=$ scale value -28.04
- Depth to water $(\mathrm{m})$ in $\mathrm{PW}-5=$ scale value -16.54

INEL 23446

Figure 12. Hydrographs for MW-7, -6, PW-5, and injection rates for RRGI-6 and -7 from March to June 1982.

recoveries closely follow the injection startups and shutdowns. Short interruptions between injections did not allow for full recovery. During the longer duration injection between April 16 and 22, the potentiometric head stabilized. At the end of April, the irregular potentiometric head fluctuations correspond to the irregular injection pattern. Beginning May 2, irrigation pumpage dominated the potentiometric head fluctuations at MW-7. However, at the end of injection on June 15, a slight recovery of about $0.010 \mathrm{~m}$ was observed. This recovery is probably one more illustration of the response to the injection pumping.

\section{Pit Well-5 (PW-5)}

- Wellhead elevation-1490 m

- Well depth-28 m

- Slotted casing-1478 to $1462 \mathrm{~m}$.

The smooth seasonal potentiometric head trend observed in this well (Figure 13) is atypical of any other monitor well in the network. The pattern suggests that the aquifer monitored by this well is not detectably affected by either irrigation or by 


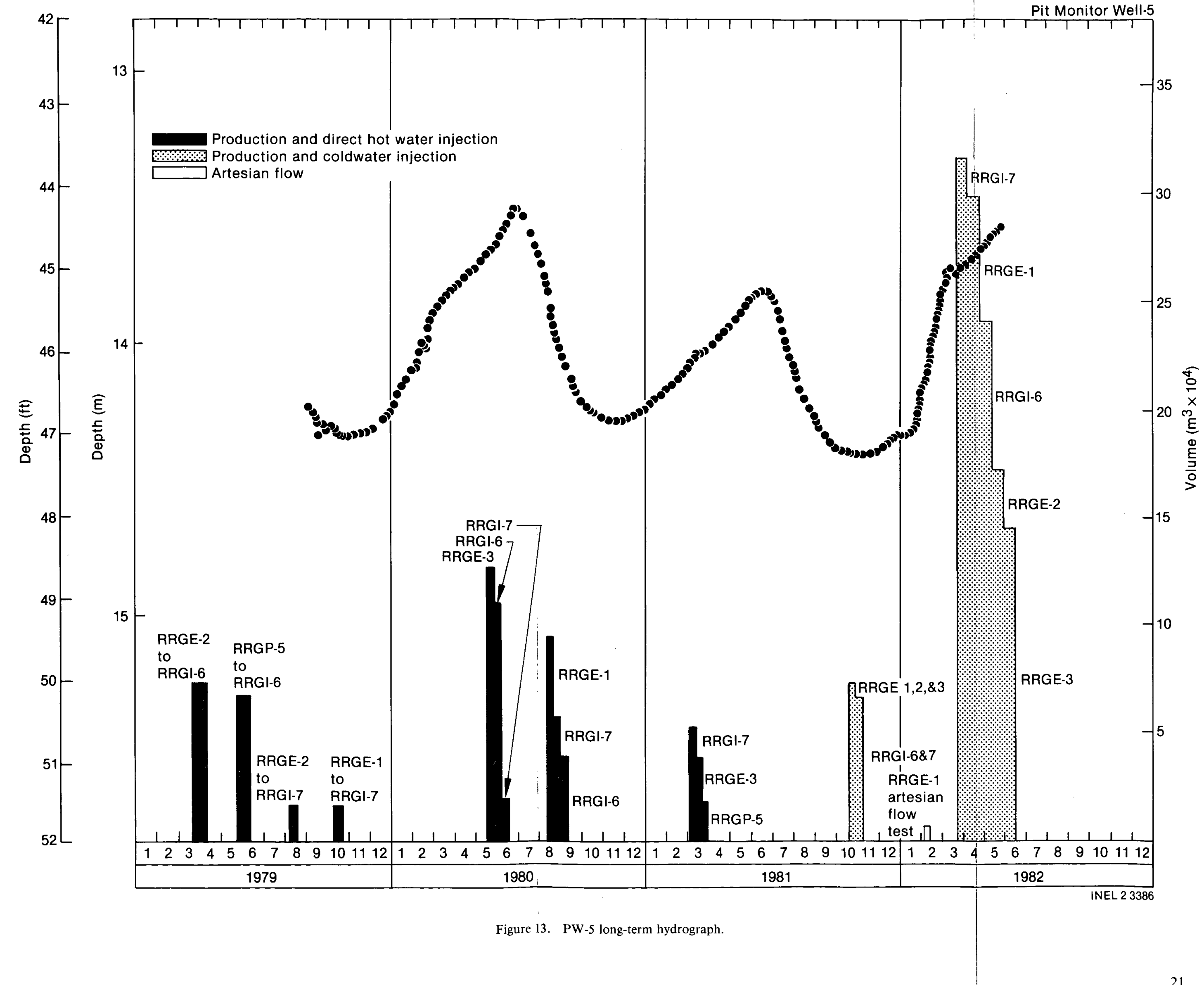


geothermal injection or pumping. Rather, the pattern reflects that expected in a natural, undisturbed ground-water system. A steady rise in the potentiometric head begins in mid-November and continues until mid-June. This rise coincides with the period of natural recharge for the region. As the recharge effects of snowmelt and precipitation cease, the potentiometric head begins to decline. This decline is sustained through the typically low precipitation months of summer and early autumn, and ends when autumn precipitation increases.

During 1982, (Figure 12), the potentiometric head in the PW-5 increased continuously during the period, January through May (end of the record). The steady rise is undisturbed by injection pumping or by irrigation withdrawals. The potentiometric head regime represents an undisturbed natural seasonal cycle.

\section{Geochemistry}

The quality of groundwater in the Shallow Aquifer, as measured by dissolved constituents and temperature, is affected by the geothermal system. Table $3^{3}$ lists selected physical and chemical data for Raft River wells. During the period from 1978 to 1981 , Figure 14, the water quality in the monitor wells is presumed to be temporally independent. The observed variations in specific conductance and other constituents may be a result of sampling and analytical errors. Figure 15 depicts the specific conductance of shallow wells less than approximately $150 \mathrm{~m}$ in depth. The poorest quality water in the Shallow Aquifer occurs in the vicinity of the Crook well, $\mathrm{MW}-2$, and -3 . Figure 16 depicts the temperature of water in the shallow wells. The temperature pattern is very similar to that for the specific conductance. Both the specific conductance and temperature data indicate a significant discharge of geothermal fluids into the Shallow Aquifer. However, within the Shallow Aquifer system, abrupt lateral and vertical variations in water quality exist, with the lowest specific conductance waters generally being the shallowest. For example, the specific conductance in the shallow Crook domestic well near MW-2 is $<1100 \mu \mathrm{S}$. The shallow domestic wells can be expected to be least affected by the geothermal leakage due to the proximity of the well's uncased borehole to the high quality local recharge originating from precipitation and surface water infiltration. Some degradation of the domestic wells' water quality may have resulted due to irrigation using deeper well water. In contrast to these fresh waters in the Shallow Aquifer, significant degradation in water quality.(specific conductance) results from natural geothermal discharge apparently centered near the Crook well, MW-2, and -3. MW-2, which is only $174 \mathrm{~m}$ deep, does not monitor water quality and changes in the potentiometric head that are strictly associated with those in the Shallow Aquifer. This well is actually monitoring the quality of the Intermediate Aquifer via an apparent soft sediment fault. The potentiometric head changes are basically those believed to be occurring in the Intermediate Aquifer, but are modified by leakage, (and thus potentiometric head changes) occurring within the Shallow Aquifer. Thus, although the depth of a monitor well may imply it is monitoring the water quality in a particular hydrologic unit, this is not always the case when faults, fractures, and hydrologic discontinuities permit a hydrologic connection with a more transmissive unit at a higher potentiometric head.

Cross sections of selected physical and chemical parameters have also been constructed. The Cross Section AA' in Figure 1 has been used to depict gross vertical distributions of specific conductance and temperature. The contours are somewhat speculative since the control points are sparse. Figure 17 is a cross section depicting the distribution of temperature. In the Shallow Aquifer system, the temperature reaches a maximum near MW-2 and -3, possibly near the intersection of NNE and NW trending faults (Figure 4). These faults are discussed in greater detail in the Metamorphic and Basement Aquifer section. The temperature distribution in monitor wells between MW-2 and -6 reflects the thermal gradients and temperatures in Figure 18. Figure 18 contains temperature logs obtained during 1978 . The ranking of the wells from lowest to highest temperatures (below a depth of $30.5 \mathrm{~m}$ ) is MW-6, -5, -7, $-4,-3$ and -2 . In general, the thermal gradients, which range from 0.011 to $0.030^{\circ} \mathrm{C} / \mathrm{m}$, have a similar ranking with the exception of MW-2. This well has a low thermal gradient because of its proximity to a fault where leakage into the Upper Shallow Aquifer undoubtedly occurs, thereby increasing the temperature of the Shallow Aquifer. There is also an apparent increase in temperature laterally from the BLM well towards MW-2. The temperature profile in Figure 17 is 


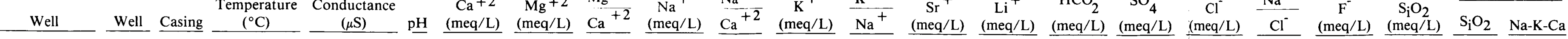

\begin{tabular}{|c|c|c|c|c|c|c|c|c|c|c|c|c|c|c|c|c|c|c|c|c|c|c|}
\hline RRGE-1 & 1521 & 1105 & 141 & 2000 & 7.7 & - & - & - & 16.348 & - & - & - & - & - & 0.934 & - & 17.569 & 0.931 & 0.466 & - & - & - \\
\hline RRGE-2 & 1994 & 1289 & 144 & 2160 & - & 1.597 & 0.038 & 0.024 & 14.609 & 9.148 & 0.819 & 0.056 & 0.018 & 0.144 & 1.000 & 1.157 & 16.694 & 0.875 & 0.526 & 158 & 164 & - \\
\hline RRGE-3 & 1789 & 1293 & 149 & 8000 & 6.9 & 11.180 & 0.041 & 0.004 & 51.915 & 4.644 & 2.686 & 0.052 & 0.119 & 0.447 & 0.721 & 1.249 & 63.732 & 0.815 & 0.258 & 158 & 164 & 187 \\
\hline RRGP-4 & 1558 & 1049 & 142 & 7400 & 7.4 & 7.337 & 0.016 & 0.002 & 66.307 & 9.037 & - & - & 0.146 & 0.447 & 0.688 & - & 72.756 & 0.911 & 0.237 & 104 & 136 & - \\
\hline RRGP-5B & 1497 & 1034 & 135 & 2400 & 7.5 & 2.046 & 0.008 & 0.004 & 21.044 & 10.285 & 0.793 & 0.038 & 0.027 & 0.231 & 0.574 & 0.833 & 22.560 & 0.933 & 0.379 & 133 & 154 & 169 \\
\hline RRGI-6 & 1176 & 509 & 107 & 10800 & 7.2 & 8.535 & 0.115 & 0.013 & 95.656 & 11.207 & 0.819 & 0.009 & 0.183 & 0.735 & 1.196 & 1.249 & 102.648 & 0.932 & 0.300 & 94 & 134 & 114 \\
\hline RRGI-7 & 1185 & 623 & 122 & 12000 & - & 17.469 & 0.123 & 0.007 & 95.656 & 5.476 & - & - & - & - & 0.524 & 1.332 & 112.800 & 0.848 & 0.258 & 83 & 127 & - \\
\hline \multicolumn{23}{|l|}{ Monitor } \\
\hline MW-1 & 399 & 369 & - & 11400 & 7.6 & 10.731 & 0.033 & 0.003 & 95.656 & 8:914 & 0.767 & 0.008 & 0.144 & 0.533 & 0.410 & 1.374 & 103.776 & 0.922 & 0.179 & 80 & 125 & 110 \\
\hline MW-2 & 174 & 154 & 106 & 5500 & 7.4 & 6.239 & 0.041 & 0.007 & 43.480 & 6.969 & 0.640 & 0.015 & 0.082 & 0.360 & 0.426 & 1.187 & 49.068 & 0.886 & 0.284 & 87 & 130 & 128 \\
\hline MW-3 & 153 & 140 & 71 & 6200 & 7.5 & 7.736 & 0.518 & 0.067 & 60.872 & 7.869 & 1.663 & 0.027 & 0.043 & 0.432 & 0.770 & 1.249 & 69.372 & 0.877 & 0.284 & 60 & 111 & 160 \\
\hline MW-4 & 305 & 225 & 97 & 7800 & 7.7 & 7.986 & 0.049 & 0.006 & 66.090 & 8.276 & 0.793 & 0.012 & 0.032 & 0.533 & 0.443 & 1.103 & 73.602 & 0.898 & 0.295 & 67 & 116 & 123 \\
\hline MW-5 & 152 & 124 & 28 & 2200 & 7.6 & 5.340 & 2.056 & 0.385 & 12.174 & 2.280 & 0.358 & 0.029 & 0.021 & 0.043 & 1.967 & 0.562 & 17.202 & 0.708 & 0.032 & 34 & - & - \\
\hline MW-6 & 311 & 274 & 44 & 7600 & 7.3 & 10.331 & 0.197 & 0.019 & 68.264 & 6.608 & 1.432 & 0.021 & 0.032 & 0.447 & 0.820 & 1.520 & 78.114 & 0.874 & 0.258 & 85 & - & - \\
\hline MW-7 & 152 & 140 & 35 & 2300 & 7.6 & 4.741 & 1.661 & 0.350 & 14.479 & 3.054 & 0.358 & 0.025 & 0.021 & 0.086 & 2.049 & 0.687 & 18.330 & 0.790 & 0.058 & 40 & - & - \\
\hline \multicolumn{23}{|c|}{ USGS Monitor } \\
\hline USGS-2 & 244 & 64 & 59 & 1960 & 7.7 & 2.545 & 0.329 & 0.129 & 16.088 & 6.321 & 0.870 & 0.054 & 0.007 & 0.951 & 3.540 & 1.145 & 14.664 & 1.097 & 0.132 & 88 & 130 & 182 \\
\hline USGS-3 & 434 & 60 & 89 & 5900 & 7.7 & 2.845 & 0.041 & 0.014 & 55.220 & 19.409 & 0.358 & 0.006 & 0.046 & 0.245 & 1.262 & 1.124 & 57.528 & 0.960 & 0.253 & 54 & 105 & 103 \\
\hline \multicolumn{23}{|c|}{$\begin{array}{l}\text { Other } \\
\text { Geothermal } b\end{array}$} \\
\hline BLM $^{\mathrm{c}}$ & 123 & - & 93 & 3000 & 7.4 & 2.196 & 0.058 & 0.026 & 25.088 & 11.424 & 0.537 & 0.021 & 0.034 & 0.202 & 0.803 & 1.353 & 25.098 & 1.000 & 0.400 & 74 & 120 & 144 \\
\hline Crook $^{\mathrm{d}}$ & 165 & 45 & 97 & 5800 & 7.7 & 6.488 & 0.066 & 0.010 & 44.350 & 6.836 & 0.819 & 0.018 & 0.064 & 0.375 & 0.557 & 1.166 & 49.350 & 0.899 & 0.326 & 86 & 127 & 138 \\
\hline \multicolumn{23}{|l|}{ Private } \\
\hline $\begin{array}{l}155-26 \mathrm{E} \\
23 \mathrm{ABD} 1\end{array}$ & 110 & - & 29 & 4500 & 7.6 & 4.841 & 0.411 & 0.085 & 33.306 & 6.880 & 0.512 & 0.015 & - & 0.274 & 2.540 & 1.999 & 35.814 & 0.930 & 0.268 & 61 & - & - \\
\hline $\begin{array}{l}15 \mathrm{~S} 26 \mathrm{E} \\
23 \mathrm{DDD} 1\end{array}$ & 78 & - & 42 & 3900 & 7.1 & 5.191 & 0.658 & 0.127 & 28.001 & 5.394 & 0.460 & 0.016 & - & 0.158 & 2.754 & 1.187 & 31.020 & 0.903 & 0.237 & 58 & - & - \\
\hline \multicolumn{23}{|c|}{ irst perforations. } \\
\hline \multicolumn{23}{|c|}{ b. Temperature measured at surface. } \\
\hline \multicolumn{23}{|c|}{ c. This well was drilled in the 1920 's and is called the Bridge well by the USGS. } \\
\hline d. This & & & & referre & & it nams & arlier & cat & & & & & & & & & & & & & & \\
\hline
\end{tabular}




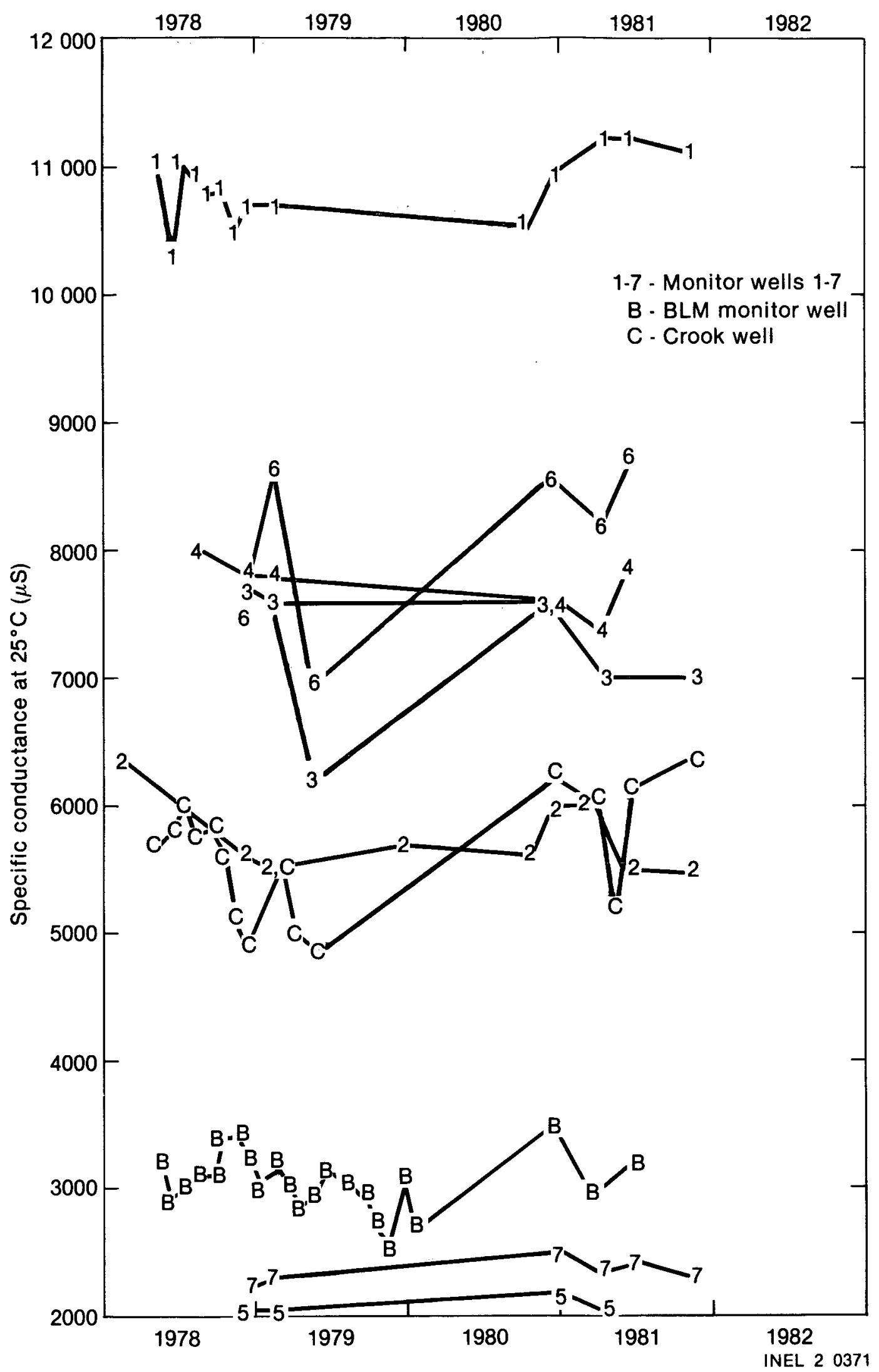

Figure 14. Specific conductance of water samples collected from selected wells at the Raft River geothermal site. 


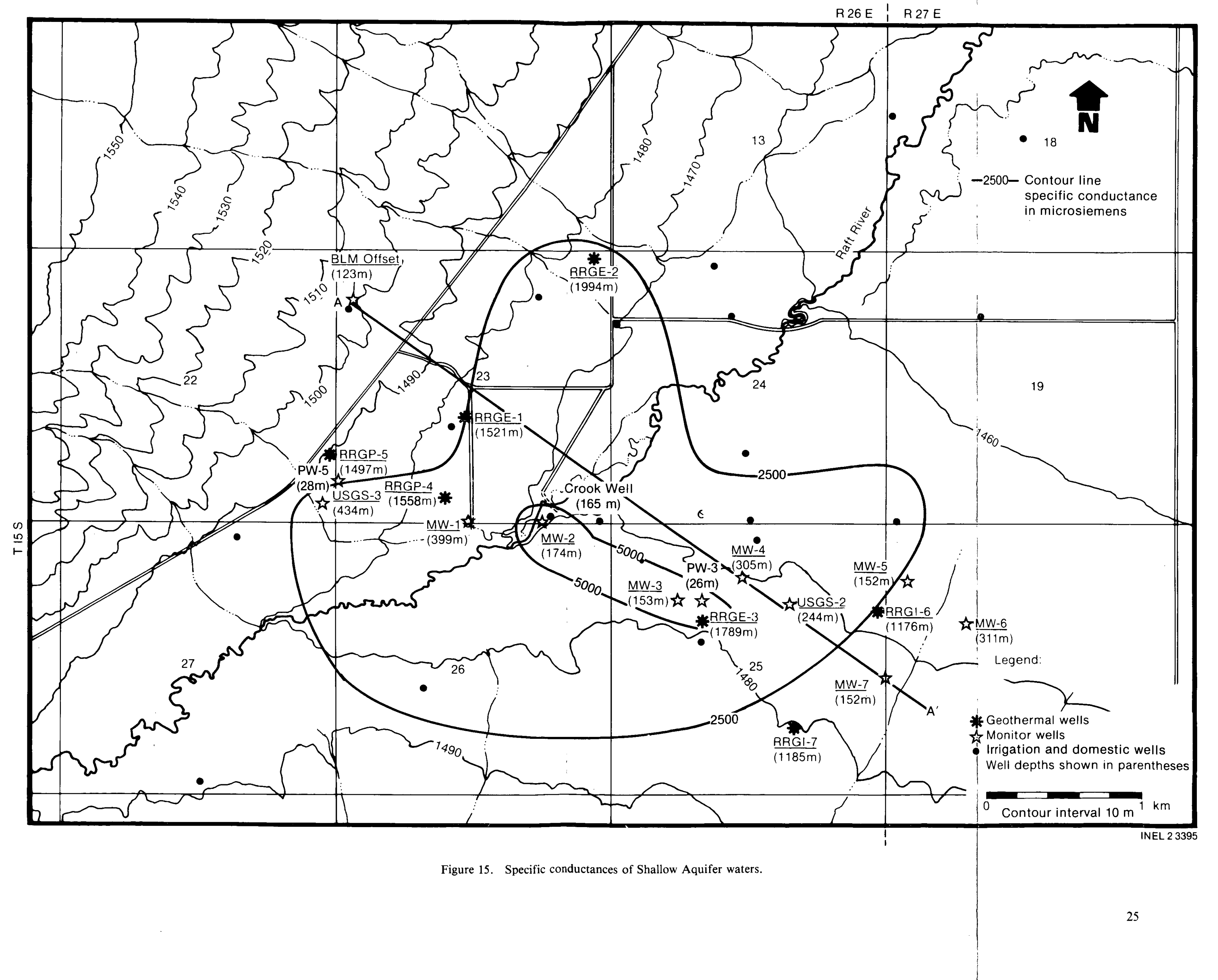




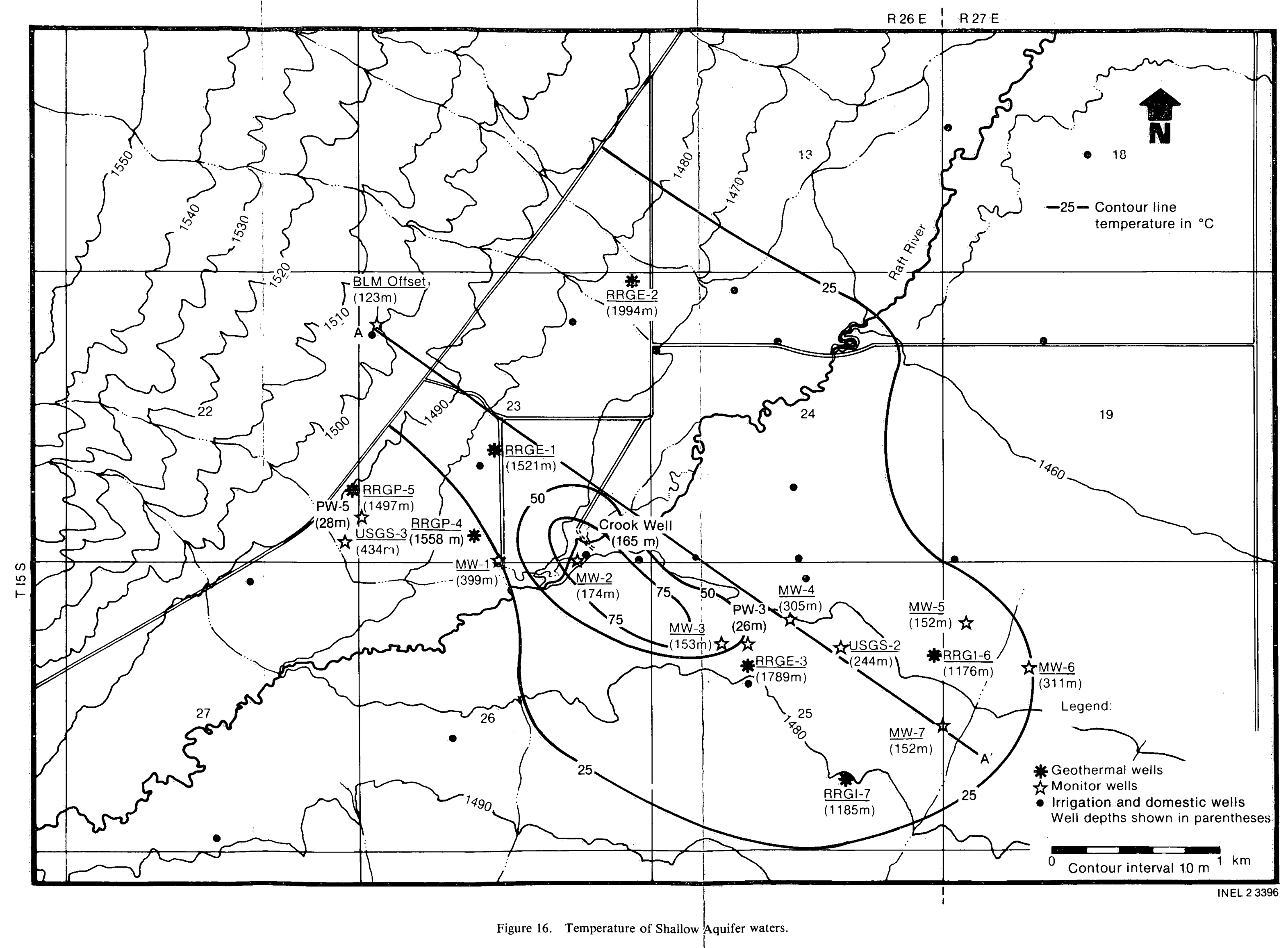




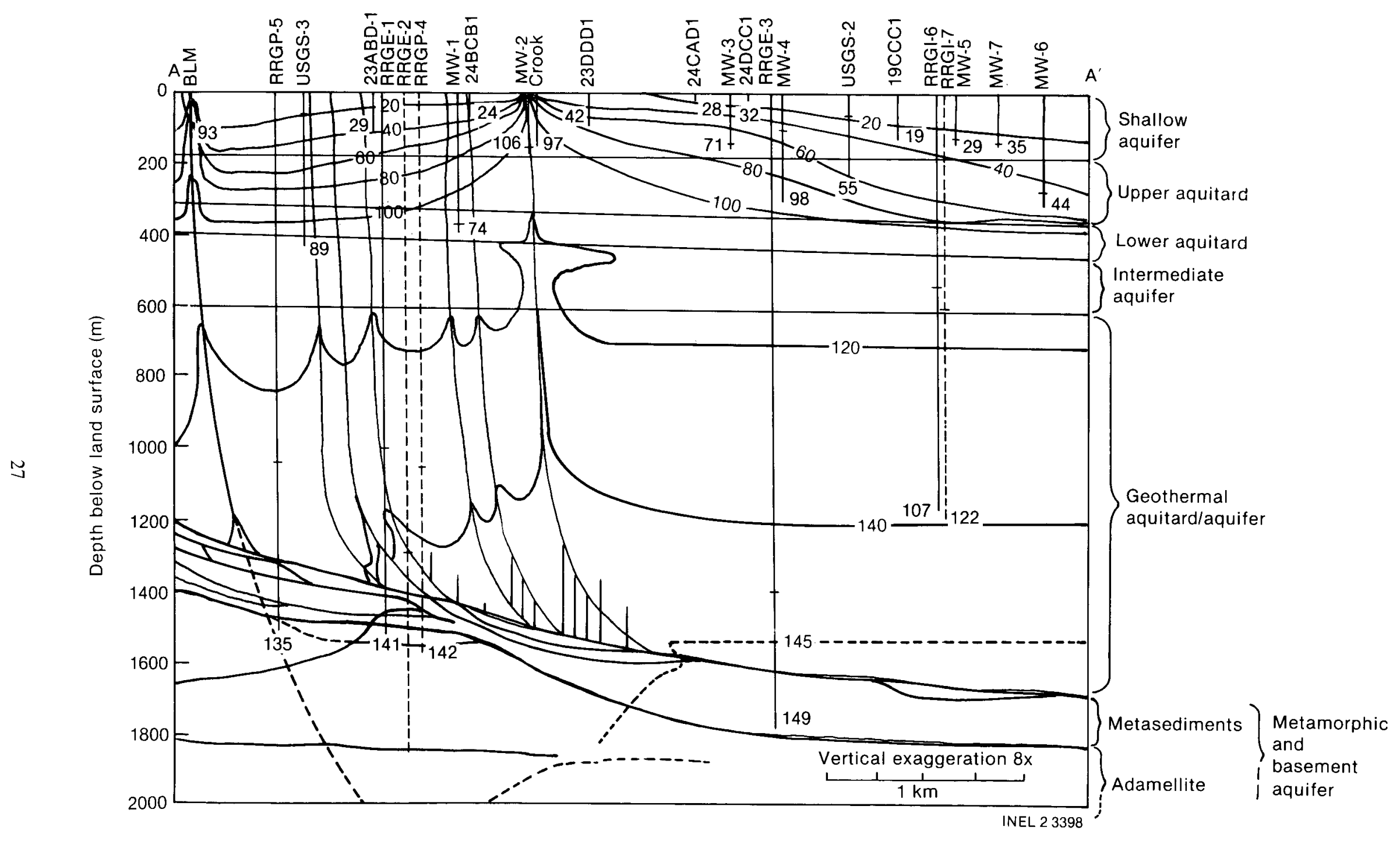

Figure 17. Cross Section $\mathrm{AA}^{\prime}$ depicting the conceptualized temperature $\left({ }^{\circ} \mathrm{C}\right)$ distribution. 


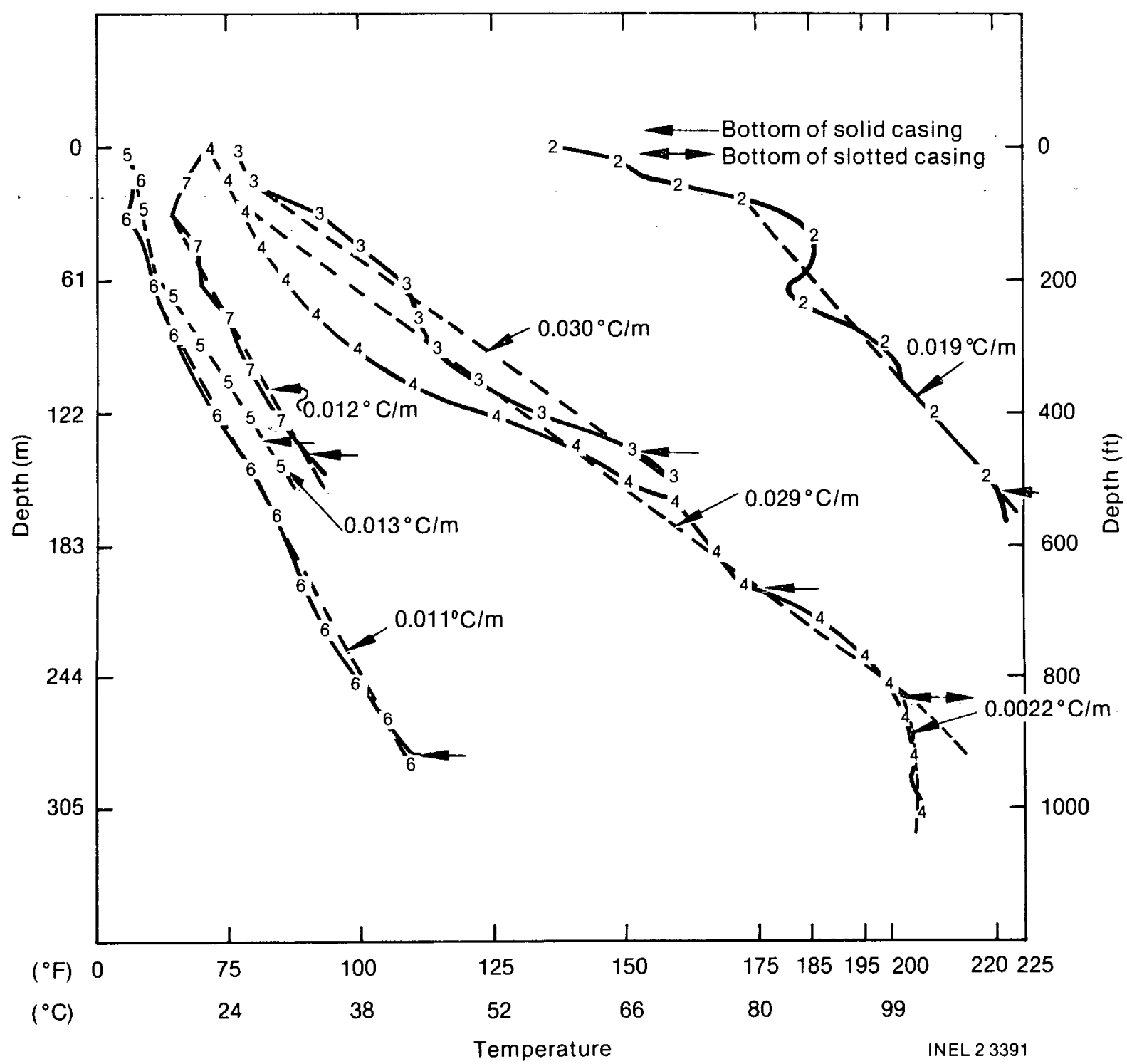

Figure 18. Shut-in temperature profiles for Raft River monitor wells.

interpreted as indicating that the area near $\mathrm{MW}-2$ is a significant discharge area for fluid originating at least as deep as the Intermediate Aquifer.

Figure 19 is a profile of the specific conductance. The specific conductance increases with depth in the Shallow Aquifer as a result of upward leakage from the Intermediate Aquifer. Surface recharge mixing with the geothermal leakage results in improved water quality near the land surface. Several other chemical constituents such as $\mathrm{Ca}, \mathrm{Mg}, \mathrm{Sr}, \mathrm{Na}, \mathrm{Li}, \mathrm{SO}_{4}$, and $\mathrm{Cl}$ have profile contours somewhat similar to those of specific conductance. The specific conductance distribution can thus be used as an indicator of the flow system geochemistry. Specific conductance increases downgradient in the flow system (upward in this discharge area), except in the Shallow Aquifer where mixing occurs with a fluid of lower specific conductance. 


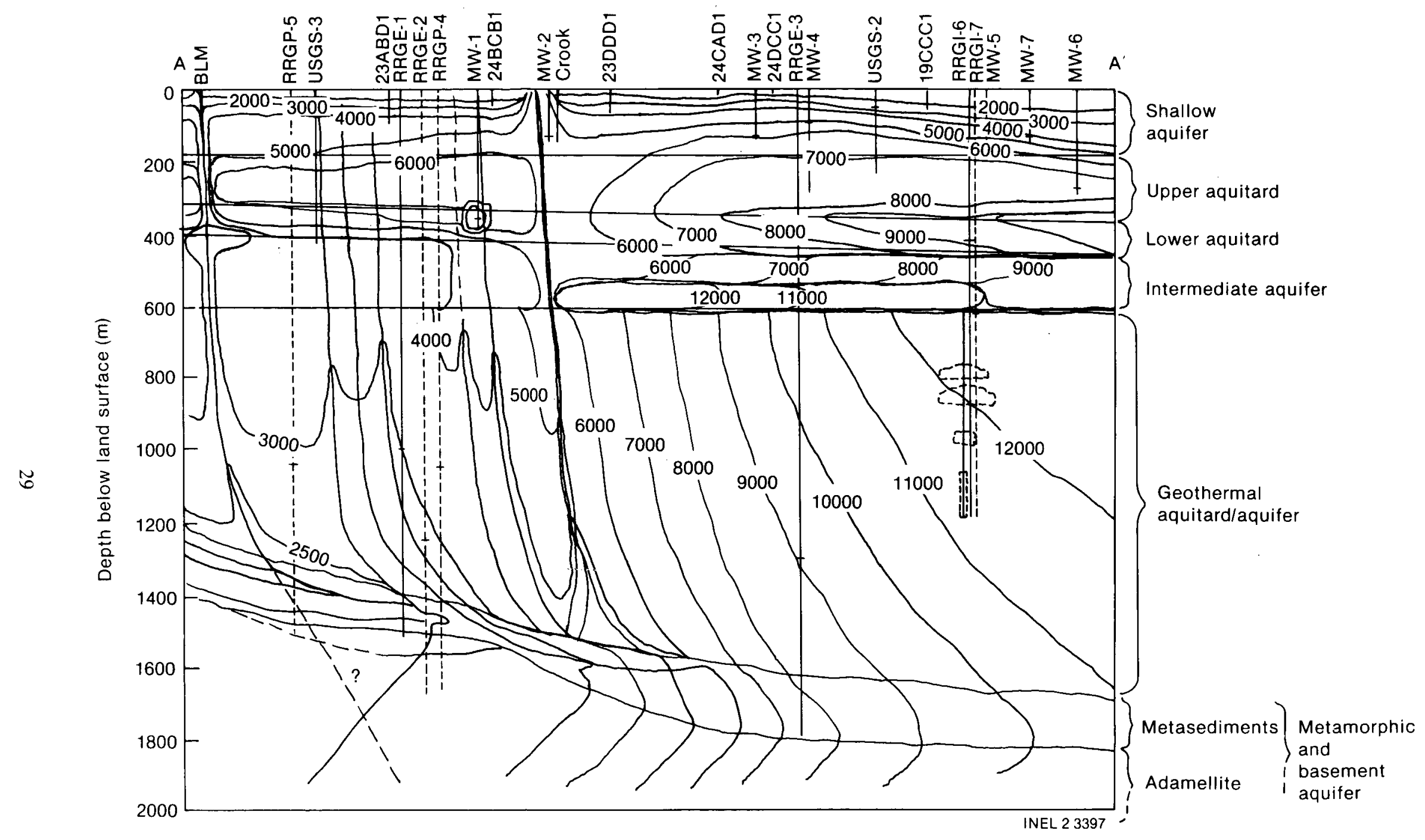

Figure 19. Cross Section $\mathrm{AA}^{\prime}$ depicting the conceptualized specific conductance $(\mu \mathrm{S})$ distribution. 


\section{UPPER AND LOWER AQUITARDS}

\section{Hydrology}

The aquitard separating the Shallow Aquifer from the Intermediate Aquifer (Figure 5) extends from -180 to $450 \mathrm{~m}$ below the land surface. The aquitard actually consists of 2 units. The Upper Aquitard from -180 to $335 \mathrm{~m}$ in depth is less permeable than the Shallow Aquifer, but much more permeable than the Lower Aquitard extending from 335 to $450 \mathrm{~m}$ in depth. In regard to potentiometric heads, the Lower Aquitard, for the most part, hydrologically isolates the underlying Intermediate Aquifer from the overlying Upper Aquitard and Shallow Aquifer. Geothermal fluid from the Intermediate Aquifer slowly seeps through the Lower Aquitard. The geologic log for RRGI-6 ${ }^{16}$ indicates that the Upper Aquitard contains some sand and gravel, but less than the Shallow Aquifer. The Lower Aquitard is basically a tuff. An EG\&G temperature log for RRGI-6 (Figure 20) (unpublished log 04/25/79) indicates a much larger thermal gradient from 335 to $425 \mathrm{~m}$ than in the overlying Upper Aquitard and underlying Intermediate Aquifer. The Lower Aquitard, and to a lesser degree the Upper Aquitard, act as thermal barriers for the geothermal system in the Intermediate Aquifer. The potentiometric surfaces for wells monitoring the Intermediate Aquifer (MW-1, -2, -4, USGS-3, and BLM offset) are much higher than for those wells monitoring the Upper Aquitard (MW-6) and Shallow Aquifer (PW-3, -5, MW-3, -5, -7, and USGS-2). Thus, the Lower Aquitard is a major hydrologic barrier to the upward migration of geothermal fluid from the Intermediate Aquifer. The dampened response to irrigation withdrawals of MW-6 (in comparison to MW-5) also results in part because of the lower permeability of the Upper Aquitard. The hydrologic and geologic data both support this division of the aquitard into upper and lower hydrologic units.

MW-4, which is only $305 \mathrm{~m}$ deep, is believed to be primarily monitoring the potentiometric head within the underlying Intermediate Aquifer although the well is completed within the Upper Aquitard. This probably results because of soft sediment faulting. Evidence of faulting in the vicinity is present in RRGE-3 where drilling fluid was lost at a rate of $34.7 \mathrm{~L} / \mathrm{s}$ in a $2.44 \mathrm{~m}$ zone at a depth of $1045 \mathrm{~m} .17$ Windows may exist through the tuff due to nondeposition or erosion; but, this appears to be less likely than faulting as a means of providing a hydrologic discontinuity through the Lower Aquitard. The major leakage from the Intermediate Aquifer to the Shallow Aquifer in the vicinity of $M W-2$ and -3 may result because of the intersection of a NNE trending fault(s) parallel to the Bridge Fault system (Figures 2 and 4) and NW trending fault(s) passing through the area near MW-4 and RRGE-3. Thus, the potentiometric response of MW-4 to the head changes presumed to be occurring in the Intermediate Aquifer probably results from faulting of the Lower Aquitard, although it could be due to nondeposition or erosion of the Lower Aquitard.

\section{Monitor Well Potentiometric Head Responses}

\author{
Monitor Well-6 (MW-6) \\ - Wellhead elevation-1469 m \\ - Well depth-311 m \\ - Open borehole-1195 to $1158 \mathrm{~m}$.
}

This monitor well, located near MW-5 south of the irrigated lands in the Raft River flood plain (Figure 1) is the only well which is monitoring solely the potentiometric head in the Upper Aquitard. Because of the relatively high vertical permeability of the Upper Aquitard, the potentiometric head response in MW-6 is typical of that for the Shallow Aquifer (Figure 21). It appears to correlate best in overall potentiometric head trends with MW-7, a $152 \mathrm{~m}$ deep well farther to the south. The potentiometric heads in this well exhibit a long-term decline of $0.70 \mathrm{~m} / \mathrm{yr}$ from 1979 to 1982 with maximum annual potentiometric declines due primarily to irrigation, ranging from 1.92 to $2.80 \mathrm{~m}$ in 1980 and 1979 , respectively. The similar annual potentiometric head fluctuations at MW-6 and -7 suggest some dampening of the Shallow Aquifer potentiometric head fluctuations as the pressure response passes through the Upper Aquitard to MW-6.

In 1982, the potentiometric head at MW-6 followed a typical rising trend until March 25 (Figure 12). The sharp potentiometric head 


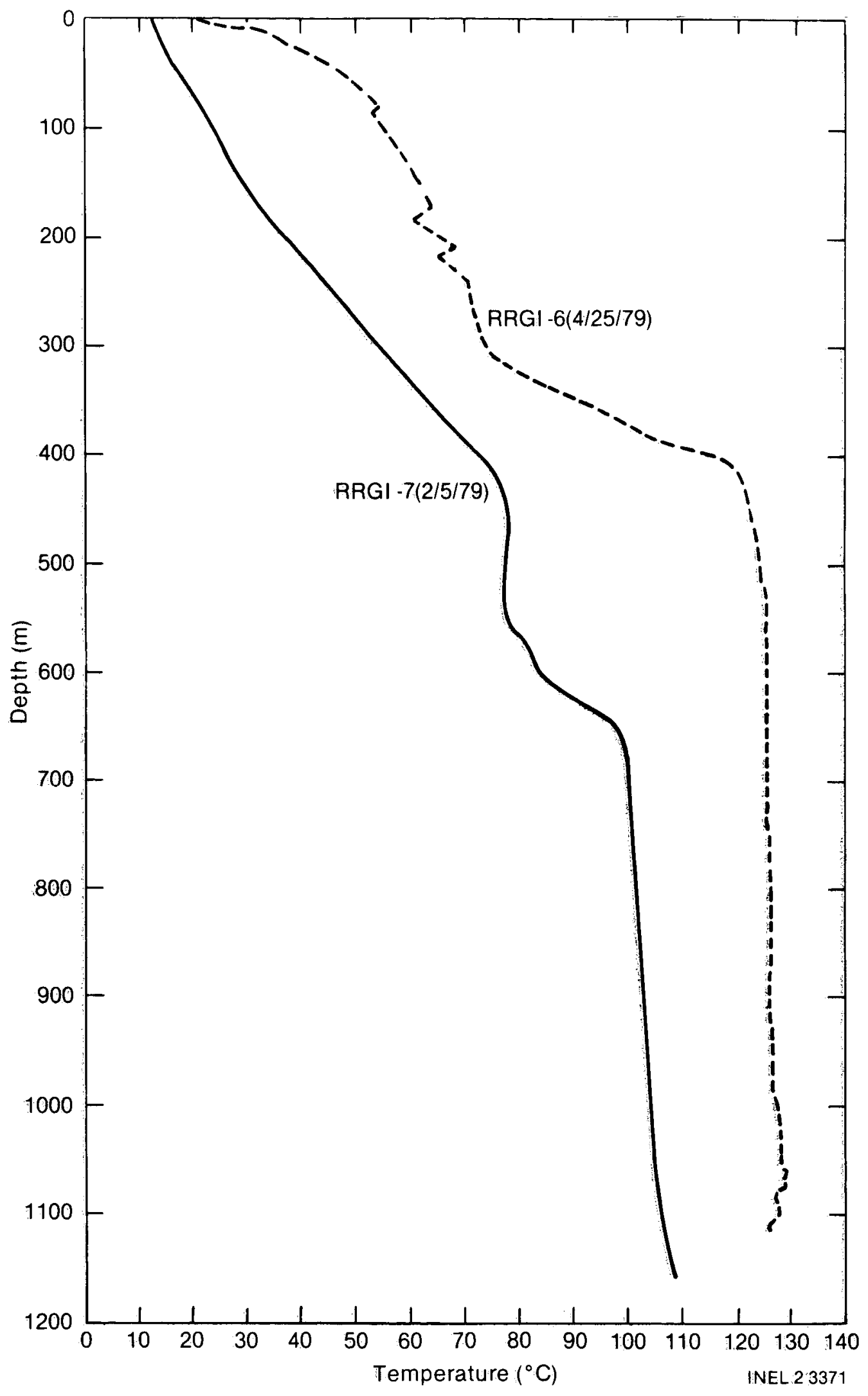

Figure 20. Temperature logs for RRGI-6 and -7. 


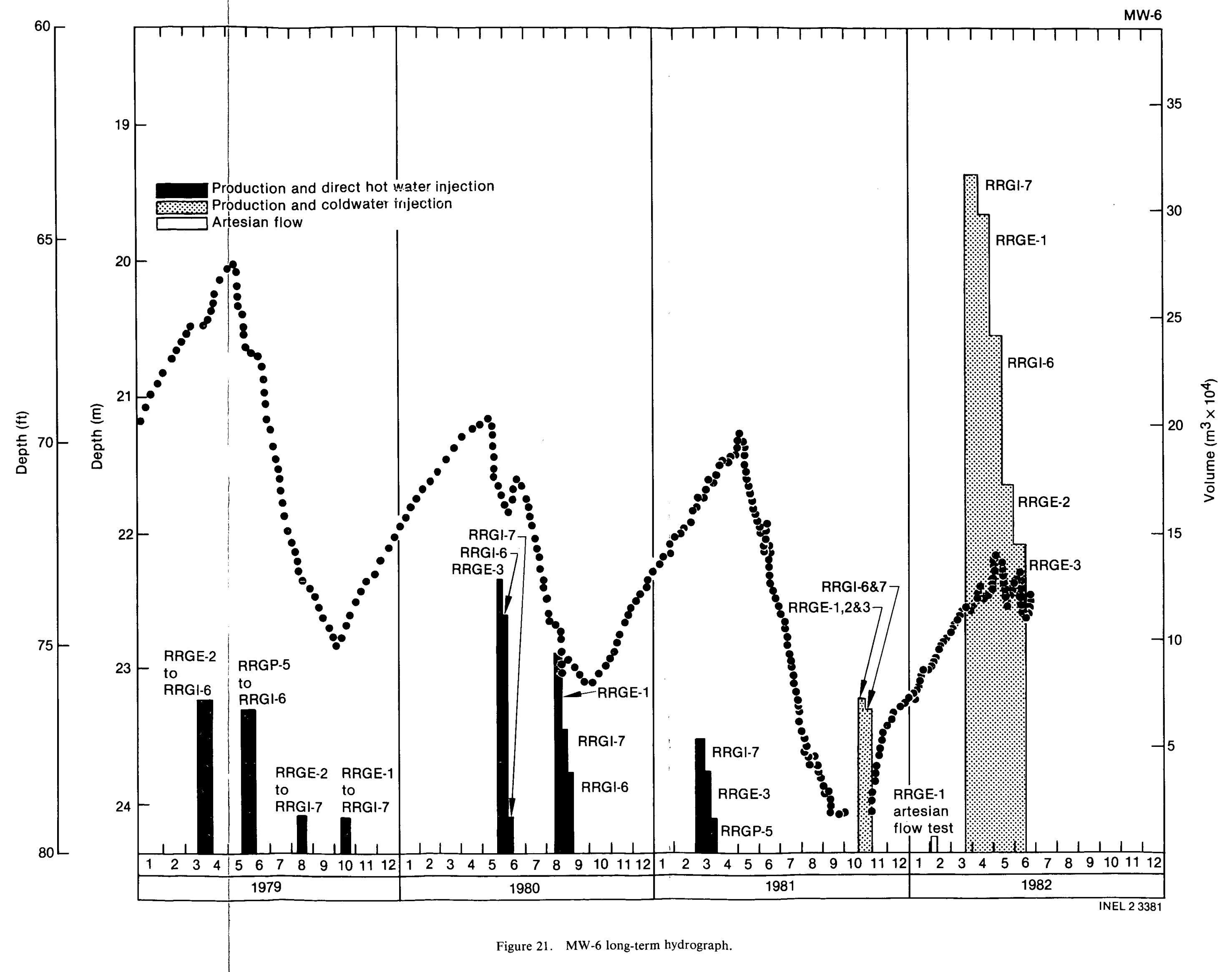


decline on March 25 coincides with the beginning of injection. From March 25 until June 15, injection continued, with numerous, interruptions lasting from a few hours to a few days. During this period, several declines and recoveries were observed; for example, there were declines on April 1 and 14 and recoveries on April 13, 22, and 23 . These declines and recoveries coincide with the startup and stoppage of injection periods. The general rising trend continued until May 7 , when a declining trend began with an abrupt potentiometric head decline coinciding with the beginning of injection. The sudden pressure rise on May 16 coincides again with the cessation of injection. Between May 16 and June 19 (end of record), interference from irrigation pumping makes it impossible to discern the potentiometric head fluctuations attributable to injection from those associated with irrigation. The overall declining trend between May 6 and June 19 is less distinctive than in previous years. The water level rise on June 15 through 17 coincides with the end of injection pumping.

\section{Geochemistry}

The geochemical characteristics of the fluid in the Upper Aquitard are affected by the upward leakage of geothermal fluid through the Lower Aquitard and the lateral flow of groundwater in both the Shallow Aquifer and Upper Aquitard. This lateral groundwater flow component is probably responsible for the depressed temperatures at depths of 180 and $220 \mathrm{~m}$ in the RRGI-6 temperature $\log$ (Figure 20). The Lower Aquitard contains groundwater derived from the Intermediate
Aquifer. The Lower Aquitard groundwater degrades in quality during upward migration.

The temperature of the groundwater in the aquitard decreases towards the surface as indicated in Figures 17, 18, and 20. The greatest thermal gradient presumably exists in unfaulted areas of the Lower Aquitard, probably near the MW-6 area (Figure 18). However, where the Lower Aquitard leaks significant quantities of geothermal fluid, such as near MW-2, the depth at which the maximum geothermal gradient occurs is probably less than that of the Lower Aquitard. The temperature regime in the Upper and Lower Aquitards is thus affected by convective and conductive transport of heat from the Intermediate Aquifer as well as lateral convective transport in the Upper Aquitard.

The specific conductance of the groundwater is indicated in the cross section in Figure 19. A high gradient in the specific conductance is presumed to occur as the groundwater migrates from the Intermediate Aquifer through the Lower Aquitard. This would result primarily from a low fluid flow rate, a relatively long residence time, and the fine-grained nature of the Lower Aquitard as compared to the Intermediate Aquifer. The long residence time facilitates the development of chemical equilibria in rock-water reactions, resulting in a general degradation of water quality. Dilution with local recharge results in an improved water quality near the upper portion of the Upper Aquitard. Thus, the distribution of specific conductance results from upward leakage of geothermal fluid, reaction of groundwater with the host rock, and dilution with locally-derived surface recharge. 


\section{INTERMEDIATE AQUIFER}

\section{Hydrology}

The Intermediate Aquifer is an areally-extensive sedimentary sand and gravel aquifer $\sim 130 \mathrm{~m}$ thick, penetrated by all production and injection wells between -450 and $580 \mathrm{~m}$. This aquifer has resulted in a loss of drilling fluid (RRGE-1), casing grouting problems (RRGE-1 and RRGI-4) and reversals in borehole temperature logs (RRGP-5, RRGI-6, and -7). Figure 20 contains temperature logs for RRGI-6 and -7. Because of injection of hot water $\left(120^{\circ} \mathrm{C}\right)$ into RRGI-6, 18 days prior to running the log, the loss of considerable injection fluid into the Intermediate Aquifer has probably modified the temperature and thermal gradients below $435 \mathrm{~m}$. However, since RRGI-7 is cased to $623 \mathrm{~m}$, with little injection prior to running the temperature $\log 103$ days after well completion, the temperatures logged are probably fairly representative of the actual formation fluid temperatures. The RRGI-7 temperature reversal (decreasing temperature with an increasing depth) between 457 and $562 \mathrm{~m}$ is the best criteria for defining the Intermediate Aquifer, since this aquifer is apparently so permeable vertically and horizontally that a density-induced circulation system has developed. This aquifer probably has the greatest transmissivity of any aquifer in the Raft River KGRA. Thus, the Intermediate Aquifer is a very important component of the geothermal flow system at Raft River.

The ground-water flow system in the Intermediate Aquifer is somewhat speculative. The following description, see Figure 5, is that as perceived by the authors. The Intermediate Aquifer is leaking geothermal fluid upward through the Lower Aquitard via porous media flow and faults breaching the aquitard (e.g., BLM well, Crook Well, MW-2, and -4 areas). The areal extent of this discharge is not completely known; but probably includes the Narrows and the Raft River flood plain at least as far down gradient as MW-2. The northeastward extent of the discharge area for the Intermediate Aquifer is not known since it depends on the unknown areal extent and hydrologic characteristics of the Intermediate Aquifer and the aquitards.

Significant recharge to the aquifer is presumed to occur to the west and northwest under the Jim
Sage Mountains, or possibly the Albion Range, due to downward percolating snowmelt and rainfall. Vertical migration of groundwater is presumably enhanced by anticlinal upwarping of the Jim Sage Mountains. This upwarping can be expected to produce vertically-oriented tension cracks or faults, possibly from within the basement adamellite to the surface. Preliminary mapping 12 indicates N-S oriented faults in the Jim Sage Mountains (Figure 4). These faults are also presumed to serve as conduits for flow from the Intermediate Aquifer to the underlying Metamorphic and Basement Geothermal Aquifer. At present, it is believed that the Jim Sage Mountains serve as a primary source of recharge to the Intermediate Aquifer. The Albion Range may also be a recharge area for the Geothermal system. For whatever reason, there is no evidence indicating that significant recharge to the Intermediate Aquifer is occurring to the south, near the Raft River Mountains, or to the east, near the Black Pine Mountains. Lateral flow in the Intermediate Aquifer from under the Jim Sage Mountains is probably directed toward the topographicallylower Raft River flood plain. Upward heat flow from the basement rocks can be expected to increase the temperature of the Intermediate Aquifer ground-water from the recharge to discharge areas.

The Intermediate Aquifer is also recharged in the vicinity of the Raft River flood plain by upward leakage from the underlying geothermal system within and immediately above the Metamorphic and Basement Geothermal Aquifer. This upward leakage occurs primarily along faults such as those mapped by 12 (Figure 4) and by upward seepage through the underlying sedimentary rocks. This upward leakage from the Metamorphic and Basement Geothermal Aquifer results in an elevated temperature in the Intermediate Aquifer as well as a deterioration in the water quality. This upward-directed recharge is probably near a maximum in the vicinity of MW-2. This influx of hot water in localized areas, primarily near faults, has facilitated the development of a thermal convective system in the Intermediate Aquifer, which results in a reversal in the thermal gradient (Figure 20, RRGI-7). The maximum temperature near the top of the Intermediate Aquifer in various boreholes should decrease away from major leaky faults. This 
characteristic, as well as the thermal gradient in the overlying aquitards, could probably be used to locate the leaking subsurface faults (Figures 17, 20). The upward recharge of geothermal fluid to the Intermediate Aquifer is a significant aspect of the geothermal flow system in the Raft River KGRA.

There are no monitor wells completed solely within the Intermediate Aquifer. The BLM well, which is used to obtain samples for water quality determinations, and the BLM offset well, which is used to obtain potentiometric head data, are presumed to be monitoring the Intermediate Aquifer via a permeable fault. Both the potentiometric head regime and the water quality data are believed to be indicative of the Intermediate Aquifer. However, both water quality and potentiometric head data may be modified in the $324 \mathrm{~m}$ interval separating the BLM well and BLM offset well from the top of the Intermediate Aquifer. In addition, if the fault encountered by the BLM well and BLM offset well extends below the Intermediate Aquifer and leaks geothermal fluid from the deep geothermal system up into the Intermediate Aquifer, the water quality and possibly the potentiometric head data collected from the BLM well and BLM offset well may be indicative of the deep geothermal fluid rather than that of the Intermediate Aquifer. There is, thus, some doubt especially regarding the significance of the water quality and, to a lesser extent, the potentiometric head data obtained from the BLM well and BLM offset well.

The USGS-3 well is the only monitor well completed into the conglomerate of the Intermediate Aquifer. Thus, the potential exists for monitoring the Intermediate Aquifer. The wellhead pressure of $\sim 1.4 \mathrm{~m}(13.8 \mathrm{kPa})$ favors a hydraulic connection to the Intermediate Aquifer since the water table is $\sim 26 \mathrm{~m}$ below land surface, while the geothermal production wells have wellhead pressures of $\sim 100 \mathrm{~m}(965 \mathrm{kPa})$. However, this well has only $60 \mathrm{~m}$ of casing, thereby resulting in a $374 \mathrm{~m}$ uncased wellbore. Fluid circulation from the bottom of the wellbore in the Intermediate Aquifer to the Upper Aquitard and Shallow Aquifer can be presumed to occur, since the potentiometric head is greater in the Intermediate Aquifer than in the overlying hydrologic units. This condition would result in a wellhead potentiometric head at USGS-3 which is less than that in the Intermediate Aquifer along with dampened head changes in comparison to those actually resulting in the Intermediate Aquifer. The water quality data should be somewhat representative of that in the Intermediate Aquifer; however, the lowering of the wellhead pressure to obtain a free flow sample for water quality determination can induce fluid migration into the wellbore from the upper uncased borehole. This may result in a water sample not representative of the groundwater normally within the wellbore.

MW-1, which is $399 \mathrm{~m}$ deep, penetrates into the tuff of the Lower Aquitard and perhaps penetrates into the upper portion of the Intermediate Aquifer. The wellhead pressure of $-2.3 \mathrm{~m}$ $(230 \mathrm{kPa})$ is the highest of all monitor wells and has a potentiometric surface $\sim 1.3 \mathrm{~m}(12.8 \mathrm{kPa})$ higher than the nearby USGS-3 well (after compensating for elevation differences between the wells). Likewise MW-1 has a potentiometric surface $20 \mathrm{~m} \mathrm{(196} \mathrm{kPa)}$ above that of MW-2. The differences in the potentiometric surfaces between MW-1, -2 , and USGS- 3 could result due to head losses attributable to the flow of water in the wellbore of USGS-3, possible plugging of the wellbore, and due to head losses attributable to the flow of groundwater in the fault(s) supplying water to MW-2 and the Crook well. The Crook well is permitted to free flow continually, further depressing the absolute potentiometric surface and changes in the potentiometric head at MW-2. The high potentiometric surface at MW-1 could also result if significant leakage from the deep geothermal system were occurring near MW-1. A combination of the above explanations is also possible. A definitive explanation cannot be offered to explain the large difference in the potentiometric surfaces at USGS-3, MW-1, and $\mathbf{- 2}$.

Information as to whether MW-1 monitors the Lower Aquitard and/or the Intermediate Aquifer can be obtained from potentiometric head fluctuations and water quality data. The potentiometric head fluctuations, Figure 22, suggest MW-1 monitors the Intermediate Aquifer, whereas the water quality data (Table 3), suggest the fluid is obtained from a near-stagnant ground-water body above the Lower Aquitard. These apparently contradictory conditions could result if the well obtains fluid from a unit of rock hydrologicallyisolated horizontally by near-vertical permeable faults on the sides of the unit with the highlytransmissive Intermediate Aquifer below. Such a 


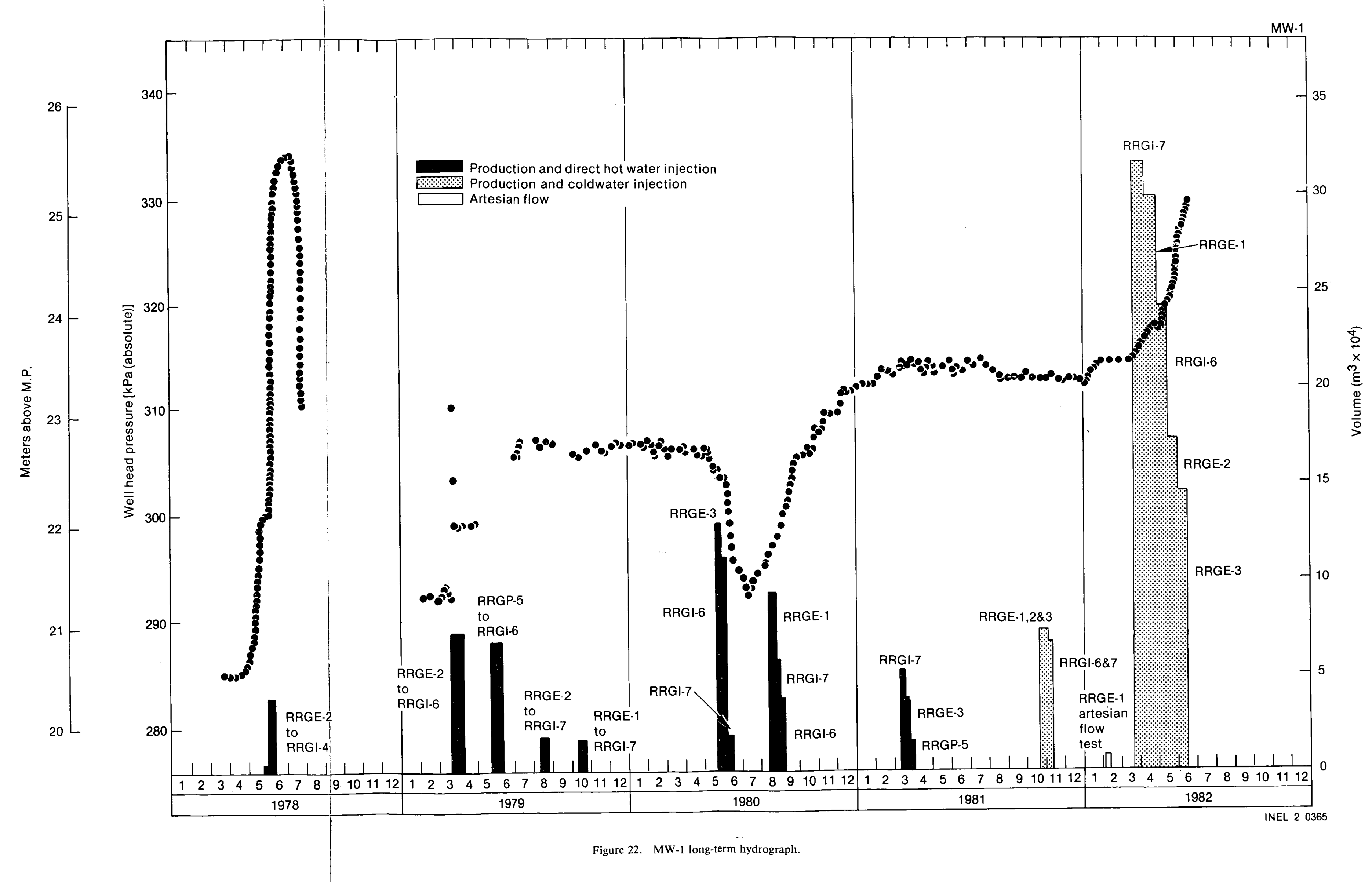


condition would tend to minimize horizontal head differences between faults hydraulically-connected to the Intermediate Aquifer. The low lateral and vertical hydraulic gradients would reduce flow velocities, increase the fluid residence time, and thus result in a general degradation in water quality. Thus, the hydrologic and geochemical conditions near MW-1 are somewhat of an enigma, possibly resulting from hydrologic isolation due to faulting.

MW-2 and the Crook well, which are 174 and $165 \mathrm{~m}$ deep, respectively, are believed to be monitoring modified versions of the potentiometric head fluctuations and water quality of the Intermediate Aquifer. The potentiometric head, and the fluctuations thereof, are suppressed due to head losses in the fault system as a result of upward flow to both the Crook well, which is permitted to free flow at a varying rate, and to natural seepage into the Shallow Aquifer. Modifying chemical reactions may also be occurring while the fluid is in transit from the Intermediate Aquifer to MW-2 and the Crook well. Thus, MW-2 data must be used with discretion in regard to the absolute potentiometric head and fluctuations thereof, as well as water quality parameters.

MW-4, like MW-2, is also presumed to be monitoring modified versions of the potentiometric head and fluctuations thereof, as well as the water quality within the Intermediate Aquifer. These data must also be used with discretion.

\section{Monitor Well Potentiometric Head Responses}

\section{Monitor Well-4 (MW-4)}

- Wellhead elevation-1468 m

- Well depth-305 m

- Slotted casing-1243 to $1214 \mathrm{~m}$

- Open borehole-1214 to $1163 \mathrm{~m}$.

This monitor well is one of five wells whose potentiometric heads are largely indicative of those in the Intermediate Aquifer. MW-4 is located on a sideslope just above the Raft River irrigated flood plain (Figure 1). The potentiometric head responses in MW-4 are complex
(Figure 23). Significant potentiometric head increases have resulted due to injection in March and May 1979, May 1980, October 1981, and March, April, May, and June 1982. The magnitude of the potentiometric head buildup is related to the injection rate and duration of the test at RRGI-6. This indicates that a relatively good hydraulic communication exists between RRGI-6 and the Intermediate Aquifer, which is presumed to be monitored, at least in part, by MW-4. Seasonal trends are not evident during 1979 and 1980; however, they are evident in 1981. There appears to be a net potentiometric head increase during 1979 and 1980 . This response, and those of MW-1, -2, USGS-3, BLM offset, and BLM well, are in contrast to most of the other monitor wells which have declining potentiometric heads. This may have resulted because the RRGI- 6 injection operations during both 1979 and 1980 occurred during the season when water-level drawdown due to irrigation normally occurs. The effects of these long-term, high-volume injection tests appear to counter the impacts of seasonal drawdown by increasing the potentiometric surface. After these tests, there was a rapid falloff/drawdown until the irrigation pumps were turned off at the end of September. At this point, the normal autumn recharge began. Thus fall recharge began at a higher potentiometric head than in the previous year. In addition, pumpage of the Crook well for greenhouse operations ceased in November 1980. This may have resulted in an increased potentiometric head in the Intermediate Aquifer. These phenomona probably account for the general upward trend during 1980. Very little injection at RRGI-6 occurred in 1981; consequently, the water level follows the normal seasonal pattern typical of the Shallow Aquifer and the Upper Aquitard, with which this well is hydraulically-connected. Thus, it appears that sustained injection into RRGI-6 results in a potentiometric head increase in the Intermediate Aquifer, resulting in a significant increase in the potentiometric head in MW-4. The significance of this projected response as a potentially-degrading factor to Shallow Aquifer water quality is difficult to quantify. If long-term injection into RRGI-6 occurred, it would be expected that fluids in the Intermediate Aquifer would move up into the Shallow Aquifer at a greater rate than that without injection. It is important to note, however, that the undisturbed water-bearing zones intercepted by MW-4 initially contained water of poor quality, presumably because natural communication with the Intermediate Aquifer has existed historically. 


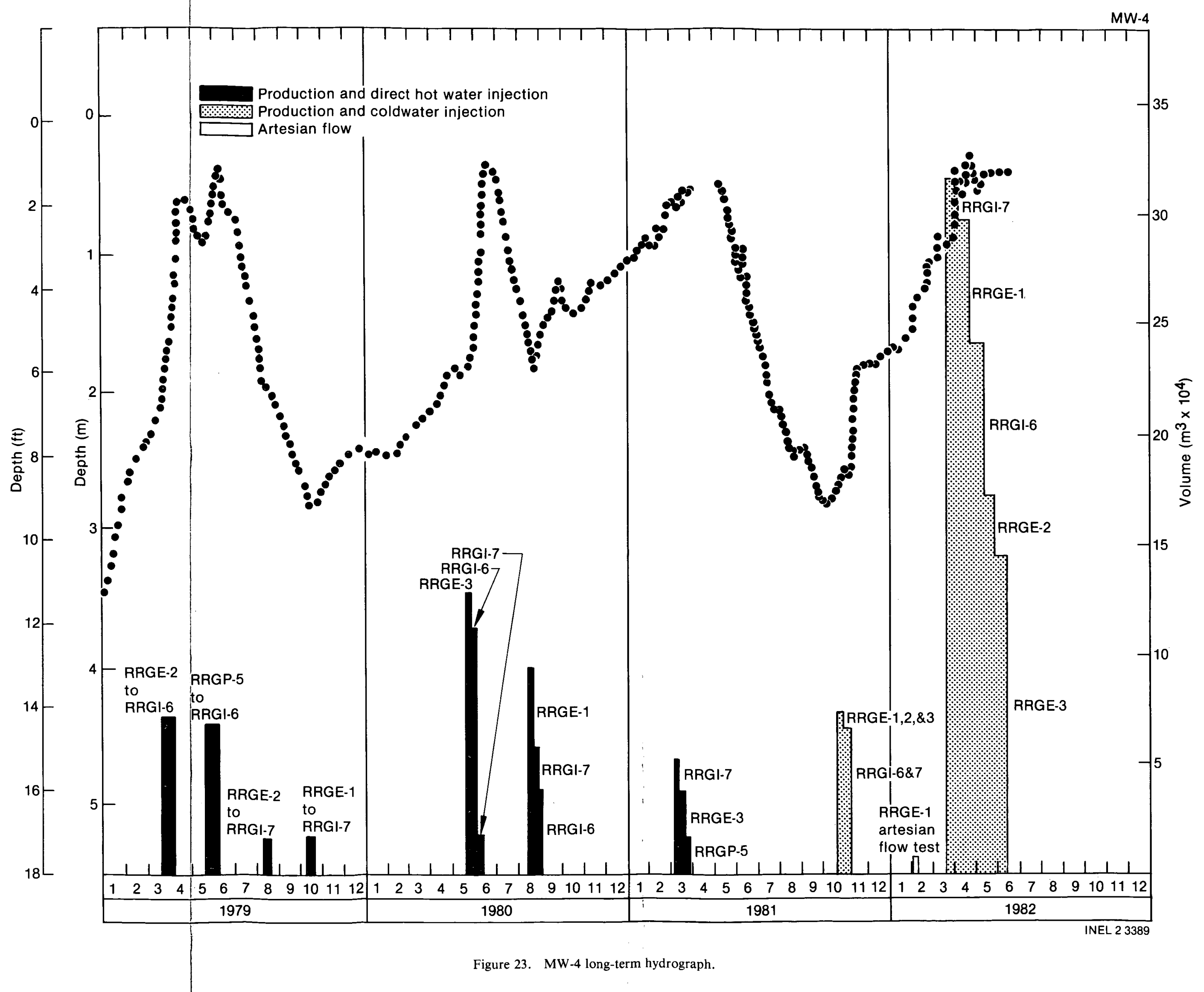


In 1982, the potentiometric head in MW-4 increased during January, February, and the first half of March (from 1.70 to $0.85 \mathrm{~m}$ depth to water level, Figure 24). A slight decline in the potentiometric head occurred at mid-March. On March 26, the potentiometric head declined abruptly by $\sim 0.037 \mathrm{~m}$. This decline was followed by an abrupt potentiometric head rise of $0.61 \mathrm{~m}$. At that point, the master valve was closed and the digiquartz pressure transducer was installed. Unfortunately, the digiquartz pressure transducer data were significantly affected by the atmospheric pressure changes and thus, do not provide accurate potentiometric head data. The potentiometric head decline, prior to the buildup associated with injection, could result because of a time lag in transmitting the pressure buildup in the
Intermediate Aquifer, due to injection, through the Lower into the Upper Aquitard. There are undoubtably other phenomena that could also produce the observed potentiometric head pattern. The observed pattern was similar to that of previous years.

\section{Monitor Well-2 (MW-2)}

- Wellhead elevation-1474 m

- Well depth-174 m

- Slotted casing-1320 to $1308 \mathrm{~m}$

- Open borehole-1308 to $1300 \mathrm{~m}$.

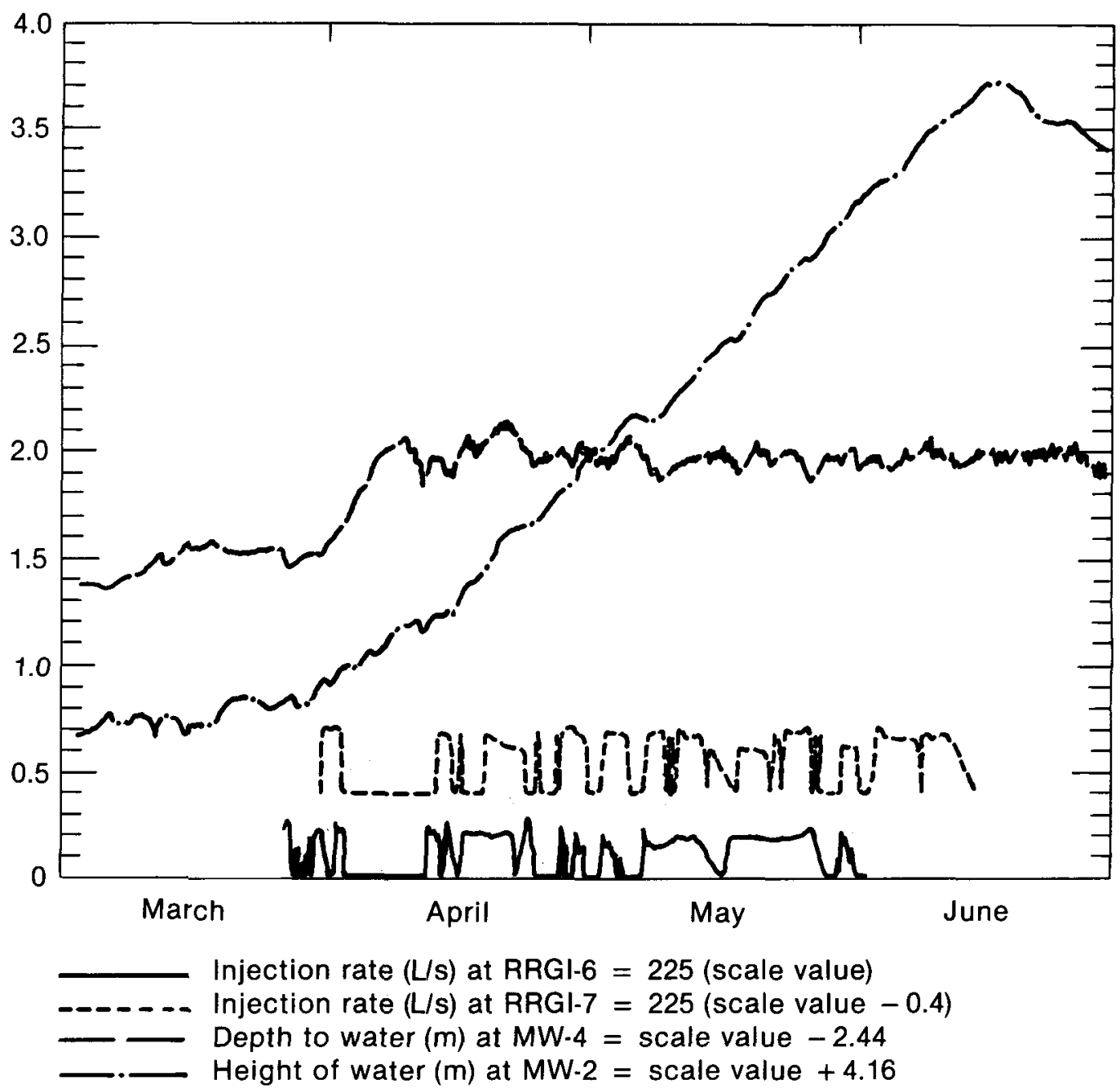

INEL 23443

Figure 24. Hydrographs for MW-2, -4, and injection rates for RRGI-6 and -7 from March to June 1982. 
MW-2 was drilled near the Crook geothermal well to monitor the effects of geothermal pumping and injection on the Crook well, shallow irrigation wells, and domestic wells (Figure 1). The Crook well was previously used to supply geothermal water (average temperature $96^{\circ} \mathrm{C}$ ) for greenhouse heating. Greenhouse operations ceased in November 1980 and the well has been allowed to free flow ever since. MW- 2 has a better hydraulic connection with the Crook well aquifer than MW-1. Deviations in response between MW-1 and -2 are expected since MW-2 (174 m deep) is $200 \mathrm{~m}$ from the Crook well ( $126 \mathrm{~m}$ deep), while MW-1 (399 $\mathrm{m}$ deep) is about $800 \mathrm{~m}$ from the Crook well.

Unlike MW-1, the potentiometric head in MW-2 exhibits some response to seasonal potentiometric head drawdown in the Shallow Aquifer (Figure 25). A slight downward potentiometric head trend in 1981 is apparent from early May through September, followed by a gradual recovery in the autumn. This seasonal pattern is associated with natural seasonal recharge and with irrigation pumpage. This potentiometric head response is not unusual with a fault-controlled leaky aquifer. The two brief pump tests of the Crook well in 1981 resulted in immediate and very rapid potentiometric head declines at MW-2. When the pump tests were terminated, recovery was also very rapid. The potentiometric head increase in August 1981 is due to a decline in irrigation pumping. This is supported by comparing these data with the potentiometric heads at PW-3.

The long-term potentiometric head trend at MW-2 was significantly affected by the operation of the Crook well. Because the time of greatest need for greenhouse heating is during the cooler seasons, October 1979 through March 1980 was the period of greatest Crook well pumping and consequently the lowest potentiometric heads at MW-2. Each sharp decline in the potentiometric head at MW-2 can be correlated to increased pumping activity at the Crook well.

During the first quarter of 1982, the potentiometric head at MW-2 increased (Figure 26). A more distinctive rise started at the end of March. This increase in potentiometric heads coincides with the beginning of the injection at RRGI-6 and -7 . The wellhead pressure increased from $13.7 \mathrm{~m}$ $(133.7 \mathrm{kPa})$ at the beginning of injection to $16.5 \mathrm{~m}(162 \mathrm{kPa})$ at the end of the injection on June 15 , a rise of $2.8 \mathrm{~m}(27.4 \mathrm{kPa})$. No rise is observed during the temporary termination of injection at RRGI-6. However, a continuous rise is observed when injection proceeds uninterrupted. The wellhead pressure of $15.5 \mathrm{~m}$ $(162 \mathrm{kPa})$ recorded at the end of injection is the highest level observed in MW-2. The previous high wellhead pressure was at $13.0 \mathrm{~m}(137.2 \mathrm{kPa})$, recorded in April 1981. The $2.8 \mathrm{~m}(27.4 \mathrm{kPa})$ buildup due to injection in 1982 was the largest response noted to date in MW-2; it presumably is somewhat indicative of the pressure buildup in the Intermediate Aquifer.

\section{Monitor Well-1 (MW-1)}

- Wellhead elevation-1475 m

- Well depth-399 m

- Open borehole-1106 to $1076 \mathrm{~m}$.

MW-1 was drilled near RRGI-4 for the purpose of monitoring the impacts of injection tests on local irrigation and domestic wells (Figure 1). Comparisons of well locations and well logs with known fault systems indicate that USGS-3 and RRGI-4 probably penetrate the same fracture system, while MW-1 probably penetrates unfractured rock adjacent to the fracture system.18

The potentiometric head at MW-1 (Figure 22) has remained fairly constant since injection into RRGI-4, and withdrawals from the Crook well and RRGE-3 have been minimal. Throughout autumn and winter of 1979 and spring of 1980 , wellhead pressure remained fairly constant, averaging about $31.5 \mathrm{~m}(308 \mathrm{kPa})$. During the summer of 1980, a decline in wellhead pressure of $1.74 \mathrm{~m}(17 \mathrm{kPa})$ resulted. This decline correlates with withdrawals from RRGE-3. After RRGE-3 pumping ceased, the wellhead pressure increased by late October to its previous average of about $31.6 \mathrm{~m}(309 \mathrm{kPa})$. Shortly after this, pumping of the Crook well ceased. This resulted in the average wellhead pressure increasing to about $31.9 \mathrm{~m}$ $(312 \mathrm{kPa})$. The erratic wellhead pressure pattern in the spring of 1979 is due to flow tests conducted at MW-1. The limited data from 1978 show recovery at MW-1 after a flow test of that well. This was followed by a very rapid increase in wellhead pressure $3.47 \mathrm{~m}(34 \mathrm{kPa})$ associated with the injection test at RRGI-4. Partial recovery data indicate a rapid decline of this pressure buildup following termination of the injection test. Thus, 


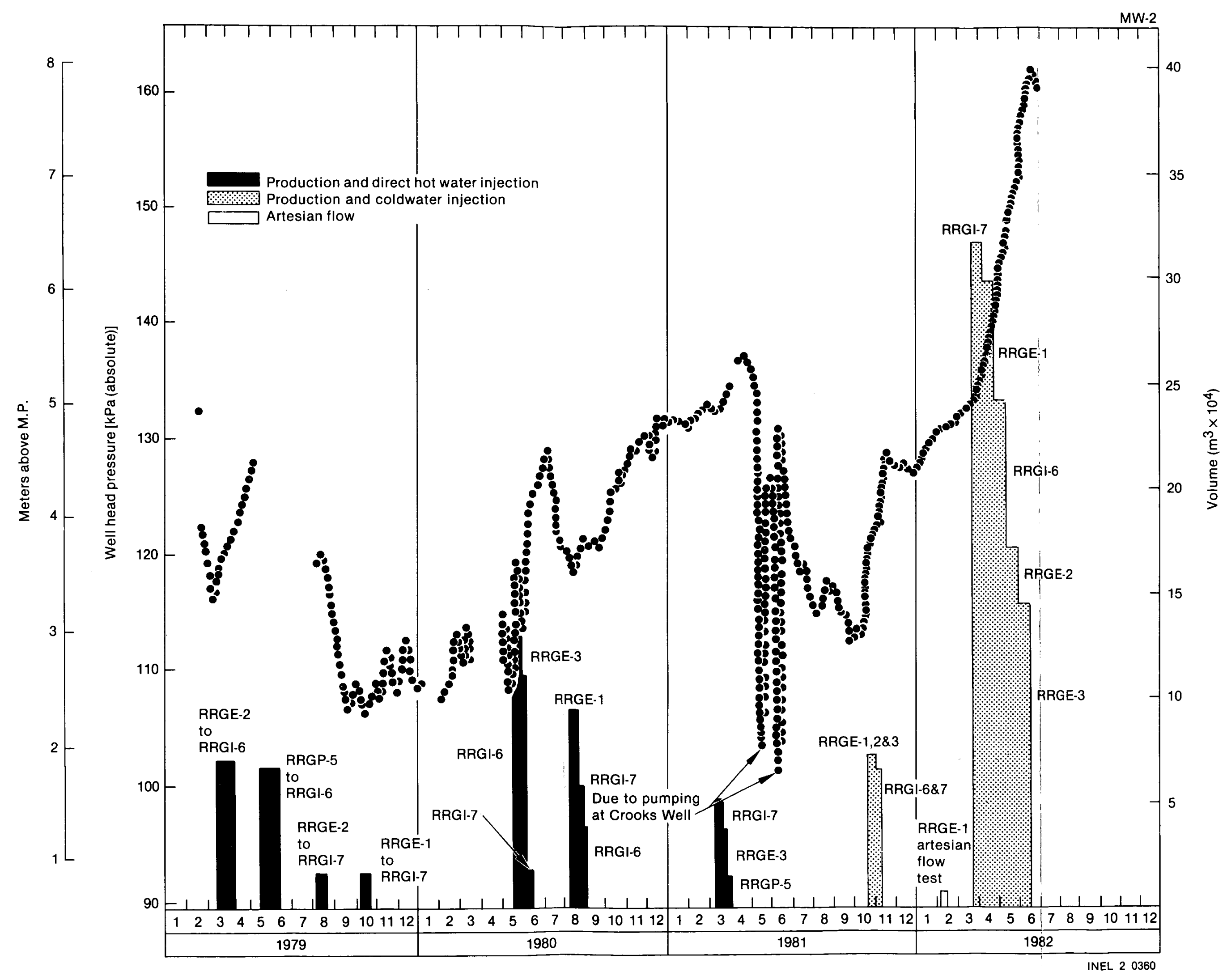

Figure 25. MW-2 long-term hydrograph. 

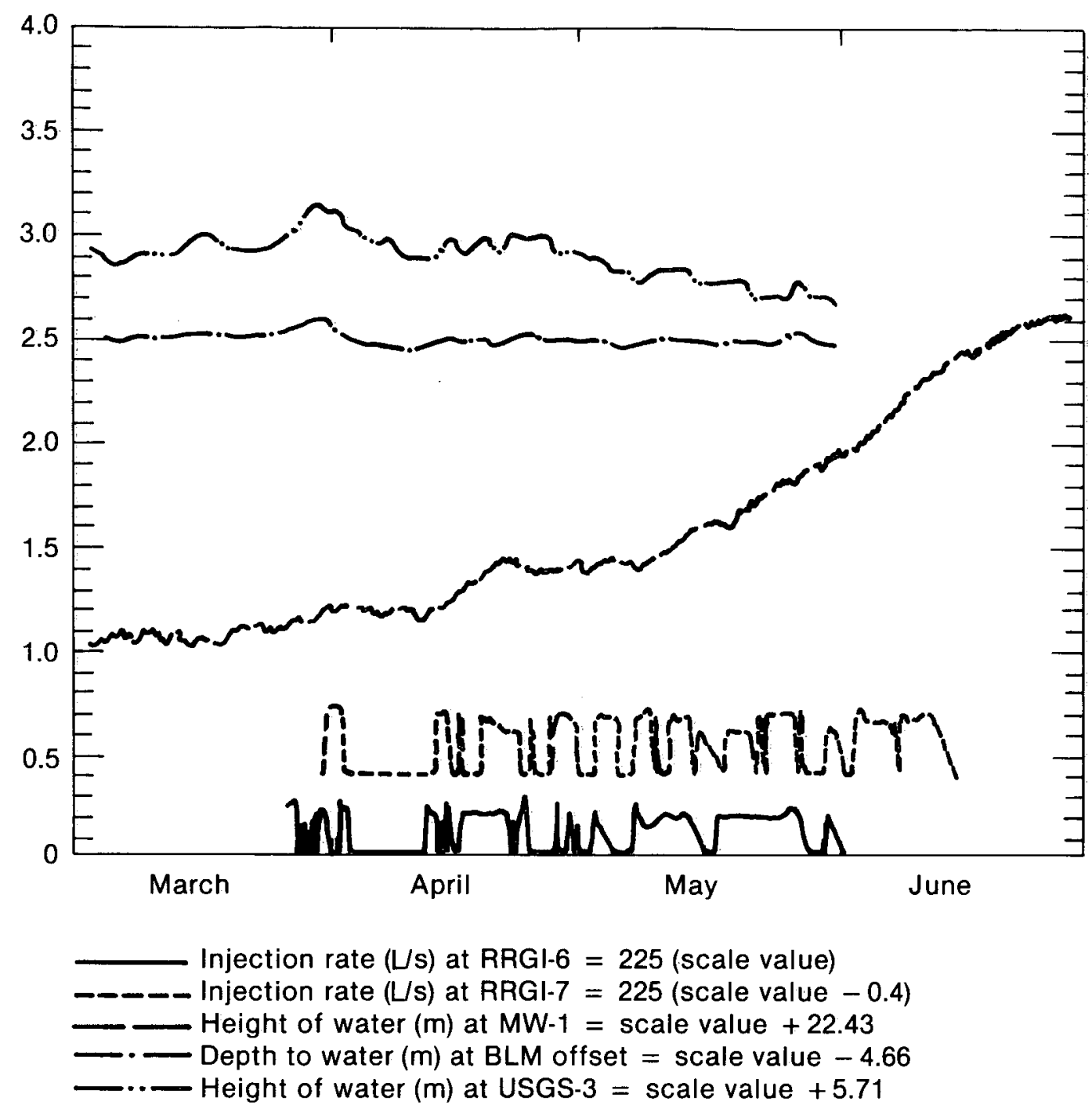

INEL 23444

Figure 26. Hydrographs for MW-1, USGS-3, BLM offset and injection rates for RRGI-6 and -7 from March to June 1982.

prior to 1982 , MW-1 has been affected by injection into RRGI-4, production from RRGE-3, and Crook well.

During the first quarter of 1982 (Figure 26) the wellhead pressure at MW-1 was progressively rising. This pressure increase was similar to the rise observed in 1981. A more distinctive wellhead pressure rise was observed between April 14 and 22 which coincided with extensive injection pumping into the RRGI-6 and -7 wells. From April 22 until May 8, the wellhead pressure remained constant at $32.3 \mathrm{~m}(316 \mathrm{kPa})$. A continuous, wellpronounced wellhead pressure rise started on May 9 and continued until at least July 11. After termination of injection, the wellhead pressure was at $33.4 \mathrm{~m}(327 \mathrm{kPa})$, the highest recorded. This unusually high wellhead pressure rise is probably related to the injection into RRGI- 6 between March 25 and June 15, with the probable drawdown due to pumping RRGE-3 being masked by the larger buildup due to injection.

\section{USGS-3}

- Wellhead elevation-1486 m

- Well depth-434 m

- Open borehole-1426 to $1052 \mathrm{~m}$. 
Monitor well baseline data from USGS-3 are available since 1976 (Figure 27). The potentiometric head changes are irregular and do not follow a seasonal pattern. The long-term data indicate that the aquifer monitored by USGS-3 has a good hydraulic connection to the geothermal system and is strongly related to activity at RRGI-4. The distinctive wellhead pressure buildup, particularly the increase beginning May 28, 1978, are correlated with injection tests into RRGI-4 well. Sharp decreases in the potentiometric head in 1977 are associated with artesian flows of RRGI-4. Wellhead pressure data do not indicate a good hydraulic communication with the geothermal reservoir affected by RRGP-4, either before or after hydraulic fracturing in 1979. An examination of available data indicates that USGS-3 declines in response to withdrawals from RRGP-5. There was a slightly distinguishable wellhead pressure buildup during October and November 1981 which probably resulted due to injection. No withdrawals occurred from RRGP-5C during this period. The potentiometric head data indicate that this well is hydrologicallyisolated from seasonal potentiometric head changes occurring in the Shallow Aquifer. This well is believed to be monitoring potentiometric head responses in the Intermediate Aquifer, and probably the Geothermal Aquitard/Aquifer and the Metamorphic and Basement Geothermal Aquifer.

In 1982, the wellhead pressure declined only slightly (Figure 26). This slight decline is probably caused by withdrawals from RRGP-5C; or possibly another production well. Basically, the potentiometric heads in USGS-3 appear to have declined slightly in response to withdrawals during power plant operations in 1982.

\section{BLM Offset Well}

- Wellhead elevation-1500 m

- Well depth-123 m

- Open borehole-1480 to $1377 \mathrm{~m}$.

This well, which is located near the BLM well (Figure 1) exhibits a long-term potentiometric head response (Figure 28) somewhat similar to that of the USGS-3 well. The potentiometric head in this well increased in response to injection into RRGI-4 in 1978 as did USGS-3, MW-1, and -2. The poten- tiometric head declined in response to withdrawals from RRGE-3 in 1980 as did MW-1 and possibly $\mathrm{MW}-2$. The only responses to pumping and injection during power plant operations appear to have occurred in October and November 1981 and possibly in 1982 (Figures 26 and 28). The potentiometric head began to increase in February 1982, prior to injection for power plant operations. This increase may have resulted due to either withdrawals from RRGP-5, which coincidentally began in early February or from a natural response in the hydrologic system due to recharge and dischargerelated phenomena. The effects due to pumping and/or injection may be present, but are masked by the apparently unpredictable potentiometric head. Thus, the BLM offset well potentiometric head has responded to injection into RRGI-4, production from RRGE-3, and probably production/injection in 1981 and 1982. These potentiometric head changes are believed to be indicative of those occurring in the Intermediate Aquifer and possibly the Geothermal Aquitard/Aquifer as well.

\section{Geochemistry}

Because of the lack of monitor wells completed entirely within the Intermediate Aquifer, the implied geochemical data for the groundwater in this aquifer may have considerable errors associated with them. Figure 17 depicts the vertical distribution of temperatures. Except where the faults permit geothermal fluid originating in the Metamorphic and Basement Geothermal Aquifer to leak into the Intermediate Aquifer, the temperature in the Intermediate Aquifer along Cross Section AA' is probably relatively uniform. This is due, in part, to the thermally-induced convective flow system. The temperature reversal for RRGI-7 (Figure 20) is $0.6^{\circ} \mathrm{C}$. Presumably, the hot geothermal fluid leaks up faults breaching the underlying Geothermal Aquitard/Aquifer, rises to the top of the aquifer because the density is less than that of the "native" fluid, and then migrates laterally. The hydrologic continuity of the faults in the Intermediate Aquifer is undoubtably such that considerable leakage occurs from the fault zone into the Intermediate Aquifer. Mixing of the geothermal fluid leaking up faults with "native" fluid in the Intermediate Aquifer is thus possible. The water quality and temperature data may vary over short vertical distances near a geothermal plume as a result of convective flow. Areal differences in temperature probably exist (Figure 20) 


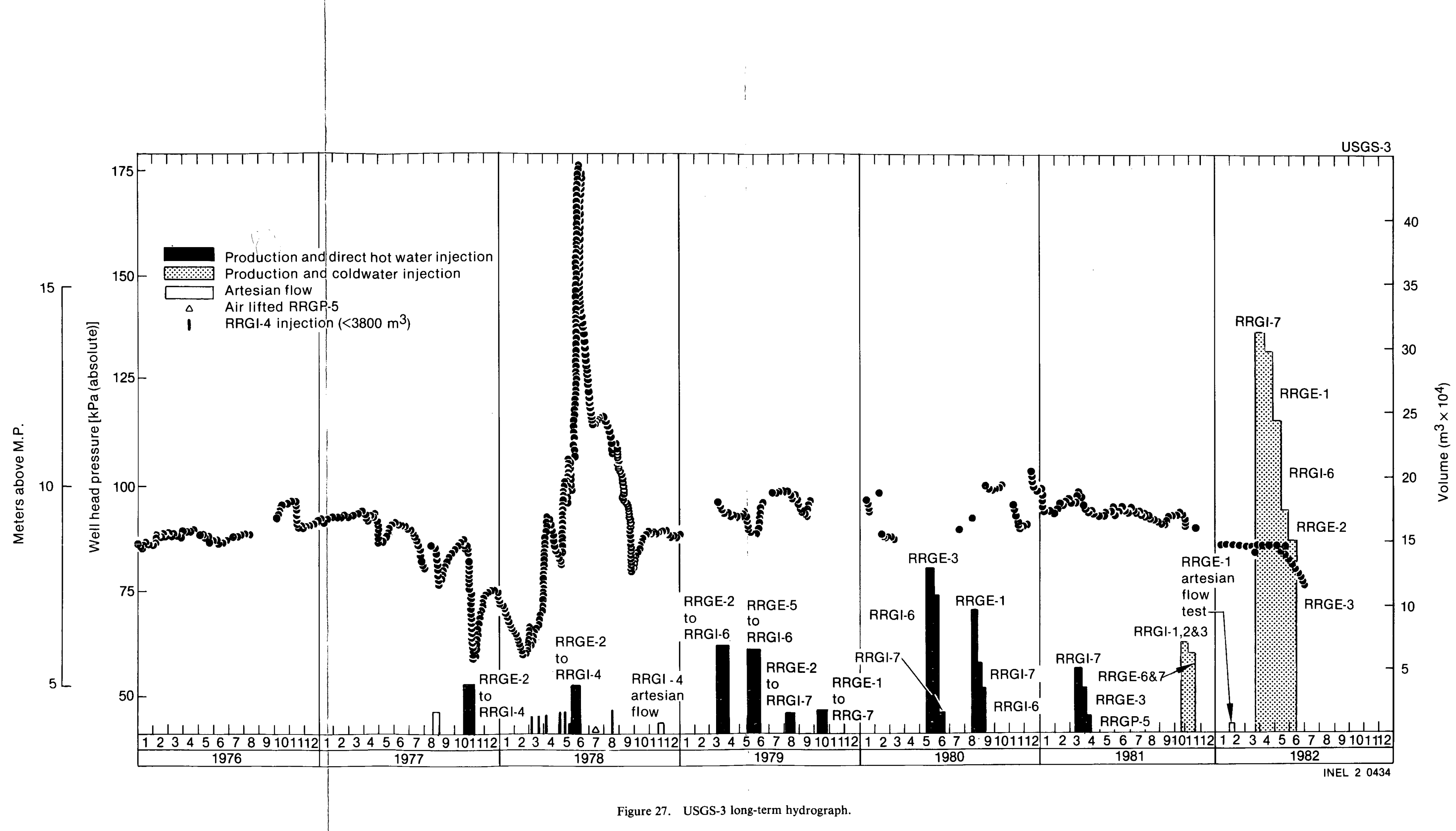




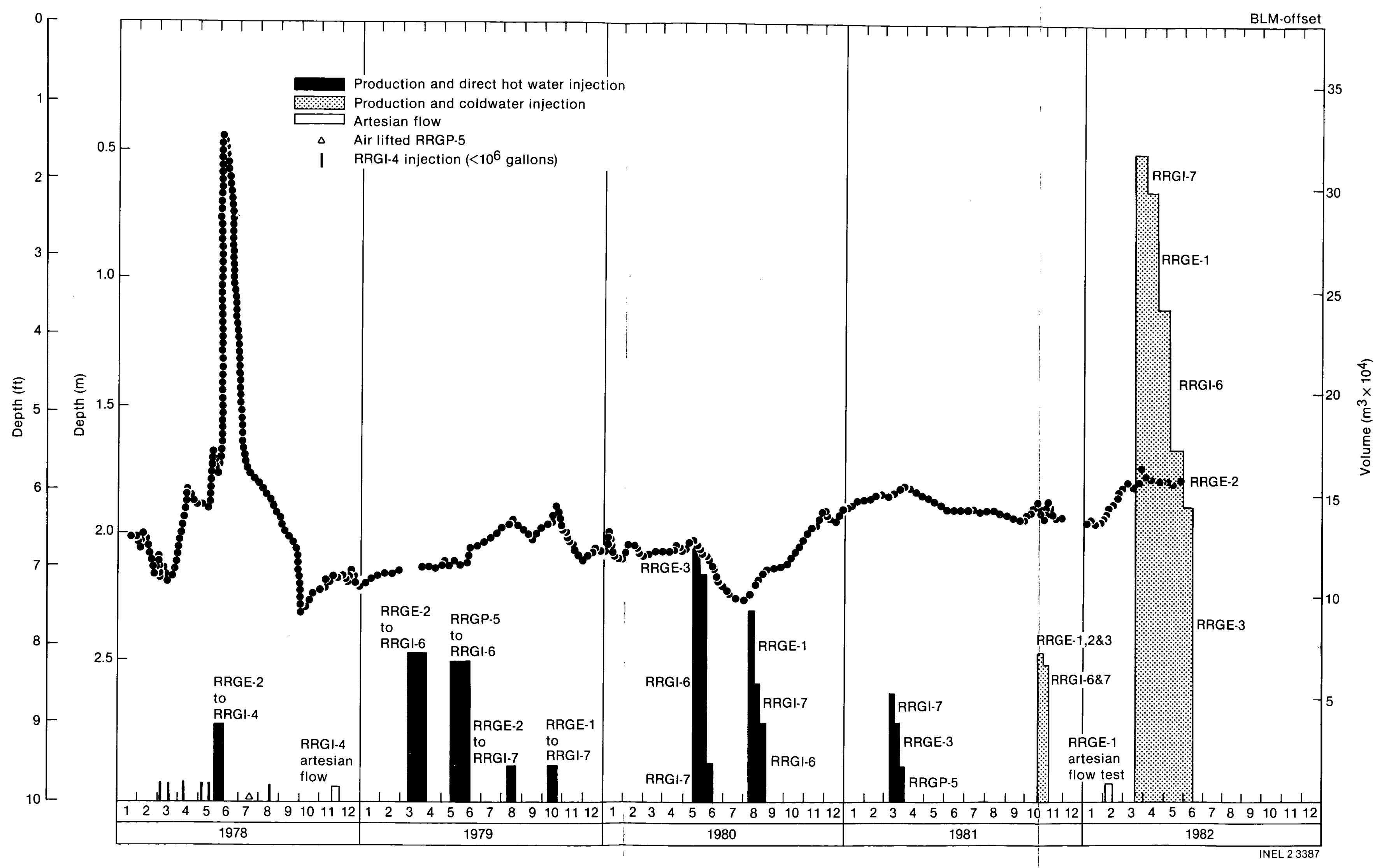

Figure 28. BLM offset long-term hydrograph. 
but suitable temperature logs for all the production and injection wells are not available. This thermally-induced convective flow system which has developed within the Intermediate Aquifer has contributed, in part, to a reduction in lateral thermal gradients.

The distribution of the specific conductance in Cross Section AA' is indicated in Figure 19. The contours for the specific conductance imply the lateral migration of a mixture of geothermal fluid which leaked from the Metamorphic and Basement Geothermal Aquifer and more dense fluid from near the bottom of the Intermediate Aquifer. The mixing would occur primarily near influxes of geothermal fluid. The ground-water flow component parallel to Cross Section $\mathrm{AA}^{\prime}$ is presumed to be directed from the BLM well towards MW-6, with a small flow reversal at the top of the Intermediate Aquifer near the fault penetrated by $M W-2$. The gross rate of groundwater flow in the Intermediate Aquifer is pre- sumed to be much greater between the BLM well and MW-2 than between MW-2 and -6. The concentration of discharge to the Shallow Aquifer near MW-2 is believed to account for the differences in the rate of ground-water flow in the Intermediate Aquifer. As a result, the isocons are more closely spaced between MW-2 and -6 than between the BLM well and MW-2.

The groundwater being discharged into the Intermediate Aquifer from the Geothermal Aquitard/Aquifer has a higher specific conductance near RRGI-6 than near RRGP-5. The apparent fault-flow-dominated discharge into the Intermediate Aquifer between RRGP-5 and MW-2 is more conducive to a large influx of relatively low specific conductance fluids than the apparent flow-through-porous-media type dominated flow from the Geothermal Aquitard/ Aquifer near RRGI-6. A closer spacing of the isocons thus results between $M W-2$ and -6 than between the BLM well and MW-2. 


\section{GEOTHERMAL AQUITARD/AQUIFER}

\section{Hydrology}

The Geothermal Aquitard/Aquifer is a fractured and consolidated sedimentary unit that behaves as an aquitard in retarding the vertical migration of geothermal water, while behaving as a geothermal aquifer in the faults near the Metamorphic and Basement Geothermal Aquifer. In addition, this hydrologic unit functions as a flow-through-porous-media type of aquifer for injection (RRGI-7 and, to a lesser degree RRGI-6). This unit contains considerable tuff $19,20,21$ which serves as an aquitard or possibly an aquifuge to the vertical movement of water via porous media flow. Presumably, less tuffaceous interbeds of silt and sandstone function as aquifers for the horizontal transmission of water; this is especially evident in RRGI-7. The vertical interconnection of these aquifers is not known, but is probably poor except where intersected by faults which can either convey water from, or discharge water into, an aquifer. The listric faults serve as vertical conduits conveying geothermal fluids upward from the Metamorphic and Basement Geothermal Aquifer and from the lower portions of the listric faults near the Metamorphic and Basement Geothermal Aquifer-Geothermal Aquitard/Aquifer contact. Previously, the faults near the base of the sediments were assumed to be the major geothermal production aquifer in the Raft River KGRA. ${ }^{7}$

The faults (Figure 4) along the flanks of the Jim Sage Mountains and the Raft River Mountains presumably intersect in the Raft River flood plain near MW-2. Thus, a major breach probably occurs through the Geothermal Aquitard/Aquifer in this area, which leaks geothermal water into the Intermediate Aquifer and then into the Shallow Aquifer. To a lesser degree, the Geothermal Aquitard/Aquifer is probably also breached along the Bridge and Horse Well Faults (Figure 2). For the majority of the faults, however, leakage losses are somewhat restricted, as evidenced by the much greater potentiometric heads in the Metamporphic and Basement Geothermal Aquifer production wells. Thus, the Geothermal Aquitard/Aquifer serves as a source of geothermal water for production wells, a sink for injection wells, and an aquitard, reducing the vertical leakage losses from the injection aquifers and the Metamorphic and Basement Geothermal Aquifer.
The orientation of the faults and their permeable nature can be expected to result in an anisotropic and heterogeneous spatial distribution of permeability. The permeability in the fault planes in general would be expected to be much greater than in the host rock. Within the fault planes, the permeability and transmissivity are not everywhere uniform and vary from being an aquitard in fault planes, presumably penetrating the open wellbore of RRGP-4 prior to stimulation, to open fractures, presumably in RRGE-1 and $\mathbf{- 2}$. The permeability thus varies over a wide range of values within the fault plane depending on such variables as fracture zone widths, fracture spacings, secondary precipitation of calcite and silica, etc. The flow in the fault planes is probably somewhat channelized spatially which likely contributes to the nonporous-media-type drawdown characteristics $^{22}$ of production wells RRGE-1 and -2 . Because the transmissivity in the fault planes is generally greater than that of the host rock, as evidenced during drilling, the Geothermal Aquitard/Aquifer has an anisotropic and heterogeneous spatial distribution of permeability.

The areally-varying anisotropic and heterogeneous permeability will affect the ground-water flow system in the Geothermal Aquitard/Aquifer. In the Horse Well and Bridge Fault area (Figures 2, 3, and 4) the transmissivity is presumably greater in the north-south direction than east-west. Similarly, the transmissivity near RRGE-3 is probably greater in the northwestsoutheast direction than northeast-southwest. The lack of observation wells in the Geothermal Aquitard/Aquifer and test data do not permit confirmation of the assumed anisotropies. Since the Horse Well and Bridge Faults are approximately parallel to the equipotential contours [addressed in Metamorphic and Basement Aquifer section (Figure 30)] ground-water flow directions may be almost parallel to the equipotential contours as a result of the anisotropy and heterogeneity in permeability. This can result in a complex flow system. However, for the faults near RRGE-3, the hypothesized contours on the equipotential surface are almost perpendicular to the faults. This condition would tend to maximize flow rates in the faults and reduce the hydraulic gradient. The reduced hydraulic gradient would result in a deterioration in water quality in the unfractured host rock due to reduced flow rates. 
This may account in part for the poor quality water produced by RRGE-3. The presence of highly transmissive faults in the Geothermal Aquitard/Aquifer complicates both the natural ground-water flow system and that which results due to withdrawals from the production wells.

There are no monitor wells completed in the Geothermal Aquitard/Aquifer.

\section{Geochemistry}

The isotherms in the Geothermal Aquitard/ Aquifer are relatively simple in Cross Section AA' (Figure 17). In this hydrologic unit, the isotherms are at a greater depth near production wells RRGE-1, -2, and RRGP-5 than at RRGE-3 and RRGI-6. The probable decreasing ground-water mass flow rates in the Metamorphic and Basement Geothermal Aquifer, and the lower portion of the Geothermal Aquitard/Aquifer from the BLM well area towards $\mathrm{MW}-6$, due to the discharge in the vicinity of the flood plain, would favor the development of isotherms at a gradually decreasing depth in a downstream direction. The injection wells and RRGE-3 penetrate higher temperature fluids at shallower depths in the Geothermal Aquitard/Aquifer than the other production wells. The thermal data collected with borehole geophysical logs indicate higher temperatures at a shallower depth in the vicinity of RRGE-3 and the injection wells than near the production wells within the Geothermal Aquitard/Aquifer.
Wellhead temperature data (Figure 29) during production also indicate an increasing temperature from the BLM well towards RRGE-3. The wellhead temperatures when pumping at RRGE-1, $-2,-3$, and RRGP-5 are 135.8, 136.2, 140.5, and $129.5^{\circ} \mathrm{C}$, respectively, using calibrated mercury thermometers. During production, geothermal fluid can be withdrawn from any aquifer penetrated by the open borehole because of the large wellbore drawdown. Since only slight cooling occurs while the fluid is migrating up the wellbore, the wellhead temperatures during production provide reasonable estimates of the temperature of geothermal fluid in the uncased section of the borehole. Isotherms of these wellhead temperature data (Figure 29) trend NE-SW suggesting a possible recharge zone to the NW for the geothermal fluid.

The isocons in Figure 19 have been constructed to indicate increasing specific conductance with decreasing depth in the Geothermal Aquitard/ Aquifer as would be expected to occur in a discharge area. The isocons indicate a higher gradient between MW- 2 and -6 than between the BLM well and MW-2. This can be interpreted as indicating decreasing mass flow rates and longer fluid residence time between $M W-2$ and -6 than between the BLM well and MW-2. In conclusion, the isocons for specific conductance in the Geothermal Aquitard/Aquifer suggest a recharge area to the NNW or NW from the Raft River production wells with upward migrating geothermal fluid and deteriorating water quality in the Geothermal Aquitard/Aquifer in the vicinity of the Raft River KGRA. 


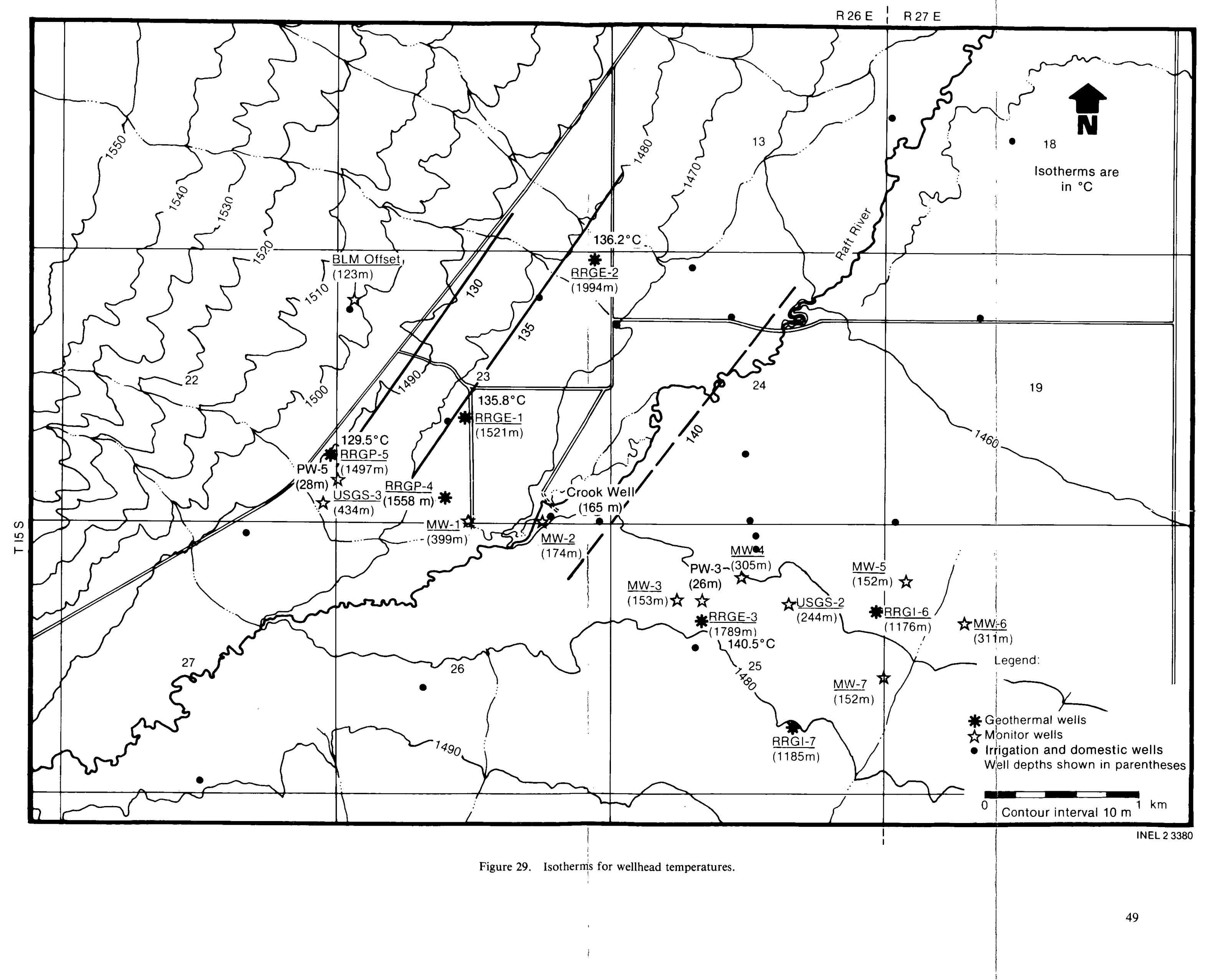




\section{METAMORPHIC AND BASEMENT GEOTHERMAL AQUIFER}

\section{Hydrology}

The Metamorphic and Basement Geothermal Aquifer consists of faulted metamorphic rocks overlying an adamellite basement. ${ }^{23}$ In the Raft River production wells, the Metamorphic and Basement Geothermal Aquifer consists of the Quartzite of Yost, the Schist of the Upper Narrows, the Elba Quartzite, the Older Schist, and an adamellite which is generally gneissic. ${ }^{19-21,23-28}$ Two of these metamorphic units are missing in some of the wells, possibly as a result of movement on low-angle faults.

Fracture-flow is responsible for high well yields from the aquifer. All of the production wells, with the possible exception of RRGE-3, obtain fluids from the fractured section in the Metamorphic and Basement Geothermal Aquifer. The production in RRGP-5 is solely from the metasediments. During well stimulation by fracture treatment, $195,000 \mathrm{~kg}$ of sand were injected. ${ }^{29}$ The authors suspect the majority of this sand entered the voids in the natural fault system(s) which were partially grouted both during well construction and prior to stimulation. In RRGE-2, 30\% of the flow originates near the contact between the metamorphics and the adamellite at $\sim 1524 \mathrm{~m}$, while $10 \%$ was obtained at a depth of $\sim 1829 \mathrm{~m}$ in the adamellite. ${ }^{30}$ In RRGE-1, based on a reversal in the temperature logs, some production is obtained from within the metasediments. Geochemical logging $^{31}$ for RRGP-4A indicate limited production was obtained from the metamorphics and adamellite. Data are not available for delineation of the production zone(s) for RRGE-3. Thus, the field evidence indicates a significant portion of the production originates in the Metamorphic and Basement Geothermal Aquifer.

The spatial configuration of the joints and fault planes in the Metamorphic and Basement Geothermal Aquifer are not completely understood. It can be expected that the fault planes would be near-horizontal, with possibly steeply-dipping fractures or faults overlying the low-angle faults, between faults, and within the low-angle fault zones. Both the low-angle fault zones and the steeply-dipping faults and fractures can be productive. However, cores 24 indicate that fractures and vugs contain quartz and calcite crystals that have precipitated from solution. As a result, some fractured zones may be nonproductive due to quartz and calcite deposition. Since these lowangle faults are structural zones of weakness, they may be responsible, in part, for the overlying listric faults. High hydrostatic pressures in the low-angle fault zones, due to processes such as low natural discharge in the Raft River flood plain prior to faulting, could significantly reduce the horizontal maximum possible intergranular shear stress at the base of the sedimentary sequence overlying the Metamorphic and Basement Geothermal Aquifer. Since the surface of the Metamorphic and Basement Geothermal Aquifer has an apparent slope to the SE, conditions for mass glide-block movements, in an easterly direction from the Jim Sage Mountains are favorable and have been mapped. 5 Similar conditions are presumed to exist along the north-facing slope of the Raft River Mountains. In addition, slickensided surfaces were observed on the surface of the metamorphic sequence in a RRGE-1 core. ${ }^{24}$ With the development of the listric faults, vertical open fractures near the base of the sediments ${ }^{7}$ serve as an additional aquifer. The lateral transport of water from the Jim Sage Mountains, via the Metamorphic and Basement Geothermal Aquifer to the Raft River flood plain, with subsequent upward leakage to the basal section of the listric faults, is believed to be the basis of the geothermal flow system.

The hydraulic and thermal relationships between RRGP-5 and RRGE-1 provide some insight into the Metamorphic and Basement Geothermal Aquifer flow system. The wellhead temperature for RRGP-5 is the lowest of all the production wells $\left(129.5^{\circ} \mathrm{C}\right)$, with the overlying rock being hotter than the production zone as indicated by borehold temperature logs and wellhead temperature data during production. This well (RRGP-5A) was also the most productive geothermal well prior to setting cement plugs in the open borehole during construction. The high productivity and a thermal gradient directed from the rock toward the production zone can be expected in a conduit type flow system conveying cold water at a relatively high velocity from the recharge area to the discharge area. Mapped (Figure 4) and unmapped faults trending E-W or NW-SE and extending from the surface to the Metamorphic and Basement Geothermal Aquifer 
could also be contributing to the flow system conveying water from the Jim Sage Mountains to the Raft River KGRA. A temperature log in RRGE-1 also reveals a production zone in the Metamorphic and Basement Geothermal Aquifer with a lower temperature than the overlying and underlying rocks. The excellent hydraulic connection observed between RRGP-5 and RRGE-1 during pump testing is probably via this low temperature zone in the Metamorphic and Basement Geothermal Aquifer. The thermal gradient directed from the surrounding rock towards the producing zone in the Metamorphic and Basement Geothermal Aquifer in RRGE-1 and RRGP-5, combined with the lack of productivity of RRGP-4, can be interpreted as indicating that the production zones in the Metamorphic and Basement Geothermal Aquifer are not areally continuous. Conductive heat transfer to the overyling rock mass can occur in the areas where productive zones are lacking, thus resulting in the rock mass overlying the producing zones having a higher temperature than the production zones. In addition, if the Raft River KGRA were downgradient from an area such as The Narrows, where the fluid temperature was greater than that in the Raft River KGRA, the temperature of the fluid in the most productive zones would be expected to be greater than that in the surrounding rocks. The lower most productive zone would not be expected to be the coldest. In conclusion, the data are believed to support the hypothesis that the Metamorphic and Basement Geothermal Aquifer is the principal source or local origin of the geothermal fluid in the Raft River KGRA.

The adamellite underlying the metamorphic rocks has previously been reported to be of low permeability and to "not contain a significant part of the geothermal resource."7 These geothermal models 4,7 were based on deep circulation of meteoric water from the Albion, Goose Creek, and Raft River Mountains along major faults, with upward migration along The Narrows structure to the overlying sedimentary basin fill. The existence of The Narrows structure is based on limited geologic and geophysical data which suggest a basement shear passes through The Narrows and near RRGE-1.5 The authors believe that the field evidence, based on thermal, hydrologic, and water quality data, support the hypothesis that the Metamorphic and Basement Geothermal Aquifer is the primary aquifer for conveying geothermal fluid to the Raft River KGRA. With this hypothesized flow system, the elusive Narrows structure is not required.

Potentiometric surface data for the production wells suggest that the ground-water flow in the production zone(s) is generally from the NW to SE (Figure 30). The potentiometric surface is that calculated for an aquifer at an elevation of $78 \mathrm{~m}$ (elevation of temperature reversal in RRGE-1) assuming a reservoir temperature of $137.8^{\circ} \mathrm{C}$. Since these estimates for the potentiometric surface are obtained from wellhead pressure data, significant errors can be expected. Since the potentiometric surface decreases with decreasing depth, the potentiometric surface depicted in Figure 30 is lower than that in the Metamorphic and Basement Geothermal Aquifer, but greater than that in the overlying listric faults of the Geothermal Aquitard/Aquifer. The difference in the potentiometric surfaces in the Metamorphic and Basement Geothermal Aquifer and the Geothermal Aquitard/Aquifer is probably on the order of a few meters. However, even with these errors, the large difference $(\sim 22 \mathrm{~m})$ in potentiometric surface between RRGE-3 and the other production wells still strongly suggests the ground-water flow is from a recharge area located to the NW.

\section{Geochemistry}

The wellhead water quality data for RRGE-1 and -2 , and possibly RRGE-3 and RRGP-5, are dependent on the preceeding discharge history of the well. When RRGE-1 is either shutin, or discharging at a very low rate of $\sim 2.87 \mathrm{~L} / \mathrm{s}$ or less, geothermal fluid from the lowest aquifer in the open borehole enters the wellbore and flows upward (downgradient) and into an overlying aquifer penetrated by the open borehole. The native fluids in the overlying aquifer are forced to migrate away from the wellbore and are replaced by fluids originating in the deepest aquifer. This upward flow of fluid results because of the decreasing potentiometric head with decreasing depth as is typical in a ground-water discharge area. Thus, as long as the wellhead discharge is sufficiently low to maintain a hydraulic gradient directed away from the wellbore in all aquifers except the deepest, the water quality in the wellbore will essentially become that in the deepest aquifer. In the case for RRGE-1 and -2, this is the 


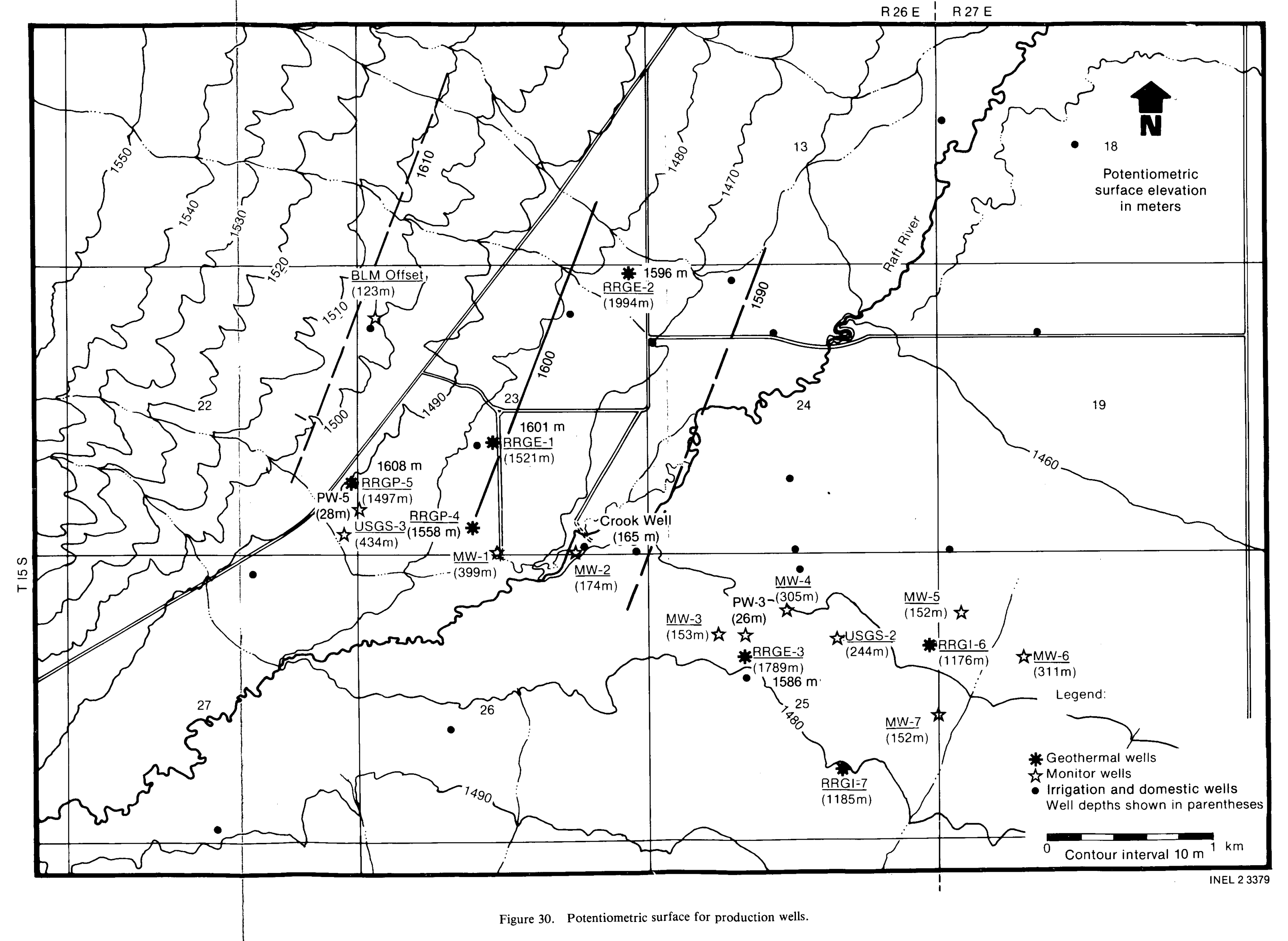


Metamorphic and Basement Geothermal Aquifer. Since the specific conductance, chlorides, and most other ions in solution generally increase in concentration downgradient in a ground-water flow system, ${ }^{32}$ the highest quality geothermal fluid will occur in the deepest aquifer which has the highest potentiometric head. Thus, the wellbore will contain the highest quality fluid when the wellhead is discharging at low rates. This is the case for RRGE-1 and -2 (Table 3). The specific conductances of 2000 and $2160 \mu \mathrm{S}$ and chloride concentrations of $17.569 \mathrm{meq} / \mathrm{L}(623 \mathrm{mg} / \mathrm{L})$ and $16.694 \mathrm{meq} / \mathrm{L}(592 \mathrm{mg} / \mathrm{L})$ for RRGE- 1 and -2 are the lowest for all geothermal, monitor and private wells listed in Table 3, with the possible exception of USGS- 2 which has a very shallow casing depth. Thus, the wellhead water quality data indicate that upward flow occurs within the wellbore of RRGE-1 and -2 when wellhead discharge is $<2.87 \mathrm{~L} / \mathrm{s}$, which results in low specific conductance and low chloride concentrations.

With these hydrologic conditions in the wellbore, temporal changes in water quality following initiation of high drawdown-induced wellhead discharge rates can be expected. When the well is produced at a wellhead discharge rate that is sufficient to induce fluid flow back into the wellbore in the shallowest aquifer penetrated by the uncased borehole, the fluid which originated in the deepest aquifer flows back into the wellbore. The volume of fluid in the shallowest aquifer which originated in the lowest aquifer, depends on the hydrologic characteristics and conditions in the aquifers involved, as well as the elapsed time between periods of large borehole drawdowns, in addition to the duration of the preceeding drawdown period. Under these conditions, the wellhead water quality during pumping depends on the preceding wellhead discharge history. Since this history is usually different for each pumping period, a unique temporal wellhead water quality variation cannot be expected. With these hydrologic conditions, significant variations in wellhead water quality can be expected throughout the history of a well.

Significant variations in water quality have been observed in RRGE-1 and -2 after pumping. At the end of $\sim 70$ days of pumping for power plant operations in 1982, the specific conductance in RRGE- 1 and -2 increased to 3000 and $2500 \mu \mathrm{S}$, respectively. These are respective increases of 50 and $16 \%$ over the analyses in Table 3 . Similarly, the chloride concentrations for RRGE- 1 and -2 were $30.46 \mathrm{meq} / \mathrm{L}(1080 \mathrm{mg} / \mathrm{L})$ and $23.60 \mathrm{meq} / \mathrm{L}$ $(837 \mathrm{mg} / \mathrm{L})$; these are increases of 73 and $42 \%$, respectively. These large temporal variations in water quality are expected in the hypothesized geothermal flow system at Raft River.

Isotherms for Cross Section $\mathrm{AA}^{\prime}$ are indicated in Figure 17. Suppressed temperatures are presumed to result near the faults where flow velocities are highest (such as at RRGP-5). The $140^{\circ} \mathrm{C}$ isotherm has been constructed to illustrate this type of flow. In general, the isotherms in the Metamorphic and Basement Geothermal Aquifer probably tend to be less horizontally-inclined than those in the Geothermal Aquitard/Aquifer.

Isocons for the fluid specific conductance are indicated in Figure 19. The isocons in the Metamorphic and Basement Geothermal Aquifer have been constructed to indicate the higher quality fluids in the Metamorphic and Basement Aquifer relative to those in the overlying Geothermal Aquitard/Aquifer. This is the typical situation in a discharge area. In general, except for the Shallow Aquifer, the specific conductance is at a minimum in the Metamorphic and Basement Geothermal Aquifer.

Wellhead temperature and specific conductance data indicate a zone, at depth, which is producing water of a lower temperature and lower specific conductance than overlying producing zones. Wellhead temperature data at RRGE-1 indicate a short duration increase in temperature of $\left(\sim 0.3^{\circ} \mathrm{C}\right)$ after pumping a sufficient volume of fluid to sweep $\sim 1400 \mathrm{~m}$ of fluid from the wellbore. This corresponds closely with the $1417 \mathrm{~m}$ depth in the metamorphics where a temperature $\log$ indicated a temperature reversal. ${ }^{33}$ The elevated wellhead temperature results because of heating of the wellbore fluid by the wall rock when the well is shutin. When the well is pumped, this slug of warmer fluid is displaced out of the wellbore by the cooler fluid produced by the aquifer underlying the borehole interval with an elevated temperature. This is essentially the same situation as at RRGP-5B prior to well stimulation $^{34}$ and at RRGP-5C Thus, the wellhead temperature data at both RRGE-1 and RRGP-5B indicate a temperature reversal in the wellbore at depth. 
Wellhead data indicate a rapid temporal increase in specific conductance at the time the temperature peaks following the resumption of pumping as indicated in the preceding paragraph. On 10/28/81, while pumping at $68.76 \mathrm{~L} / \mathrm{s}$ at RRGE-1, the specific conductance increased from $2800 \mu \mathrm{S}$ after $32 \mathrm{~min}$ of pumping, to a steady state value of $3020 \mu \mathrm{S}$ after $1 \mathrm{~h}$ of pumping. This increasing specific conductance coincided with a declining wellhead temperature. Thus, the specific conductance data indicate a deterioration in water quality after the passage at the wellhead of the thermal peak. This is interpreted as indicating that the aquifer producing the cooler water at a depth of $1417 \mathrm{~m}$ in the metasediments, as indicated on borehole temperature logs, also produces fluids of a lower specific conductance than those in the overlying aquifers. The lower temperatures and higher quality water in the deepest production zone in RRGE-1 suggest that the well is located in a ground-water discharge area, the source of which is located in the Metamorphic and Basement Geothermal Aquifer.

Significant areal variations also occur in the specific conductances and chloride ion concentrations for the production wells when they are pro- ducing fluid derived solely from the Metamorphic and Basement Geothermal Aquifer. The data listed in Table 3 for RRGE-1, -2, -3 , and RRGP-5 are generally for the highest quality fluid produced by the wells for which analyses are available. Deliberate flow control to obtain water from the Metamorphic and Basement Geothermal Aquifer for water quality analysis can be -expected, in general, to decrease the concentrations reported in Table 3 . However, even with these questionable data, it is believed that some generalizations can be made. Figure 31 is a contour map for the specific conductances $(\mu \mathrm{S})$ for production well fluid. Figure 32 is a contour map for the chloride ion concentrations (meq/L) for the production well fluid. The specific conductances and chloride ion concentrations both increase from the NW towards the SE, implying ground-water flow from the NW to the SE. The isotherms, (Figure 29), and the potentiometric surface, (Figure 30), also suggest ground-water flow from the NW to the SE. Although based on water samples of questionable validity, the specific conductances and chloride ion concentrations suggest a ground-water flow direction from the NW to the SE. 


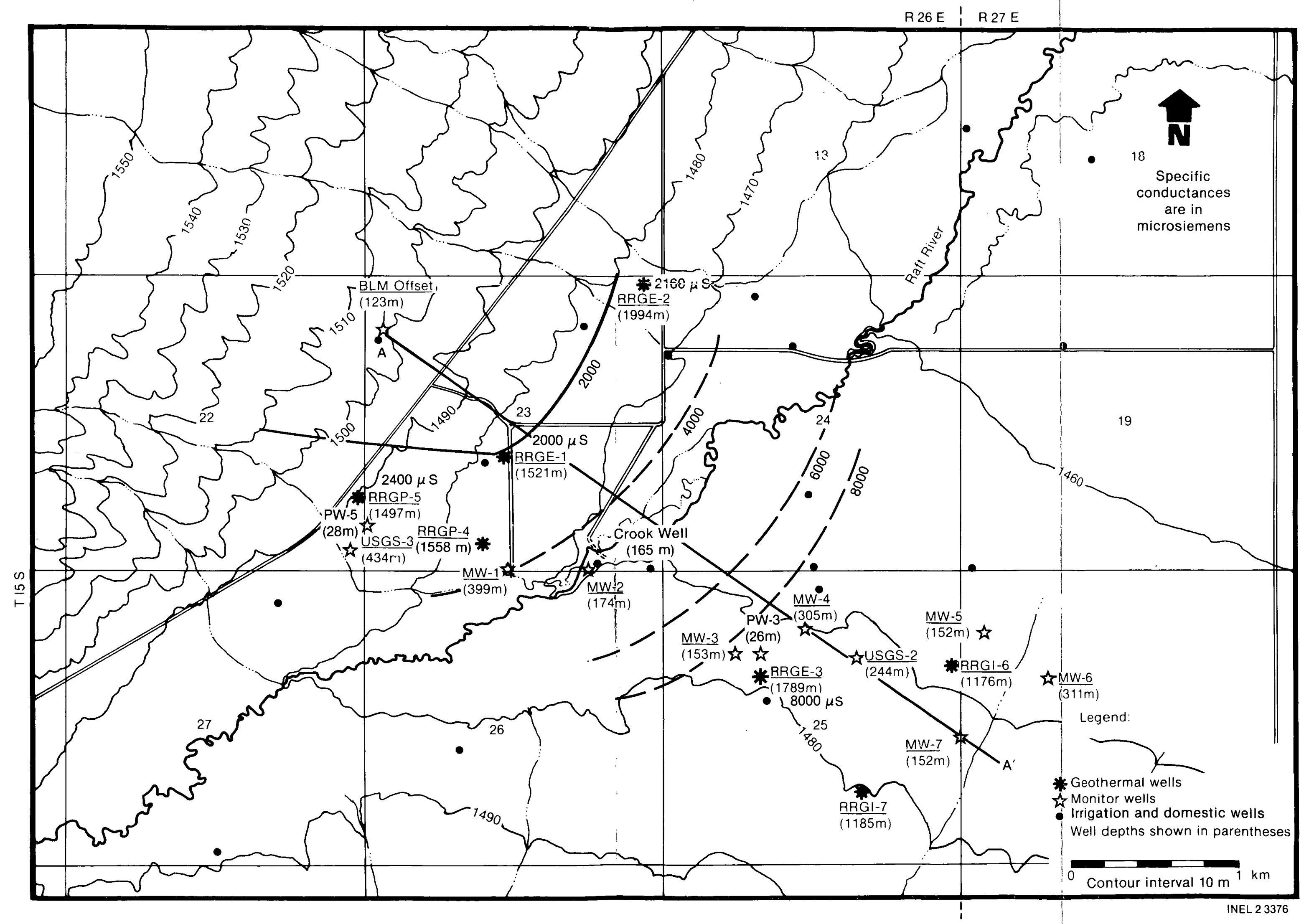

Figure 31. Specific conductances for production wells. 


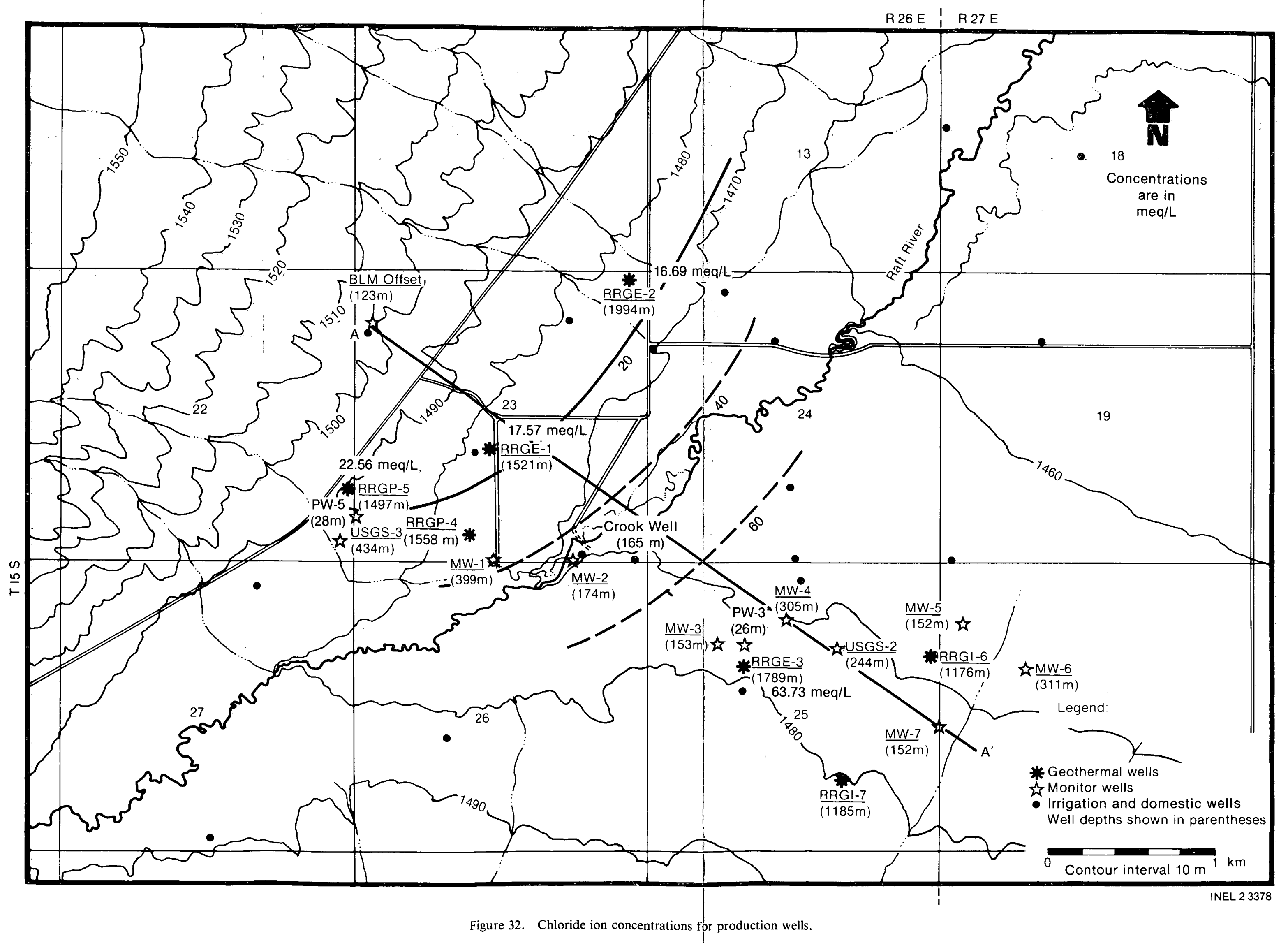




\section{ALTERNATE MODELS}

With the few control points in the form of deep production wells, and the complexities added by fracture flow in numerous fault zones, combined with few monitor wells in the Intermediate Aquifer and deeper, alternate hydrogeologic and geochemical models can be readily conceived. For example, the ground-water flow direction in the Metamorphic and Basement Geothermal Aquifer and/or the Intermediate Aquifer to the southeast of the Raft River flood plain may be directed towards the northwest i.e., the discharge area in the flood plain rather than towards the southeast as hypothesized in this report. Furthermore, the discharge areas for the Metamorphic and Basement Geothermal Aquifer may not be under the Raft River flood plain, but nearer the Bridge Fault passing near or through RRGE-1. This may account for the poor quality water in MW-1. Additional data to be collected in tests on RRGP5C may provide additional insight into the geothermal flow system at Raft River. 


\section{CONCLUSIONS}

1. Significant leakage of geothermal fluid into the Shallow Aquifer occurs in the vicinity of MW-2, possibly at the intersection of multiple fault systems paralleling both the Jim Sage Mountains and the Raft River Mountains.

2. Pit Well $-3,-5, \mathrm{MW}-3,-5,-6,-7$, and USGS-2 have potentiometric head trends indicative of those in the Shallow Aquifer.

3. The Lower Aquitard is the primary hydrogeologic unit limiting leakage from the Intermediate Aquifer into the Shallow Aquifer. The Lower Aquitard appears to be breached by faults which localize leakage losses from the geothermal system.

4. The Intermediate Aquifer is an areallyextensive sedimentary aquifer which has thermally-induced convective flow. The potentiometric heads in this aquifer are monitored to some extent via permeable faults or fractured zones in MW-1, -2, -4 , BLM offset and the BLM well. The USGS-3 well is the only monitor well with at least a portion of the open borehole penetrating this aquifer.

5. Injection into RRGI-6 results in pressure buildups in MW-1, $-2,-4$ and possibly the BLM offset, as a result of their probable completion in or near faults hydraulically connected to the Intermediate Aquifer. Potentiometric head declines due to injection are observed in MW-4, $-5,-6,-7$, USGS-2, and possibly MW-3 and PW-3. This falloff due to injection presumably results due to deformation of the Upper Aquitard and Shallow Aquifer due to pressure in the Intermediate Aquifer.
6. Injection into RRGI-7 results in no clearly-defined buildup responses in wells other than RRGI-6. The receiving aquifers in RRGI-7 are located solely within the upper portion of the Geothermal Aquitard/Aquifer which effectively isolates the pressure buildup during injection from the Intermediate Aquifer.

7. Hydrologically, the production and injection well area at the Raft River KGRA is a ground-water discharge area with decreasing potentiometric heads at decreasing depths.

8. Potentiometric head, wellhead temperature, specific conductance, and chloride ion concentration data for the production wells are interpreted as indicating that the general ground-water flow direction in the Metamorphic and Basement Geothermal Aquifer and the lower portion of the Geothermal Aquitard/Aquifer is from the NW towards the SE.

9. Significant temporal degradation in water quality results in RRGE-1, -2 , and possibly RRGP-5B, as a result of pumping, due to the upward-directed hydraulic gradient during shutin conditions and the multiaquifer well completion for RRGE-1 and $\mathbf{- 2}$.

10. Potentiometric head declines due to RRGE-3 pumpage have been observed in MW-1, and BLM offset. Withdrawals from RRGP-5B may have resulted in a potentiometric head decline in USGS-3. Pumpage from RRGP-5 has resulted in a potentiometric head buildup in PW-5. 


\section{REFERENCES}

1. W. D. Nichols, Simulation Analysis of the Unconfined Aquifer, Raft River Geothermal Area IdahoUtah, U.S. Geological Survey Water-Supply Paper 2060, 1979.

2. S. G. Spencer and D. M. Callan, An Analysis of the Response of the Raft River Monitor Wells to the 1979 Injection Tests, EGG-2027, 1980.

3. M. R. Dolenc et al., Raft River Geoscience Case Study, EGG-2125, 1981.

4. P. L. Williams et al., "Geology and Geophysics of the Southern Raft River Valley Geothermal Area, Idaho, USA," Proceedings of the Second U. N. Symposium on the Development and Use of Geothermal Resources, 1976, pp. 1273-82.

5. D. R. Mabey et al., "Reconnaissance Geophysical Studies of the Geothermal System in Southern Raft River Valley, Idaho," Geophysics 43, 7, 1978, pp. 1470-1484.

6. H. D. Ackerman, "Seismic Refraction Study of the Raft River Geothermal Area," Geophysics, 44, 1979, pp. 216-225.

7. H. R. Covington, "Subsurface Geology of the Raft River Geothermal Area, Idaho," Geothermal Resources Council Transactions, 4, September 1980.

8. J. A. Tullis and M. R. Dolenc, "Geoscience Interpretations of the Raft River Resource," Geothermal Resources Council Bulletin, February 1982, pp. 6-9.

9. A. L. Anderson, "Geology and Mineral Resources of Eastern Cassia County, Idaho," Idaho Bureau of Mines and Geology Bulletin, 14, 1931.

10. D. M. Miller, Structural Geology of the Northern Albion Mountains South-Central Idaho, GSA Memoir 153, 1980.

11. D. E. French, Geology and Mineralization of the Southeastern Part of the Black Pine Mountains, Cassia County, Idaho, M.S. Thesis, Utah State University, 1975.

12. P. L. Williams et al., Preliminary Geologic Map of the Southern Raft River Area, Cassia County, Idaho, United States Geological Survey Open-File Report, 1974.

13. R. R. Compton, Geologic Map of the Park Valley Quadrangle, Box Elder County, Utah and Cassia County, Idaho, United States Geological Survey Miscellaneous Geologic Inventory Map I-873, 1975.

14. R. R. Compton et al., "Oliogocene and Miocene Metamorphism, Folding and Low-Angle Faulting in Northwest Utah," Geological Society of America Bulletin, 88, 1977, pp. 1237-1250.

15. R. R. Compton, Geologic Map of the Yost Quadrangle, Box Elder County, Utah and Cassia County, Idaho, United States Geological Survey Miscellaneous Geologic Inventory Map I-672, 1972.

16. Rocky Mountain Geo-Engineering Company, Drillers Log RRGI-6, April 29, 1978.

17. H. H. Shoopman, Completion Report, Raft River Geothermal Exploratory Hole No. 3, June 1977, Reynolds Electrical and Engineering Company, Inc., Las Vegas, Nevada, IDO-10069 (NUO-410-40).

18. W. L. Niemi and L. B. Nelson, "Irrigation Testing at RRGI-4, Raft River Idaho," Proceedings of the Second Invitational Well Testing Symposium, Lawrence Berkeley Laboratory, October 24-27, 1978. 
19. H. R. Covington, Deep Drilling Data, Raft River Geothermal Area, Idaho-Raft River Geothermal Exploration Well No. 5, United States Geological Survey Open-File Report 79-283, 1979a.

20. H. R. Covington, Deep Drilling Data, Raft River Geothermal Area, Idaho-Raft River Geothermal Production Well No. 4, United States Geological Survey Open-File Report 79-662, $1979 \mathrm{~b}$.

21. H. R. Covington, Deep Drilling Data, Raft River Geothermal Area, Idaho-Raft River Geothermal Exptoration Well No. 6, United States Geological Survey Open-File Report 79-1129, 1979c.

22. D. Goldman, D. W. Allman, and L. L. Mink, "Data Collection and Evaluation of Combined Fractured and Porous Media Flow in a Fluid-Dominated Geothermal System," National Water Well Association Conference, Oklahoma City, Oklahoma, October 1979.

23. H. R. Covington, Deep Drilling Data, Raft River Geothermal Area, Idaho-Raft River Geothermal Exploration Well, No. 2, USGS Open-File Report 77-243, $1977 \mathrm{~b}$.

24. H. R. Covington, Deep Drilling Data, Raft River Geothermal Area, Idaho-Raft River Geothermal Exploration Well, No. 1, USGS Open-File Report 77-226, 1977a.

25. H. R. Covington, Deep Drilling Data, Raft River Geothermal Area, Idaho-Raft River Geothermal Exploration Well, No. 3, United States Geological Survey Open-File Report 77-616, 1977c.

26. H. R. Covington, Deep Drilling Data, Raft River Geothermal Area, Idaho-Raft River Geothermal Exploration Well No. 3, Sidetrack C, United States Geological Survey Open-File Report 77-883, $1977 \mathrm{~d}$.

27. H. R. Covington, Deep Drilling Data, Raft River Geothermal Area, Idaho-Raft River Geothermal Exploration Well No. 4, United States Geological Survey Open-File Report 78-91, 1978.

28. H. R. Covington, Deep Drilling Data, Raft River Geothermal Area, Idaho-Raft River Geothermal Exploration Well No. 7, United States Geological Survey Open-File Report 79-1365, 1979d.

29. Republic Geothermal Inc., Maurer Engineering Inc., Vetter Research, "Raft River Well Stimulation Experiments," Geothermal Reservoir Well Stimulation Program, August 1980, DOE/AL/10563-T7.

30. D. F. Kunze, R. C. Stoker, and D. Goldman, "Heat Transfer in Formation as a Geothermal Reservoir Engineering Tool," National Heat Transfer Conference, Salt Lake City, Utah, August 14-17, 1977.

31. R. E. McAtee and C. A. Allen, "Chemical Logging, A Geothermal Technique," Geothermal Resources Council, Transactions Volume 3, September 1979, p. 423.

32. H. Schoeller, Arid Zone Hydrology, Recent Developments, UNESCO, 1959.

33. J. A. Martinez, Geophysical Logging of RRGE-1, EG\&G Idaho, Interoffice Correspondence, JAM-3-79.

34. D. W. Allman, Wellhead Temperature Surges in RRGP-5B Following Restarts After Shut-in of $5 / 27 / 79$, Other Anomalous Temperature Trends During the 21 Day Test Beginning $5 / 16 / 79$, and Temperature Reversal in Borehole Log of 11/14/78. EG\&G Idaho, Interoffice Correspondence DWA-14-79. 